
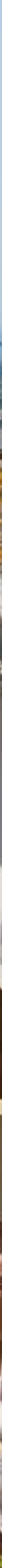


\section{La Axarquía: patrimonio cultural en una crítica encrucijada}

Esta sección ha sido elaborada, además de los firmantes, gracias a la colaboración de Aniceto Delgado Méndez, Silvia Fernández Cacho, Isabel Guzmán Guzmán, Luisa Fernanda de Juan Santos, Valle Muñoz Cruz, Lorena Ortiz Lozano, Maria Anna Papapietro, Carmen Pizarro Moreno, José $\mathrm{M}^{\mathrm{a}}$ Rodrigo Cámara
La Axarquia, montañosa, fragmentada, de difícil domesticación, pero densamente poblada y fuertemente antropizada, ha mantenido en lo esencial prácticamente invariable su modelo de ocupación y uso, a pesar de las adaptaciones practicadas por sus distintos colonizadores.

A finales de los años ochenta del siglo pasado comenzó a ponerse freno a una despoblación que venía motivada por la crisis del viñedo de finales deI XIX. La actividad vacacional, el sector servicios en general y el abandono de los cultivos tradicionales por otros que han acarreado cambios en el paisaje, en las prácticas culturales $y_{1}$ en definitiva, en los rasgos de la comarca, han paliado su abandono y se han convertido en el factor principal de su deterioro.

En esta sección se aborda el momento actual que vive la comarca, un momento de confluencia entre el modelo tradicional, conformado por una cultura secular inmersa en un proceso de decadencia, y el modelo impuesto por la modernidad, que se traduce en la degradación y la desestabilización de unos valores y un paisaje debido a las exigencias de su actividad, basada en la residencia vacacional rural. El deterioro del modelo social rural y su consecuente pérdida de identidad y de valores paisajisticos y culturales ha motivado la concienciación de los habitantes de la comarca, cuyo futuro reside en la combinación de desarrollo y recuperación territorial 


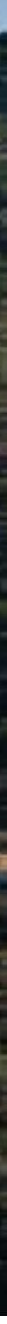

Paisaje de la carretera que discurre entre Vélez-Málaga y Arenas. Foło: Juan Carlos Cazalla, IAPH 


\section{La Axarquía, un paisaje en proceso de transformación}

Manuel Benabent F. de Córdoba, geógrafo-urbanista
La Axarquia o tierra del Este, como la denominaban los árabes, en oposición a la Hoya de Málaga, es un territorio de antigua colonización. Fenicios, romanos y árabes, por no remontarnos a la presencia humana desde el Paleolítico, se han establecido y han ocupado en mayor o menor medida su territorio, y han dejado las huellas del modo en que lo usaban y aprovechaban.

Es por ello que La Axarquia ha sido un territorio fuertemente antropizado y sujeto a grandes transformaciones para adaptarlo a las necesidades de sus diferentes ocupantes. Si fenicios y romanos estaban interesados en su litoral, en establecer colonias desde las que desarrollar una actividad comercial, o para el dominio militar del Mediterráneo y, por añadidura, extraer los recursos, los árabes tendrán una pretensión diferente, una vez asegurada la conquista su intención será permanecer, hacer de esta tierra su lugar de vida, al igual que harán los moriscos, desplazados de otras tierras, siempre acosados y finalmente expulsados y reemplazados por nuevos colonizadores.

De estas sucesivas ocupaciones, especialmente del período musulmán, ha quedado su impronta en el territorio. Su legado más visible ha sido su sistema de asentamientos, no sólo por sus características, por la tipología abigarrada y compacta de sus núcleos de población, sino también por su extraordinaria densidad, que ya el primer nomenclátor de población de la estadistica moderna presentaba en 1860 a La Axarquia como el sistema de poblamiento con mayor número de núcleos y más diseminados de Andalucia. También la disposición de este sistema de asentamientos en el territorio, su extraordinaria red de caminos y los artefactos que dan cuenta de las actividades de las que vivian nos muestran un modelo de ocupación extraordinariamente adaptado para explotar los recursos en un medio anfractuoso, dificil, muy movido, de elevadas pendientes, lomas y valles.

Comarca montañosa, fragmentada, de difícil domesticación, ha mantenido en lo esencial prácticamente invariable su modelo de ocupación y uso del territorio y tras la crisis de la filoxera de finales del XIX que acabó con su pujante actividad económica basada en el viñedo, ha permanecido hasta el último tercio del pasado siglo como un espacio olvidado y anclado en el tiempo, y mientras que buena parte de sus habitantes, ensimismados en sus dificultosas labores agrícolas, basadas en un policultivo de subsistencia que vino en buena parte a sustituir al viñedo, envejecian en torno a una actividad agrícola y ganadera secular, los más jóvenes abandonaban su tierra para buscar mejores horizontes.

La fragilidad del medio físico de La Axarquía, un medio natural limitado y marginal en términos productivos y proclive a la erosión, a lo que se le une la difícil mecanización del campo, el envejecimiento de la población rural y el predominio del minifundismo, son factores explicativos del declive del modelo agrario tradicional. Sólo el desarrollo de la actividad vacacional y en menor medida turística que tuvo lugar en su litoral a partir de los años setenta del pasado siglo, las transformaciones en regadio del valle del Guaro propiciadas por la construcción de la presa de La Viñuela a finales de los ochenta y la más reciente ocupación del interior de la comarca por nuevos habitantes, que tienen en el clima su principal atracción, pusieron freno a su paulatino abandono.

En este proceso La Axarquia se transforma, se detiene la sangría poblacional y aparecen nuevas actividades vinculadas al sector servicios, a la vez que se abandona la actividad agraria secular, en precario en buena parte de este territorio, y los cultivos tradicionales de secano se reducen de acuerdo con los avatares de la Política Agrícola Común y las demandas del mercado a favor del regadio y de los cultivos forzados. Mientras tanto, la caña de azúcar desaparece en su litoral, el aguacate y los citricos se adueñan de las vegas y se elevan mediante desmontes y aterrazamientos por las vertientes, en tanto que los frutales ganan posiciones frente al olivar. De esta manera, el viñedo y el almendro, cultivos básicos de la economía rural, terminan por ser marginales, lo que ha supuesto el abandono de toda una infraestructura de paratas y balates cuidadosa y minuciosamente construidos a lo largo de generaciones para poder cultivar en estas laderas imposibles. 

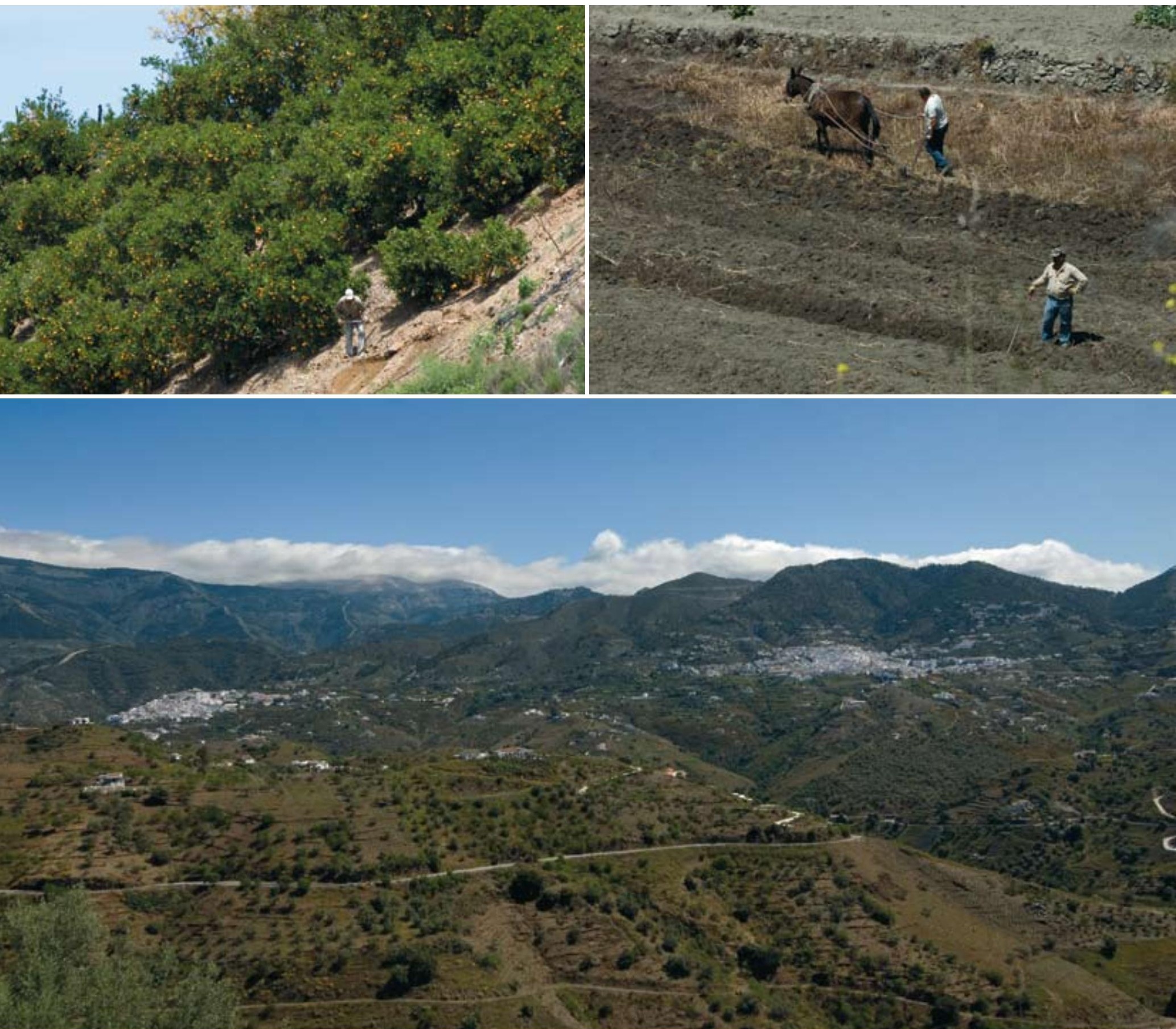

Arriba. Naranjales entre Riogordo y Comares (izquierda). Trabajos agrícolas de preparación de la huerta en la localidad de Sedella (derecha). Abajo. Paisaje que se domina desde Corumbela. Fotos: Juan Carlos Cazalla, IAPH

Las transformaciones agrícolas están teniendo una consecuencia evidente en el capital territorial de La Axarquia, en su patrimonio cultural, natural y paisajistico, en la pérdida de sus valores constitutivos y en su identidad cultural y modelado territorial, perceptibles tanto en las caracteristicas del modo de ocupación del territorio y laboreo agrícola, en los procedimientos empleados para el control de la erosión, en la propia arquitectura popular, como en las técnicas productivas empleadas.

Las consecuencias de la rápida extensión y homogeneización de los nuevos desarrollos agrícolas, con prácticas ajenas a las caracteristicas del propio territorio adecuándolo sin excesiva consideración de sus condiciones, está suponiendo no sólo la banalización del paisaje sino el abandono de prácticas culturales y con ello de las estructuras fisicas y rasgos identificadores de una actividad de siglos adaptada al medio y, por tanto, respetuosa con él.

Esta transformación territorial derivada de la agricultura se ha visto acompañada por el desarrollo urbanistico tanto en el litoral como en el interior, consecuencia del atractivo que supone este territorio y de una demanda que antes de la crisis económica en que nos encontramos estaba sustentada en la disponibilidad de suelo en buena posición respecto al borde litoral a un coste relativo inferior en relación con otras zonas costeras.

El paisaje, junto con el clima, constituye el elemento esencial de la atracción residencial y turistica que experimenta La Axarquía, pero es precisamente la belleza de este paisaje el factor principal 

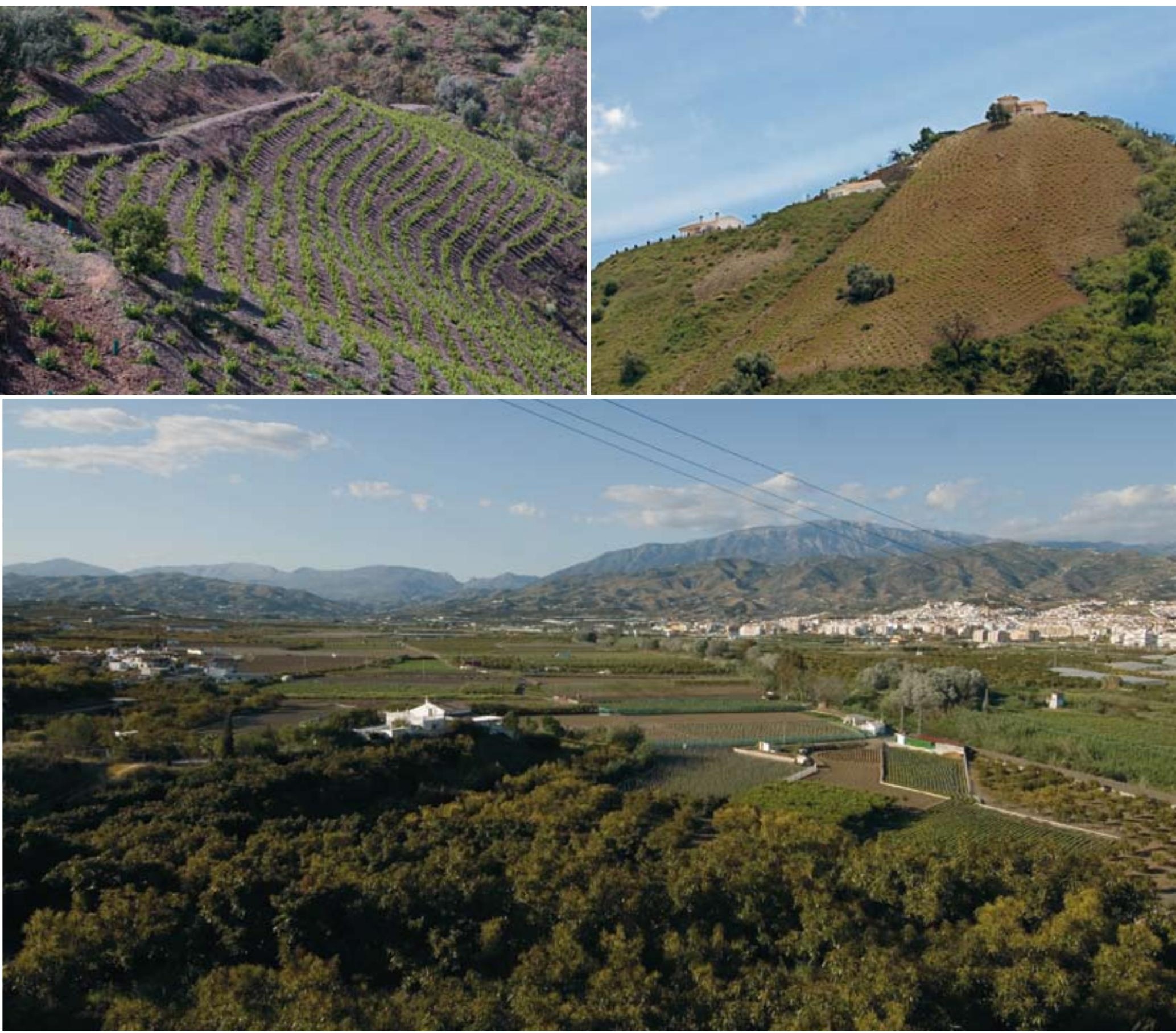

Arriba. Cultivo de vides con el sistema de paratas en Benamargosa (izquierda). Paisaje de viñedos entre Riogordo y Comares (derecha). Abajo. Paisaje que se domina desde Corumbela. Fotos: Juan Carlos Cazalla, IAPH

de su deterioro. Las amplias panorámicas, las distancias medias y largas que ofrecen los montes de tonos marrones oscuros y ocres, festoneados por los grises de las sierras calizas, impiden reconocer o más bien hacen que no pongamos atención a las vistas que ofrecen las distancias de los planos cortos y medios: las intrusiones en el paisaje que rompen tipologías tradicionales; los desmontes que desconocen los procesos erosivos y la sabiduría que encierran las paratas; la pérdida de funcionalidad de los paseros, hoy prácticamente desparecidos; los caminos de acceso a las nuevas viviendas, en pendientes imposibles que se deterioran con las primeras Iluvias; los banales muros de escolleras que sustituyen a los trabajados muros de piedras o encachados; la multiplicación de tendidos eléctricos, conducciones de abastecimiento, etc., que transmiten una sensación de ocupación caótica del territorio, de salpicado que toca todos los espacios, que se desarrolla en todas las cotas y que, en suma, suponen una reescritura del paisaje, que transforma y modifica su esencia misma de forma irreversible.

La capacidad técnica actual para transformar cualquier espacio mediante desmontes y terraplenes para ubicar las edificaciones y sus accesos y para conducir los recursos energéticos e hídricos alli donde se requieran; la posibilidad de alcanzar con los vehículos apropiados todos los lugares; el propio control de los procesos de ocupación del territorio por agentes externos, que desconocen o ignoran los emplazamientos sabiamente seleccionados de los asentamientos tradicionales, las tipologías edificatorias $y$, en suma, la cultura territorial adaptativa a la topografía y a las propias características del sustrato litológico, están dando 


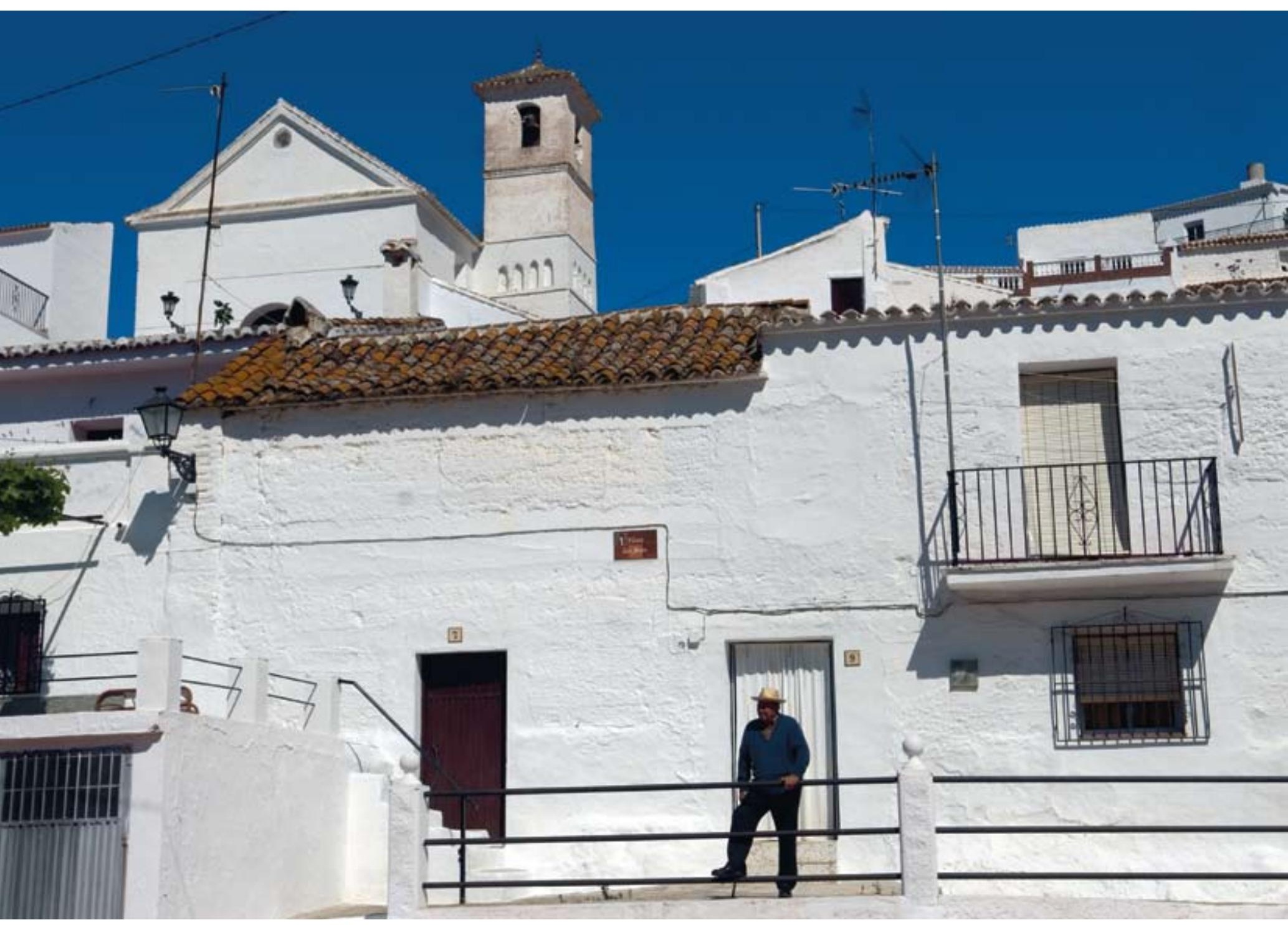

Arquitectura típica de la comarca en Daimalos. Foto: Juan Carlos Cazalla, IAPH

Las intrusiones en el paisaje, como la multiplicación de los tendidos eléctricos, suponen una transformación que modifica su esencia de forma irreversible

lugar a una rapidísima modificación del paisaje. Un paisaje que es el legado de una cultura tradicional adaptada a una orografía complicada y a unos recursos naturales limitados que, encontrando secularmente las condiciones y los medios materiales de su existencia, ha transmitido una diversa gama de contenidos formales o simbólicos y de valores culturales y estéticos propios de un ajuste equilibrado entre usos, capacidades del medio y respuestas del territorio.

Este paisaje de La Axarquía no se corresponde con el estereotipo del paisaje bello que siempre se asocia con espacios poco intervenidos y con recursos naturales bien conservados, sino que se relaciona con un territorio muy humanizado, construido palmo a palmo, y mantenido mediante una ingente labor humana de siglos siguiendo directrices de sostenibilidad y de aprovechamiento al límite de las capacidades instrumentales disponibles en cada época, lo que permite entender el modo de manejo tradicional de este territorio como una economía de uso estrechamente vinculada con su entorno, lo que ha llevado a garantizar su preservación.

La cultura tradicional popular se encuentra hoy en una critica encrucijada en la que confluyen multitud de factores y sinergias de dificil salida, entre los que destacan: el declive de estas comunidades rurales $y$, en paralelo, el abandono imparable de los espacios productivos tradicionales y la aparición de extensos territorios con apariencia de baldíos; un fuerte choque de costumbres entre lo autóctono y la modernidad, representado por actuaciones que no se adaptan a las características del paisaje, insensibles ante el incalculable legado cultural; la irracionalidad e insostenibilidad de ciertos sectores de la nueva economía agraria dirigida por premisas de viabilidad y rentabilidad a corto plazo; o la falta de atención a unos sistemas naturales (suelos, drenajes, etc.) debilitados y descontrolados, que con el tiempo se van perfilando como factores de riesgo para los propios sistemas productivos de La Axarquía. 


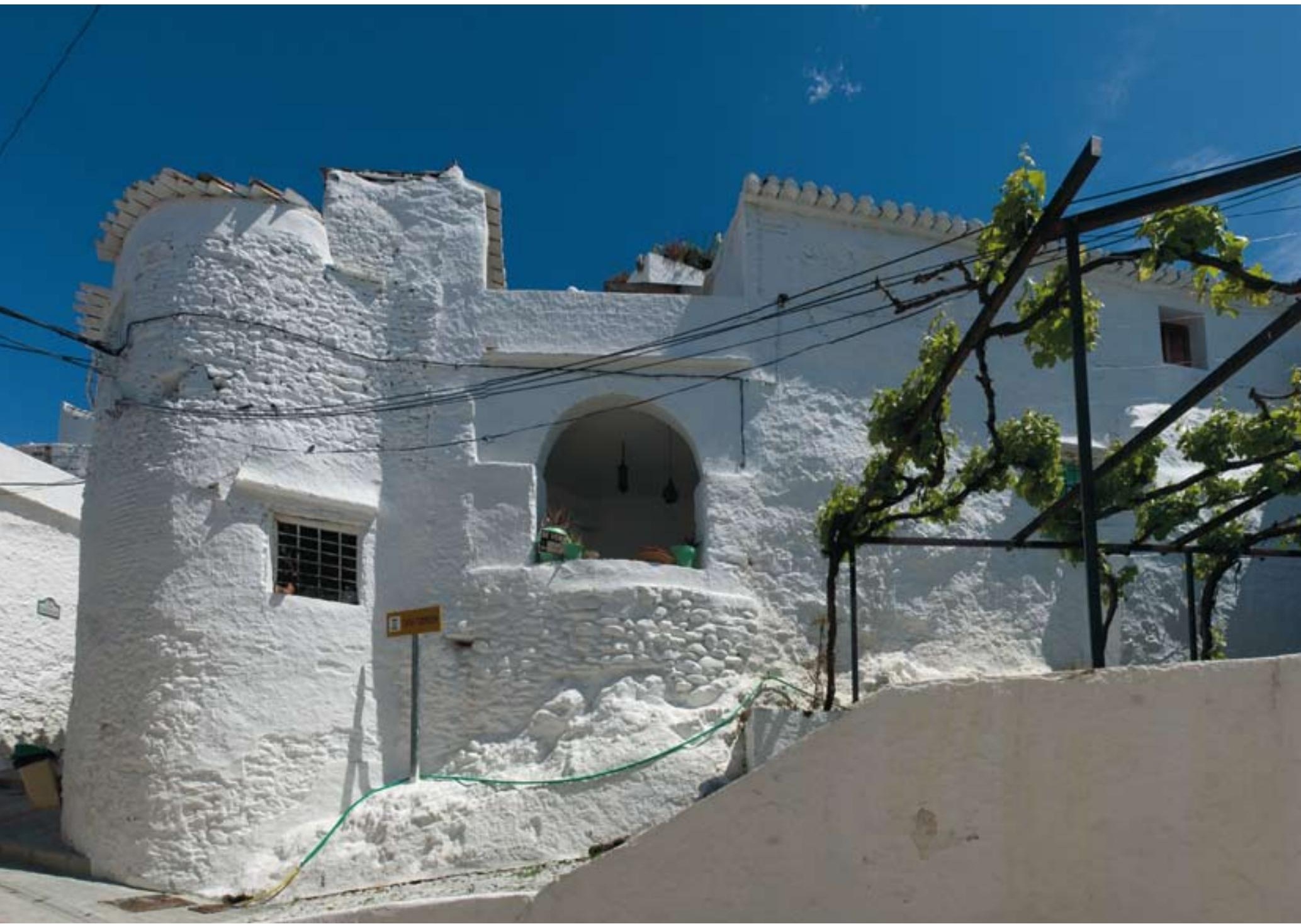

Torreón de Salares. Foto: Juan Carlos Cazalla, IAPH

En esta situación de incertidumbre y de choque cultural se está registrando un proceso de banalización y aculturación, identificable en términos de pérdida neta de valores culturales y estéticos y de sostenibilidad agrícola, y se está produciendo, bajo la forma de la residencia vacacional rural, la aparición de una nueva identidad paisajística y territorial confeccionada por un modelo de desarrollo rural regulado por la insensibilidad cultural y ambiental y por la especulación como factor de competitividad y uso del territorio.

Así, el paisaje de La Axarquía se encuentra en un momento de confluencia entre dos modelos de entenderlo: el tradicional, confeccionado por la cultura en decadencia, y el traido por la modernidad, con una importante inercia expansionista, muchas de las veces ambientalmente insostenible e insensible ante el patrimonio del entorno. El primero ha creado paisaje y generado el recurso, el segundo reconoce estas apreciables cualidades, aporta escasos valores y opera en términos de degradación y desestabilización generalizada bajo un común denominador, que estriba en la adaptación de los terrenos, cimas y laderas, a las exigencias de su actividad.
El resultado es la complejidad y dureza de las obras ejecutadas y el descuido u olvido de las inserciones paisajisticas. Fragilidad de los paisajes, abandono de la gestión por parte de sus pobladores, e intervenciones intensas y poco adaptadas a las características del medio, entre otros, son aspectos claves en la concepción de esta nueva situación en la que los criterios de productividad y competitividad se imponen sobre unos aprovechamientos de un medio natural limitado y marginal en términos productivos, así como sobre las valoraciones sociales y culturales hasta hace bien poco existentes. Hoy, el declive de la sociedad rural y el abandono del espacio agrícola tradicional dan lugar a un proceso imparable de pérdida de identidad y de valores paisajísticos y culturales, así como de homogeneización de medios, ambientes rurales y paisajes comarcales.

La toma de conciencia de esta situación por sus habitantes, la crisis económica que ha aflojado la tensión urbanistica sobre La Axarquia y el paulatino gobierno del territorio mediante la adopción de instrumentos de planificación territorial y urbanisticos suponen la esperanza de un cambio de rumbo que adecue el desarrollo necesario con la recuperación de su capital territorial. En La Axarquía ambas cuestiones están unidas. 

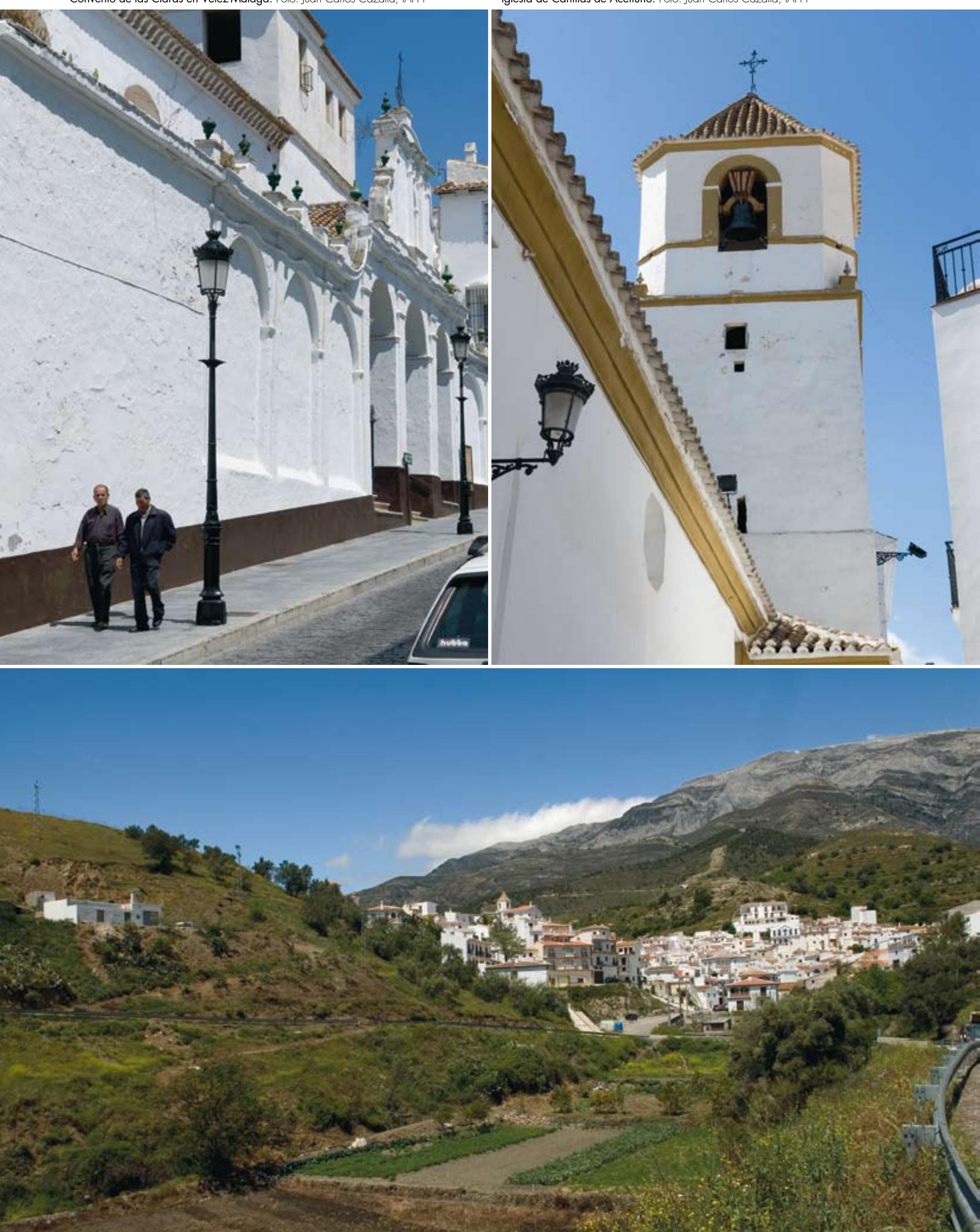


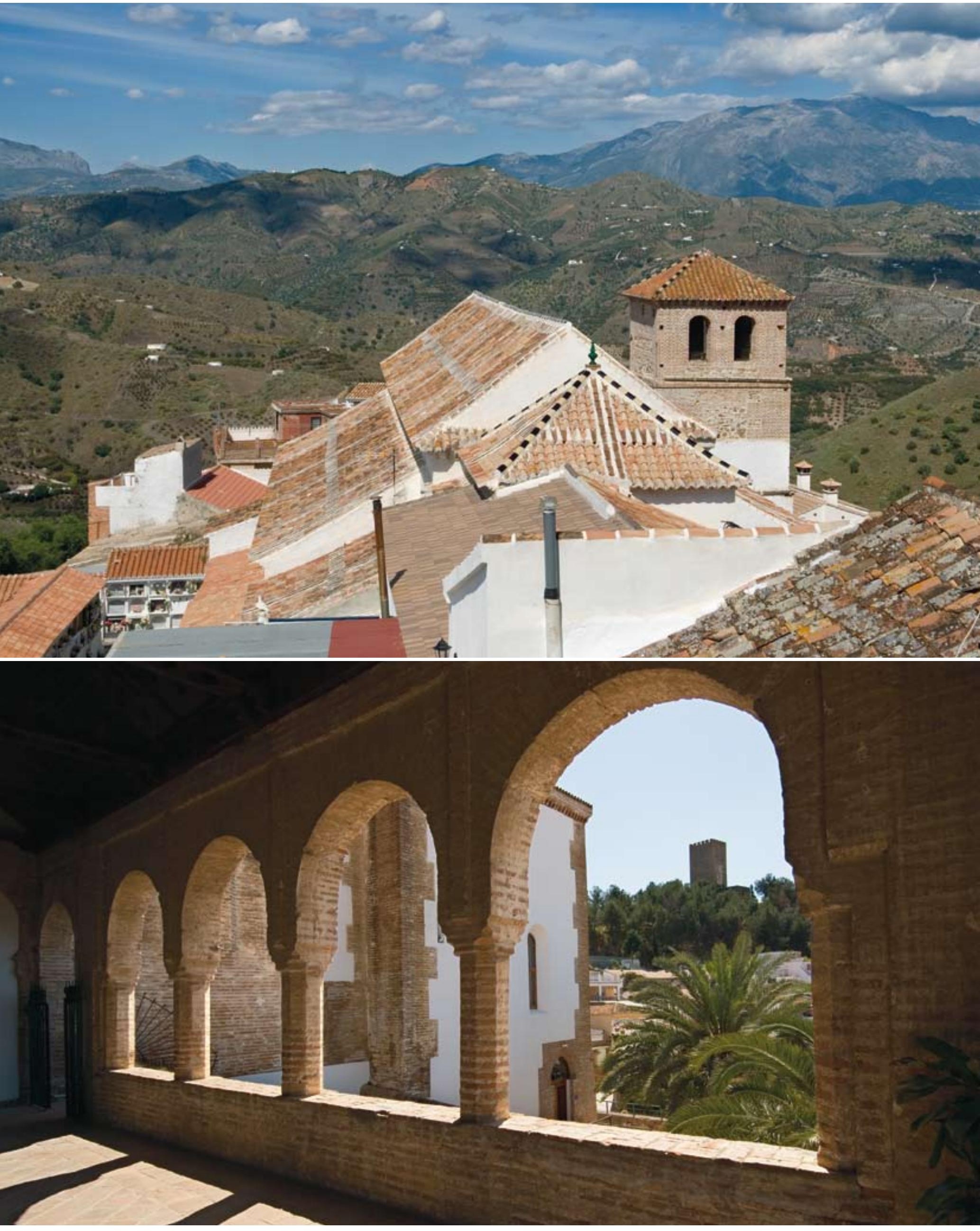

Iglesia de Santa María en Vélez-Málaga. Foto: Juan Carlos Cazalla, IAPH 


\section{Pasas y paseros: geometría paisajística en La Axarquía}

Hay en La Axarquía numerosas pendientes a la solana, situadas entre montes de pizarra a la vera de un casi inapreciable mar que se encara a una sierra imponente. En ellas, luchando por sobrevivir, rectángulos sin arar presididos por triángulos blancos dibujan parte del paisaje de la comarca. Geometría perfecta que parece contradecir la bravura de un paisaje desigual.

Lo que para un visitante son triángulos y rectángulos, para los habitantes de La Axarquía no sólo explican el paisaje sino también un sistema productivo y una cultura, la de las pasas.

Extendidas por el occidente de la comarca, hectáreas de viña intentan, hoy, alimentar a pueblos como El Borge, Almáchar, Cútar o Moclinejo con su producto secado en los omnipresentes toldos o paseros.

Sin pretender alejarnos en el tiempo, hablar de la viña y el paisaje nos remite a la primera de las epidemias que afectarian al paisaje axarqueño en el siglo XIX la filoxera. Esta no solo incidirá en la implantación de productos hasta el momento secundarios como el olivo y el almendro -modificando el propio paisaje-, sino que será determinante para la aparición de devociones y patronos que pretendian paliar las carencias de una tierra devastada. Sin embargo la vid no desaparece en su totalidad y progresivamente volverá a ganar terreno, compartido entonces con el almendro y el olivo, y ya hoy con otros productos sub-tropicales como el aguacate.

A pesar de una historia determinada por la filoxera, emigración, construcción, la elaboración de las pasas continúa siendo un elemento identitario del paisaje y sus diseñadores, los axarqueños, aunque no en el mismo grado en su economía.

Caracterizada por la especie Moscatel, la vid distribuye a lo largo del año sus tareas, antes de poder llevar a cabo la plantá en los toldos.

La primera de las fases es la retirada de los sarmientos que no valen de la cepa durante el mes de octubre. En este proceso, denominado cernillar, se dejan normalmente cuatro brazos a partir de los cuales crecerá el sarmiento de donde debe salir el racimo. Posteriormente, a partir de la Purísima (8 de diciembre) es cuando se enfraga. Esta tarea implica arrancar lo que crece alrededor de la cepa a la vez que se remueve la tierra. Estas labores que se realizan sin la ayuda de ningún animal y son llevadas a cabo por los hombres dejan la vid preparada hasta finales de marzo-principios de abril, periodo en el que se vuelven a trabajar.

Las pendientes y una parcelación lejana a los latifundios de campiña, heredada de una repoblación tardia, dificultan el trabajo con las bestias y presenta una tierra de pequeñas parcelas donde el ser humano continúa teniendo que hacer frente a las tareas agrícolas a lomos de su costal.

La llegada de la primavera, y después de la temporada de la aceituna, da paso al proceso de binar, es decir, el acto de remover la tierra o cavar. Es un proceso más superficial que sirve como sistema natural de sulfatar la tierra. Tal proceso puede durar hasta principios de mayo cuando se esparce azufre por encima de la cepa

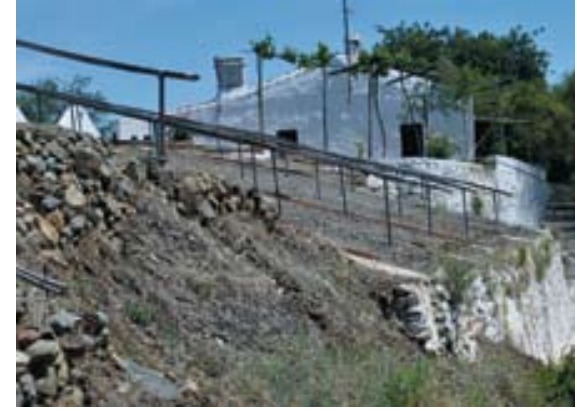

Pasero y lagar en Almáchar. Foto: Marc Ballester Torrents

para evitar que le caiga ceniza (proteger de plagas naturales). Una vez azufrao, se lleva a cabo a partir del 10 de mayo el proceso de espuntar. En dicho proceso se corta la moquilla, punta del sarmiento, dejando dos yemas (una más cercana al brazo y otra por arriba) de donde crecerá el racimo. Este proceso permitirá concentrar el crecimiento de un racimo por sarmiento (dando más calidad a la uva) y proteger el racimo del sol, evitando así que se abra la cepa.

Determinado el crecimiento de la cepa en algunos casos se vuelve a realizar el azufrao (siempre antes de que crezca el racimo porque si no lo quemaría) que lleva a realizar el tapado a partir del mes de junio, que es cuando el racimo ya está creciendo y podría ser dañado por el calor. El tapado puede llevarse a cabo volteando la cepa con algún sarmiento de la misma o cubriéndola con hierbas. Entrado el verano las tareas en la viña se centran en el cuidado y preparación del pasero o toldo.

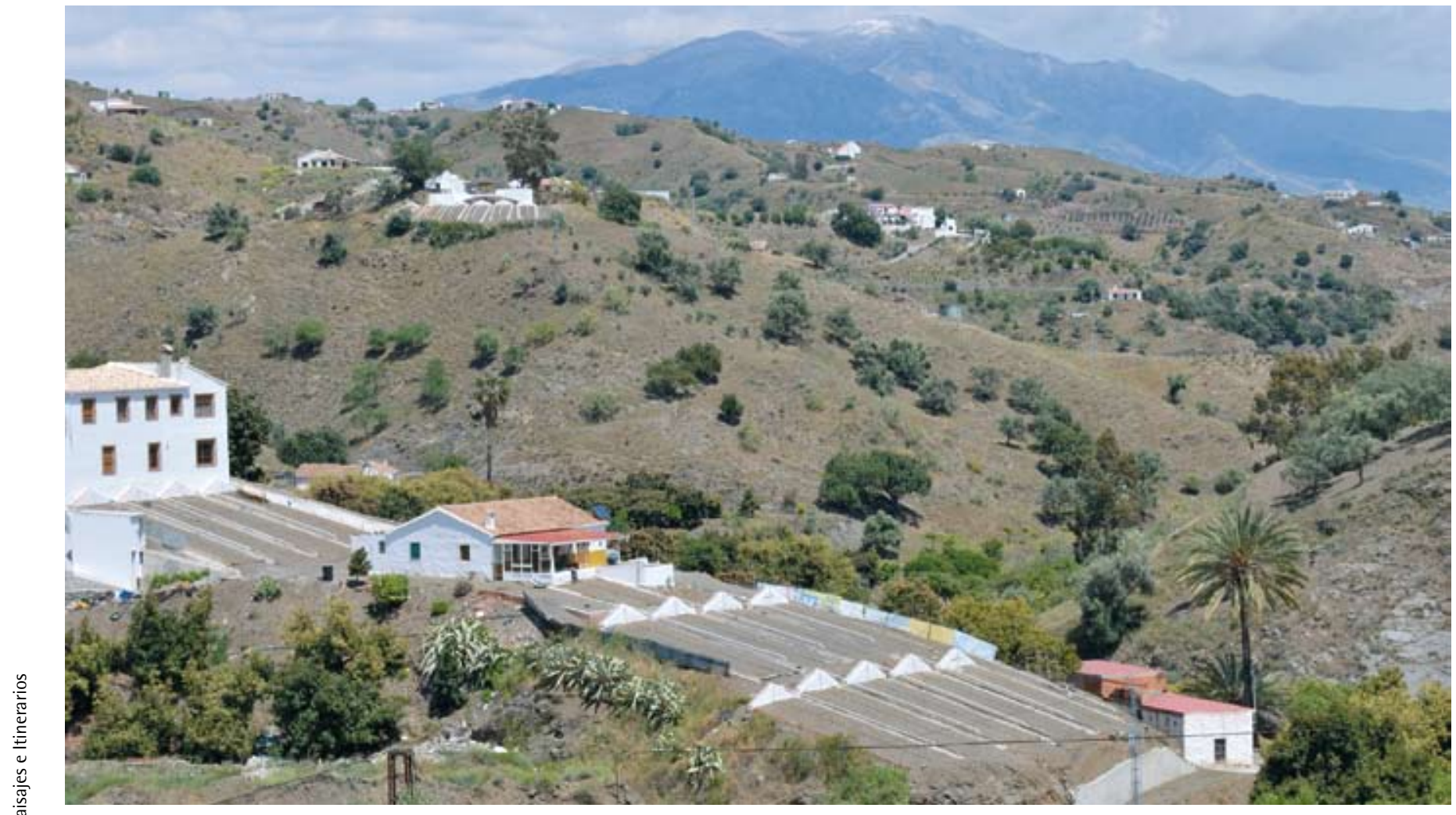

Paisaje pasero en La Axarquía con la Sierra Tejeda-Almijara de fondo. Foto: Marc Ballester Torrents 
A lo largo del año, los paseros son espacios abandonados donde se deja crecer la hierba y se amarran las bestias, así que hay que proceder a limpiarlos y prepararlos para la plantá.

Es a principios de agosto cuando empieza la vendimia. Este trabajo que tradicionalmente implicaba a toda la familia sin distinción de géneros y edades hoy se pone en entredicho debido al cambio en la propia sociedad local. La necesidad de contratación es lo que hace cada vez más difícil de sostener la producción de vid $y_{1}$ en consecuencia, de la pasa. Este cambio progresivo rompe con unas formas que se caracterizaban por el traslado al campo de toda la unidad familiar durante el mes de agosto y principios de septiembre, con la noche de las candelas el 7 y 8 del mismo mes.

Es en este momento cuando empieza el trabajo de la pasa. La elaboración de la pasa de uva moscatel en La Axarquía se caracteriza por el secado de la uva al sol en los paseros o toldos. Una elaboración que se realiza manualmente en sus diferentes fases, plantá, volteo, recogida o levantá, picar y criba.

El pasero o toldo es una porción de tierra rectangular de entre 4 metros de ancho por unos 12 de largo que está presidida por un muro de forma triangular. Del vértice superior del muro salen unas cañas llamadas combrero que avanzan hasta el final del rectángulo dejando el toldo dividido en dos partes iguales llamadas patas. El combrero se apoya en los pinganillos o palos clavados en la tierra hasta llegar al fondo, parte inferior del toldo. En los laterales, a medio metro del límite del pasero, está la calle donde se sitúan unas estacas para agarrar el lienzo que se pone para cubrir de la lluvia. Están ubicadas a un cuarto del suelo para evitar que el agua caiga cerca del pasero y facilitar el paso de las personas.

Los paseros se ubican en las laderas al solano siendo las zonas de umbría las menos propensas a su instalación por ser más húmedas al tocar menos el sol, hecho que alarga el proceso de secado de la pasa.

La plantá recién recogida la uva se hace por racimos poniendo los de más calidad (por el tamaño) en el centro y progresivamente alrededor los que tienen las uvas más pequeñas. El tiempo de cochura (o secado en el pasero), dependiendo del tiempo y de si está en solana o umbria, es de unos veinte dias. El orden coincide con las diferentes clases de pasa. Reviso (mayor tamaño y calidad), reviso medio, aseao, corriente y escombro. Tras el proceso manual de picar -cortar la pasa del racimo dejando el rabillo, ya que si no la pasa se pudre-, se selecciona la pasa en la criba. No hace tantos años que en el proceso de picary cribar mujeres y niños asumian el protagonismo.

Finalmente las pasas se colocan en cajas de madera, las catites o chatos, cajas con capacidad para $10 \mathrm{~kg}$ de pasas en racimo de diferente calidad, o las guarritos, cajas con el dibujo de las propias pasas. Un oficio, un manjar que durante años ha definido cultura y que parece pervivir exclusivamente en un paisaje silencioso a la espera de una nueva epidemia, una epidemia hoy llamada rentabilidad.

\section{Marc Ballester Torrents} Antropólogo

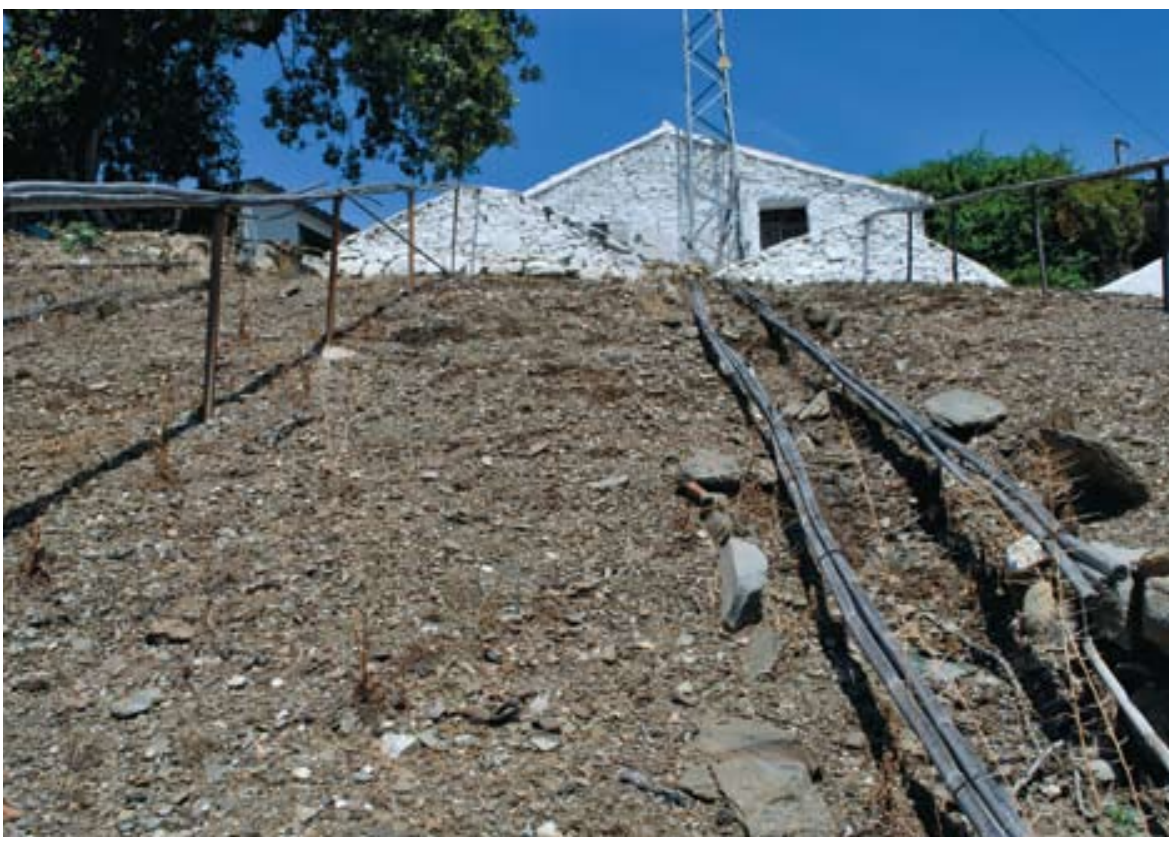

Pasero en Almáchar. Foto: Marc Ballester Torrents

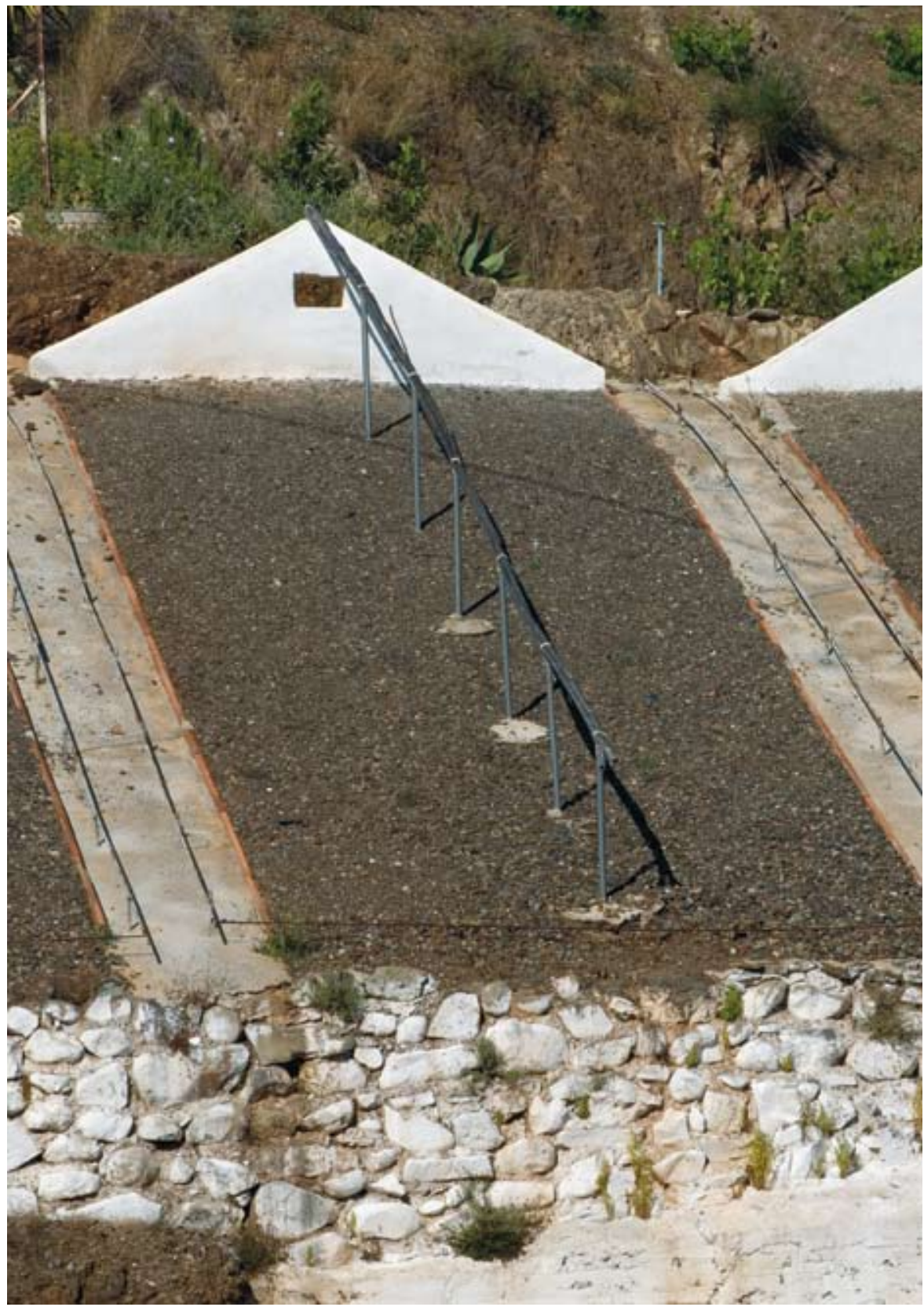

Pasero en Almáchar. Foto: Juan Carlos Cazalla, IAPH 


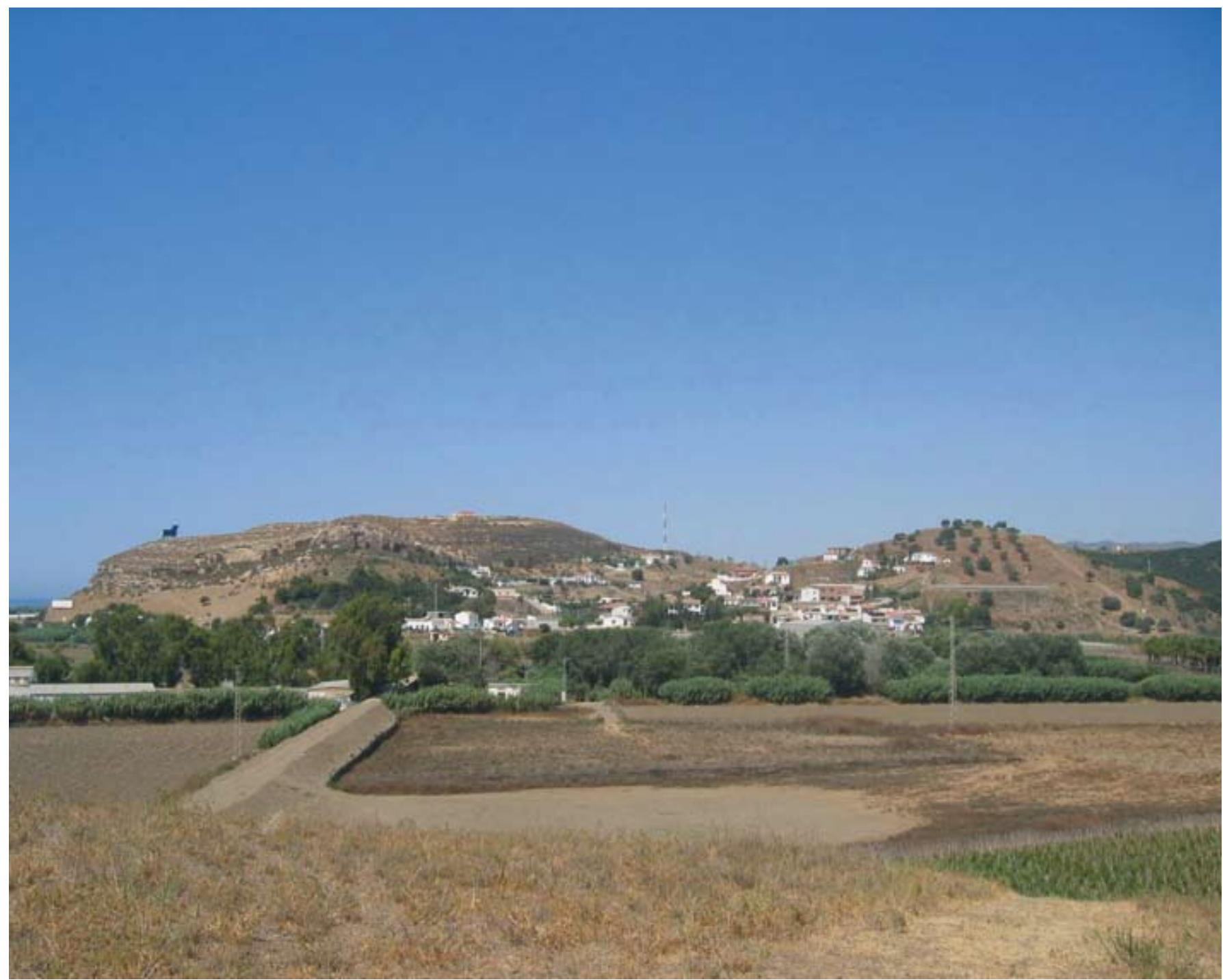

Playa Fenicia, proyecto municipal de Vélez-Málaga con la colaboración de la Consejería de Cultura para la puesta en valor de los yacimientos fenicios de la zona. Foto: Emilio Martín Córdoba 


\section{Asentamientos fenicios en la costa oriental y adecuación del cerro del Villar en la desembocadura del río Guadalhorce}

Manuel Corrales Aguilar. Delegación Provincial de Málaga, Consejería de Cultura de la Junta de Andalucía
La expansión comercial y colonizadora fenicia hacia el Mediterráneo Occidental y el Atlántico ha dejado una profunda huella en las costas de la actual provincia de Málaga, especialmente en la zona de La Axarquía. El alto número de yacimientos alli documentados, excavados por el Instituto Arqueológico Alemán, ha situado este territorio entre los mejores conocidos por la investigación científica internacional. Si a ello le sumamos los datos aportados por las intervenciones en la ciudad de Málaga (la Malaka fenicio-púnica) y en el Cerro del Villar, la actual provincia malagueña se convierte en un referente ineludible para el conocimiento de la presencia fenicia en 0ccidente y de la transformación de sus paisajes.

El esfuerzo de las administraciones locales y autonómicas por difundir este rico patrimonio se concretan a través de la futura Ruta fenicia y sus centros de interpretación: Playa Fenicia (VélezMálaga) y Cerro del Villar (Málaga).

\section{FENICIOS}

Los griegos aplicaron en diferentes pasajes de sus obras el nombre de fenicios (phoinikes) a las gentes descendientes del trono semita que habian Ilegado a la zona costera del norte de Canaán poco antes del año 3000 a. de C. Fenicio equivaldría en su interpretación más sencilla a hombre de tez roja o también a hombre de la púrpura.

Uno de los acontecimientos históricos más trascendentes lo caracteriza la expansión comercial y colonizadora fenicia hacia el Mediterráneo centro-occidental, además del Estrecho de Gibraltar, las fachadas atlánticas de Andalucía, Portugal y Marruecos. Los primeros pasos en este proceso podríamos situarlos en el siglo XI a. de C. en la isla de Chipre, de gran riqueza en cobre. La presencia en Chipre cristaliza a fines del siglo IX a. de C. con la fundación de la colonia Kitión. Más tarde, en el siglo VIII a. de C., surgirán las primeras factorias y colonias fenicias occidentales, precedidas probablemente por Cartago (814/ 813 a. de C.).
En realidad sabemos muy poco de los colonizadores y de sus formas de organización socio-política. El área de ocupación de las colonias fenicias es bastante reducida: lugares pequeños con gran densidad de edificios y viviendas que se adaptan al espacio.

Durante un tiempo, y recurriendo al modelo griego, se pensó que el proceso de colonización se basaba en una dispersión de población y la ocupación de tierras agrícolas; sin embargo, en el Cerro del ViIlar, su registro arqueológico, los análisis paleobótanicos y de suelos, el registro faunístico y los diagramas polínicos demuestran que los habitantes de la colonia se limitaron a consumir recursos agrícolas y ganaderos producidos por otros. Lo que nos lleva a pensar que estos centros tienen carácter económico y comercial, aunque podría darse un fenómeno multicasual que generara el proceso colonizador.

Las colonias estarían dominadas por comunidades de mercaderes con un estatus social elevado, quizá una burguesía mercantil especializada, pudiendo darse el caso de que estas pequeñas colonias fueran fundadas por asociaciones, consorcios o firmas mercantiles. Así parece indicarlo el contenido de las tumbas de cámara de Trayamar, verdaderos panteones familiares y colectivos que se reabrian periódicamente para acoger a los miembros de un mismo grupo social; se tratarian de mercaderes que viajan con sus juegos de pesas a Occidente y que se instalan en lugares con excelentes condiciones portuarias así como de fácil acceso al interior, a Tartessos.

Los fenicios no encontraron las costas vacías; conocemos la existencia de poblados del Bronce Final muy próximos a los asentamientos, como el de la plaza de San Pablo en Málaga. La distribución de las colonias fenicias demuestra que el comercio oriental se orientó fundamentalmente hacia aquellos centros que dominaban los principales puntos estratégicos y vías de comunicación naval y terrestre y que habian formado parte del comercio internacional del Bronce Final. Poblados como el de San Pablo sugieren no sólo la existencia de acuerdos con los jefes indigenas de la zona, sino la intrusión del comercio fenicio en las mismas estructuras organizativas de las comunidades indígenas, con todas sus aplicaciones de indole social y económico. 


\section{LA COSTA ORIENTAL DE MÁLAGA COMO PAISAJE MÍTICO}

La bahía de Málaga y la costa de La Axarquia reunian los requisitos fundamentales para convertirse en un lugar deseado. Sus caracteristicas físicas y su situación geográfica la convertían en un enclave básico para el control del tráfico marítimo y del paso al continente africano.

Las caracteristicas de los territorios y por ende de los paisajes son percibidas de muy distintas formas y provocan emociones, sentimientos, sensaciones en virtud de las experiencias individuales y colectivas asociadas a la cultura y al grupo de pertenencia. Asi, en tanto que los paisajes entran por los sentidos, acaban siendo depositarios de sentimientos y valores. Sabemos, no obstante, que el paisaje de entonces no era como el actual: la línea de costa ha cambiado retirándose de los asentamientos fenicios a los que se llegaba navegando, y existian bosques de arbustos e indicios de bosque de monte bajo, entre arbustos de dos o más metros de altura, con pinos carrasco, cipreses, encinas y alcornoques, con especies de animales salvajes como el ciervo, el corzo, el jabali y el gato montés.

Una serie de textos literarios de la Antigüedad hacen referencia a una ciudad de nombre Mainake que habría sido la colonia más occidental de cuantas los griegos fundaron en el Mediterráneo. Quizá el más antiguo sea el documento que sirve de base al poema latino Ora Maritima de Rufo Festo Avieno, donde podemos leer: cerca de éstos, además vienen inmediatamente el monte Barbetio y el río Malaca, con la ciudad del mismo nombre, Ilamada antiguamente Menace. Alli delante de la ciudad, hay una isla del dominio de los tartessios, consagrada a Noctiluca desde tiempo atrás por los habitantes del lugar. Cerca de la isla hay una laguna y un puerto seguro. La ciudad de Menace queda más arriba (Avieno, Ora Maritima, vv. 426-431). También en esta Ora Maritima (vvs. 178-182) se nombra un camino interior por el que desde Mainake se llegaba a Tartessos en la zona del Bajo Guadalquivir en cinco dias de marcha.
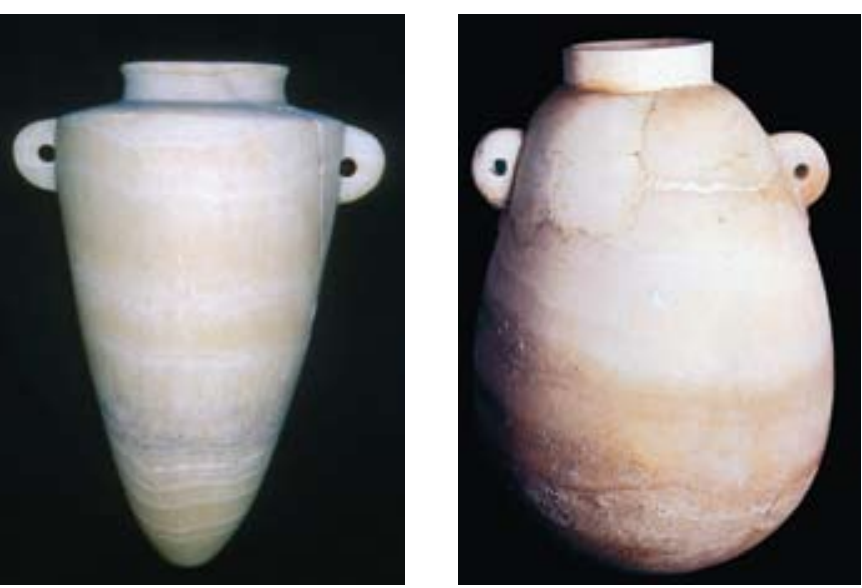

Urnas de alabastro. Fuente: Archivo Delegación Provincial de Cultura de Málaga. Consejería de Cultura
Otro texto clave, el siguiente en el tiempo, será el periplo llamado Pseudo-Escimno quien complementa la Ora Marítima con la noticia atribuida a Eforo, autor del siglo IV a. de C. según la cual esta ciudad de Mainake era una fundación de los massaliotas (griegos de Massalia, actual Marsella) y que de todas las ciudades griegas que se fundaron en el Mediterráneo, ésta era la que ocupaba una posición más extrema (Ps. Escimno, 146-149).

También, utilizando fuentes más antiguas, el geógrafo griego Estrabón afirmaba, a comienzos de nuestra era, que algunos pensaban en su época que Malaka ( $m / k$ ) es la misma que Mainake, de la que sabemos por tradición que es la última de las ciudades foceas hacia Poniente, pero no lo es. Pues Mainake, más alejada de Calpe, está destruida hasta los cimientos, aunque conserva vestigios de una ciudad griega, en tanto que Malaka, más cercana, es de configuración fenicia (Estrabón, III 4.2).

Otras fuentes mencionan una ciudad cuyo nombre recuerda al de Mainake; Hecateo en un texto recogido por Esteban de Bizancio cita la ciudad de Mainóbora que sería la misma Maenoba de Pomponio Mela, la Maenuba de Plinio, y la Mainoba que aparece como Menova en el Itinerario Antonino y que se localiza con bastante seguridad hacia la desembocadura del río Vélez.

Muchos investigadores han intentado a lo largo de varias generaciones encontrar el lugar exacto donde se ocultan estas ruinas perdidas. Será el historiador y arqueólogo Adolf Schulten (1870-1960) quien, a partir de 1931, siguiendo estos textos y especialmente el nombre de Mainobora, localidad indígena, relacione La Axarquía y más concretamente el Cerro del Peñón de Almayate, cerca del Torre del Mar, como entorno geográfico especifico donde buscar y encontrar Mainake, la ciudad mítica fundada por los griegos.

No la encontró; sin embargo, la repercusión de los trabajos de Schulten fue considerable y motivó el interés de otros arqueólogos, como sus compatriotas H. G. Niemeyer y H. Schubart quienes en 1961 recorrieron y estudiaron el Cerro del Mar, el Cerro del Peñón y el Cortijo de Los Toscanos. En superficie encontraron restos cerámicos de varias épocas como los fragmentos de dos kotylai protocorintias y bordes de ánforas fenicias. A raiz de aquellos resultados empezó, a partir de 1964, por encargo del Instituto Arqueológico Alemán, una larga y fructífera serie de excavaciones en el cortijo Los Toscanos bajo la dirección de los profesores M. Pellicer, H.G. Niemeyer y H. Schubart. La importancia de estas excavaciones reside en haber descubierto el primer asentamiento fenicio de la Península lbérica con una estratigrafía intacta de los siglos VIII-VI a. de C.

Se iniciaba así, junto al descubrimiento de la necrópolis de Almuñécar por M. Pellicer en 1962 y el comienzo de las excavaciones de Antonio Arribas en la desembocadura del río Guadalhorce y en la necrópolis de las sombras en Frigiliana, la arqueología fenicia en la Península Ibérica 


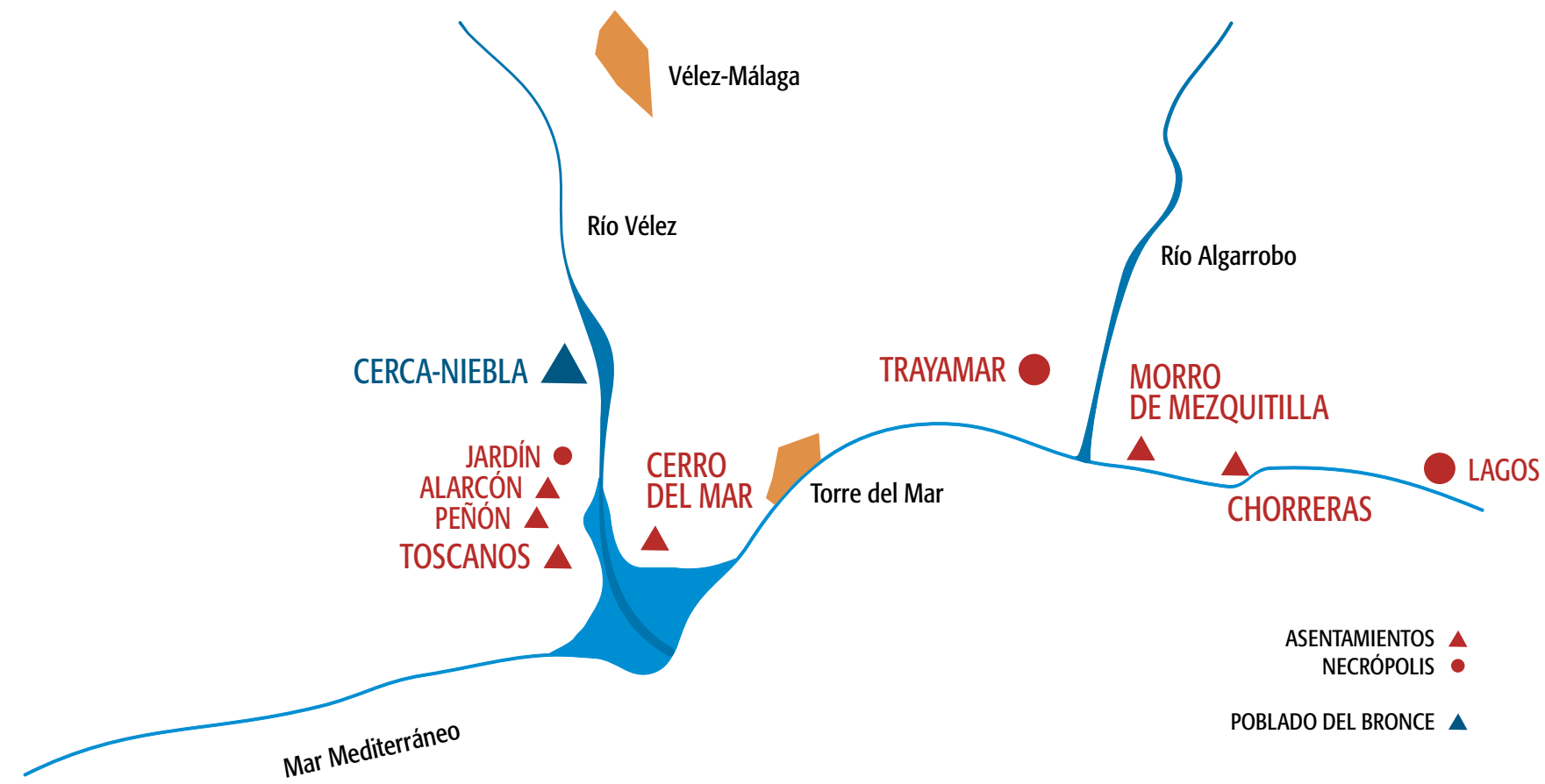

Poblados, necrópolis fenicias y asentamientos del bronce en las desembocaduras de los ríos Vélez y Algarrobo. Mapa: Jorge Dragón

\section{Lugares para percibir}

Desde los años 1964 hasta 1987, el Instituto Arqueológico Alemán de Madrid llevó a cabo trece campañas de excavación, bajo la dirección de H. G. Niemeyer y H. Schubart, dentro del programa de investigación dedicado a la arqueología fenicia en la zona de las desembocaduras de los ríos Vélez y Algarrobo, lo que ha posibilitado que estos territorios sean referencia obligada para la investigación y conocimiento sobre los fenicios y su proceso de colonización.

La fase colonial propiamente dicha de la expansión fenicia occidental ha sido objeto de numerosos estudios. Las dataciones de Toscanos fueron las primeras disponibles para fechar la presencia fenicia en la Península lbérica y por extensión en el Mediterráneo Occidental desde 1965, mientras que las dataciones de Morro de Mezquitilla han aportado las cronologías más antiguas de los fenicios en Occidente hasta los recientes hallazgos de Huelva.

Entre las cerámicas más antiguas de las colonias de la Península Ibérica se encuentran un par de platos- cuencos de Fine Ware, varios platos comunes tipo 9 Tiro y algunas ánforas Sagona, que pertenecen singularmente al Castillo de Doña Blanca y a Morro de Mezquitilla. En nuestro caso, estos platos-cuencos se asociaban a platos de producción occidental inspirada en el tipo 3 ó 2 de Tiro lo que parece llevarnos a mediados o segunda mitad del siglo VIII a. de C. para el inicio de la colonización en Morro de Mezquitilla. No obstante, según Volker Pingel, las dataciones radiocarbónicas apoyarian un comienzo de la colonización antes del temprano siglo VIII a. de C. Por su parte, Mederos pone en relación la fase
B1 de Morro con la Tiro 4 lo que nos lleva a 800-775 a. de C. y con seguridad la fase B2 o B1 con Tiro 3, es decir, 775-773 a. de C. Estas, pues, son las fechas que se barajan para el asentamiento fenicio más antiguo en nuestras costas malagueñas y uno de los más antiguos de Occidente.

La existencia de un puerto natural fue condición previa decisiva para la elección de este emplazamiento, al igual que en el caso de los demás asentamientos fenicios. Este puerto natural consistía en una pequeña bahía, situada a tan sólo $400 \mathrm{~m}$ al oeste de la cima de Morro, en la que, en su día, desembocaba el río Algarrobo. Los recién llegados encontraron una colina situada en la misma costa desembarcando en una pequeña cala, hoy situada algo tierra adentro en la desembocadura del río, y se asentaron en la cima, asi como probablemente en la ladera occidental que ascendía desde la bahía.

Las excavaciones en el yacimiento de Morro de Mezquitilla se llevaron a cabo en 1967, 1976, 1981 y 1982. El yacimiento conoce tres grandes momentos históricos, iniciándose con una ocupación en la Edad del Cobre, denominada fase A, que está relacionada con unos hornos de fundición de hierro. En la transición del siglo IX al VIII a. de C. y sin continuidad de ocupación en el tiempo con la etapa anterior, se produce la fundación del asentamiento fenicio, que se le reconoce con la letra $B$; mientras que el tercer periodo, relacionado con las construcciones púnicas y romanas, se le asigna con la letra C. El periodo fenicio quedó subdividido por una fase de transición $A$ / B1, tres fases consecutivas B1, B2, B3. Nos ofrece un sorprendente urbanismo con espacios domésticos de habitaciones compartimentadas y adaptadas a calles de trazado regular. 


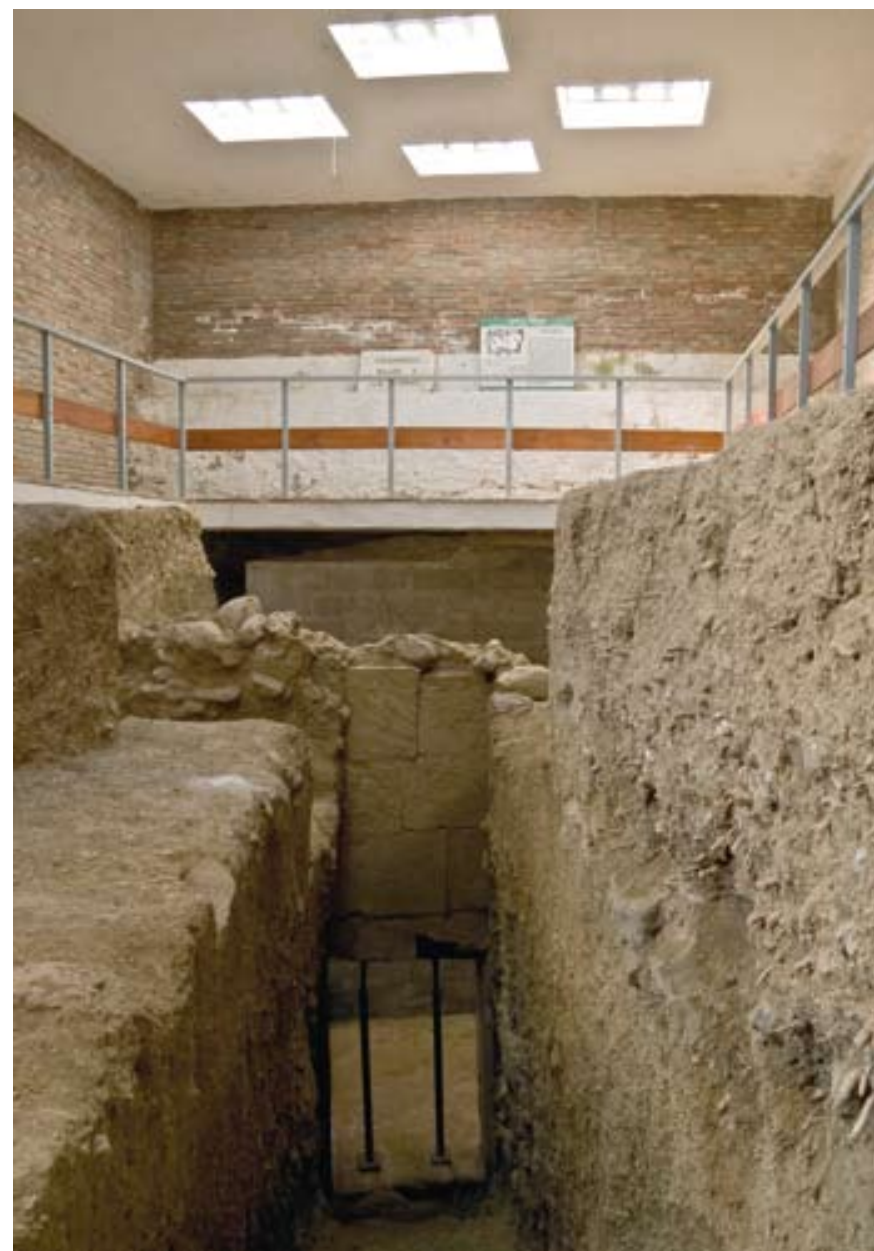

Hipogeo de la necrópolis de Trayamar, en la desembocadura del río Algarrobo. Foto: Jorge Dragón

De igual manera que las bahias con desembarcaderos en sus playas servían de puerto en esta época y, a su vez eran condición previa para establecer un asentamiento, encontrándose siempre al pie de los yacimientos fenicios, la necrópolis correspondiente se hallan casi siempre al otro lado de la bahía o, al menos, al otro lado de la depresión de un valle, según el patrón de asentamiento que conocemos. La necrópolis de Trayamar se encontraba en la desembocadura del río Algarrobo, en su margen occidental y visible desde el Morro de Mezquitilla al que pertenecía. De ella se conocen sólo cinco hipogeos, dos fueron excavados y otros tres destruidos. La forma de estos hipogeos y la composición de los ajuares funerarios confirman el carácter foráneo de las personas enterradas aquí, pertenecientes a una clase social elevada de la población fenicia, quizá miembros de un grupo de familias de mercaderes asentadas aqui desde hacia tres o cuatro generaciones. Las urnas de alabastro y las joyas de oro halladas en las tumbas dan testimonio de las extensas relaciones comerciales existentes en esta época.

Chorreras, a unos $800 \mathrm{~m}$ al este de Morro de Mezquitilla, ocupa una extensión de unas tres hectáreas sobre los espigones rocosos, y se excavó bajo la dirección de Gran Aymerich y Aubet, en 1973, y de Aubet y Schubart, en 1974. Dado que no posee ningún puerto natural, hay que partir de la base de que Chorreras estaba relacionado con la desembocadura del río Algarrobo y por ende con el asentamiento del Morro de Mezquitilla. Chorreras se funda con posterioridad a Morro, a mediados del VIII a. de C. o

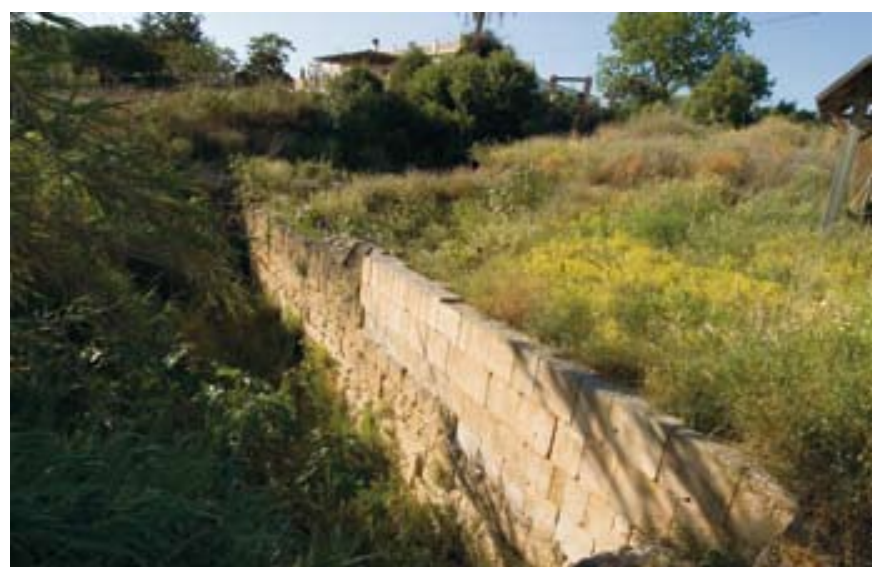

Yacimiento del cortijo de Los Toscanos. Foto: Juan Carlos Cazalla, IAPH

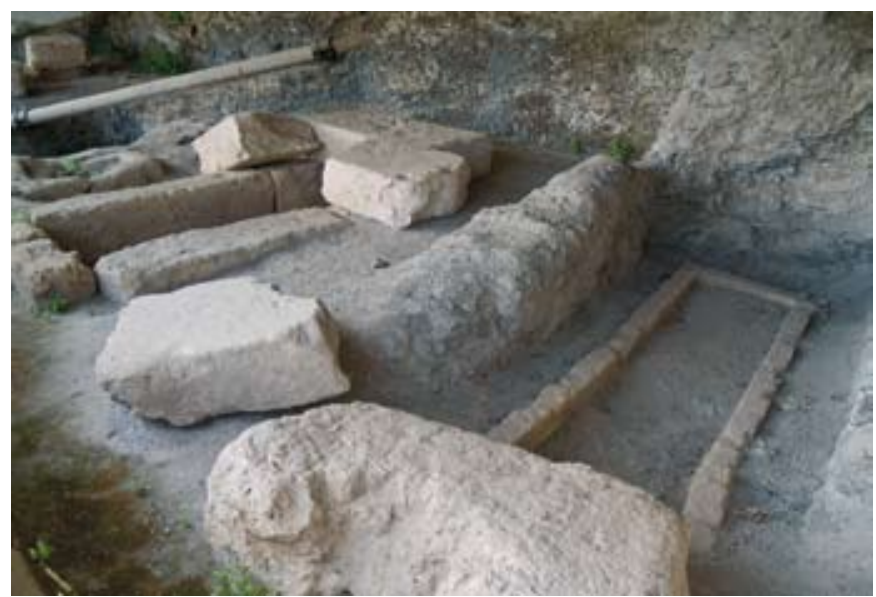

Necrópolis de Jardín. Foto: Jorge Dragón

poco después, y se abandona ya a principios del VII a. de C. Es un hábitat que se organiza con la creación de una serie de viviendas agrupadas a partir de una calle adaptada al terreno que se convierte en el eje de distribución; su abandono hay que entenderlo como un reajuste ocupacional en el territorio, debido a la mejor proyección industrial, comercial y económica de Toscanos.

Toscanos fue fundado al poco tiempo de la creación de Chorreras, entre los años 740-30 a. de C. Las excavaciones realizadas en ocho campañas entre 1964-1984 fueron las primeras en un asentamiento fenicio de la Península lbérica y permitieron formar una idea de la estructura urbanística y la secuencia estratigráfica de las fases más antiguas. Aparecieron casas, así como construcciones más humildes o cabañas, y también un edificio más importante, el edificio C, probablemente un depósito o almacén, que formaría parte de la primera área urbanizada. Toscanos, uno de los yacimientos fenicios con mayor extensión excavado en la Península lbérica, es un destacado centro de los siglos VIII-VII a. de C. del que se distinguen un total de cinco etapas ocupacionales desde el momento de su ocupación hasta su abandono, a mediados del VI a. de C.: Toscanos I, era un primer asentamiento limitado con escasa población, pero que cuenta ya con algunas casas aisladas que delimitan calles. Toscanos II presenta un importante aumento poblacional, posiblemente con la llegada de nuevos colonos; a esta fase pertenece también el sistema defensivo que rodea la colina, consistente en un foso. Las casas presentan zócalos de piedras y muros de adobe. Sobre el 700 
a. de C. comienza Toscanos III, periodo de máximo esplendor con mayor desarrollo urbano e industrial. La denominada Toscanos IV comienza en la segunda mitad del VII a. de C., en ella se registra una expansión hasta llegar a un tamaño entre 12 y 15 hectáreas y una población estimada entre mil y mil quinientas personas. En esa época se dataría un nuevo recinto amurallado que englobaría todo el centro urbano e industrial y del que quedan importantes restos en Cerro de Alarcón. En los inicios del siglo VI a. de C. daría comienzo la fase Toscanos $V$, en la que se produce una reordenación del espacio en el asentamiento. En torno al 550 a. de C. por causa aún no aclarada se abandona este lugar.

Desde que se comenzaron las excavaciones en Toscanos, se hizo necesario conocer la trayectoria de las líneas de la costa en aqueIlos tiempos, en especial la localización de las ensenadas portuarias. Los trabajos geológicos realizados a partir de 1982 por el equipo de la Universidad de Kiel, bajo la dirección de Schulz, probaron que en época fenicia el mar llegaba hasta los pies del asentamiento de Toscanos, penetrando la ensenada hasta unos $7 \mathrm{~km}$ al interior pudiendo las embarcaciones llegar con facilidad hasta sus rebordes rocosos. Esta proximidad del mar también se dio en los tiempos romanos, incluso es conocido que los barcos castellanos pudieron igualmente navegar durante la toma de Vélez-Málaga. Será por tanto a partir del siglo XV cuando se produzca la aceleración del proceso formativo de la Ilanura aluvial del Bajo Vélez que hoy conocemos.

Las necrópolis de Toscanos, que son de incineración y fechadas a lo largo del siglo VII a. de $\mathrm{C}$., se localizan en las laderas del cercano Cerro del Peñón y al otro lado del río, tanto en Cerro del Mar como en el lugar Ilamado Casa de la Viña. De esta última necrópolis arcaica, algunos de cuyos materiales ya fueron descubiertos en el siglo XVIII, se han localizado 25 tumbas de tipo pozo de unos dos metros de profundidad que se fechan entre los siglos VIII y finales del VII a. de C. que tienen nichos laterales para colocar urnas de alabastro en donde se depositaban las cenizas de los difuntos, junto con ajuares que contienen joyas, los típicos jarros de boca de seta, cuencos y platos. De esta población han quedado importantes hallazgos en la Necrópolis de Jardin, situada a $300 \mathrm{~m}$ al norte de Toscanos, descubierta en la primavera de 1967; se estudiaron un total de 101 enterramientos de carácter individual, aunque pudo tener 200 enterramientos o más y constituye uno de los mayores cementerios fenicios occidentales conocidos. Para Schubart, la necrópolis ofrece distintos sectores diferenciados por su uso en el tiempo, pues sus inicios se producen en el siglo VI a.de C. vinculándose a los últimos momentos de Toscanos, pero los sectores más recientes, de los siglos V-IV a. C., fueron utilizados por los habitantes de la nueva ciudad púnica de Cerro del Mar.

Enfrente de Toscanos, se ubica el Cerro del Mar, cuyas excavaciones fueron dirigidas por Gamer y luego por 0. Arteaga siendo ambos miembros del equipo del Instituto Arqueológico Alemán. En él se localiza la ciudad púnico romana que Arteaga reivindica como Maenoba, si bien durante el siglo VII a. de C. el lugar fue utilizado

\section{El alto número de yacimientos \\ fenicios de La Axarquía \\ sitúa a este territorio entre \\ los más conocidos por las \\ investigaciones arqueológicas \\ internacionales}

como necrópolis de la ciudad de Toscanos. Para este investigador, los inicios deben acaecer hacia el siglo $\mathrm{VI}$ a. de C. con una ocupación ininterrumpida hasta el siglo II a. de C. La ciudad conocería desde época púnica una especial relación con la producción de salazones teniendo una destacada proyección industrial a partir de la época romana imperial.

Otra necrópolis se descubrió en la ladera oriental del Cerro de la Molineta (Lagos, Vélez-Málaga), a algo menos de $2 \mathrm{~km}$ del poblado de Chorreras. El hallazgo consistió en dos tumbas de incineración, en forma de pozo, que debieron formar parte de una necrópolis mayor, y que ha ofrecido una serie de materiales fenicios de la segunda mitad-finales del VIII a. de C. Entre ellos destaca un espléndido vaso egipcio de alabastro, semejante a otros hallados en los ambientes funerarios.

Tampoco podemos dejar de mencionar la necrópolis del Cerrillo de las Sombras en Frigiliana que pertenecería a un poblado todavía no descubierto. Es una necrópolis de los siglos VII-VI a. de C. Son tumbas de incineración consistentes en pequeños hoyos excavados en el terreno, dentro de las cuales aparecen, utilizando como urnas, vasos cerámicos pintados que contienen los restos cremados de los cadáveres y, como ajuar, una serie de objetos metálicos y fragmentos de armas de hierro, todo cubierto por un pequeño túmulo. Debido al tipo de enterramientos se considera que no es fenicia sino indigena y correspondiente a las poblaciones autóctonas que habitan la zona y mantenian relaciones comerciales con sus vecinos fenicios.

También junto a Toscanos hallamos el Cerro del Peñón, en él durante 1933 y 1942 Schulten realizó varios sondeos arqueológicos en su cima, donde descubrió restos arqueológicos que vinculó con la ciudad griega de Mainake. A partir de 1964, el Instituto Arqueológico Alemán de Madrid llevó a cabo varios sondeos en la cima que continuarian en años posteriores, siendo este cerro interpretado como una zona de expansión de Toscanos a mediados del VII a. de C.

Un yacimiento descubierto hace pocos años lo tenemos en Los Algarrobeños, a unos $3 \mathrm{~km}$ de Toscanos en un espolón norte-sur de la margen izquierda del río en lo que debió ser una pequeña colina inmediata a la antigua ensenada del Vélez. Aqui se han encontrado materiales que datan sus comienzos en el siglo VII a. de C. y con instalaciones industriales, probablemente alfareras. Este 

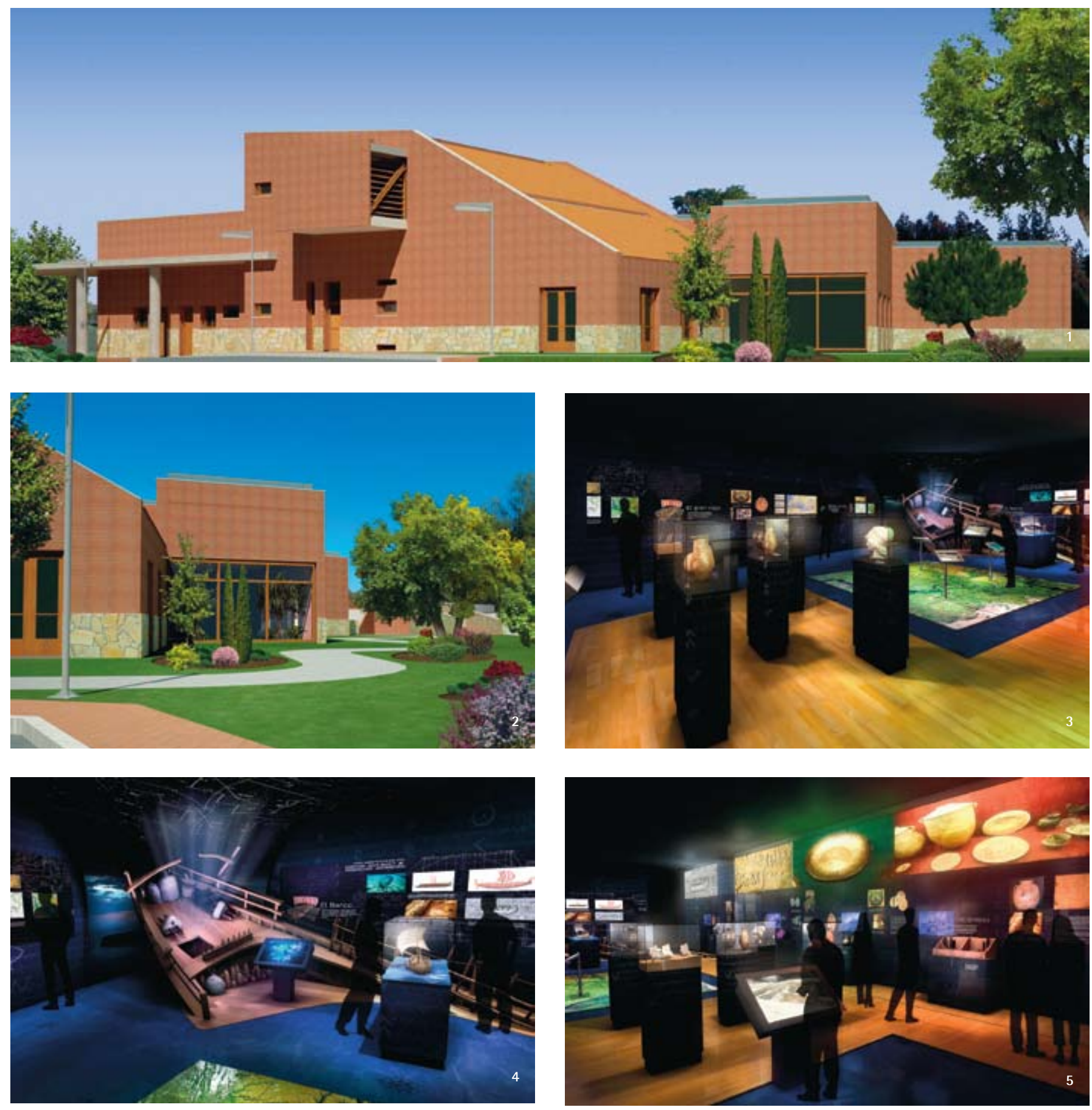

Imágenes en 3D sobre el proyecto del futuro centro de interpretación del yacimiento fenicio del cerro del Villar. Infografías: Antonio Vargas (1 y 2), Egmasa (3-5)

posible alfar, dependiente del centro nuclear de Toscanos, debió formar parte de esos pequeños asentamientos que se distribuyeron en el territorio económico de aquél. Otro importante centro industrial productor de cerámica fenicia en Algarrobo seria La Pancha, a $900 \mathrm{~m}$ de Morro de Mezquitilla y junto a la necrópolis de Trayamar en el que se elaboraban principalmente ánforas, pithoi y platos, entre la segunda mitad-final del VII a. de C. y primer cuarto del VI a. de C.

Cerca de Málaga, en la desembocadura del río Guadalhorce, se halla otra importante factoría fenicia de finales del VIII a. de C. También aqui el espacio ha cambiado ya que originariamente se ubicaria, a juzgar por los estudios paleotopográficos realizados, en un islote de forma oval, originado por los aportes del río sobre una barra fluvial y que tendria unas 9 o 10 hectáreas. Este Cerro del Villar, cuya altura máxima era de cinco metros sobre el nivel del mar, sufrió inundaciones marinas y fluviales, que provocarian su abandono hacia el 580 a. de C.; ya en los siglos $V$ y IV a. de C. se reocupó pero sólo como zona industrial de alfares, posiblemente dependiendo de Malaka. En relación con el último simposio internacional sobre Málaga en la Antigüedad (otoño 2006), su investigadora principal, la Dra. Aubet, ha publicado que el espacio de mercado descubierto en el Cerro del Villar es un sector mercantil de características similares al de Toscanos; se trataría de una calle central delimitada por viviendas grandes fechadas a finales del IX y principios deI VIII a. de C. y flanquea- 
El esfuerzo de las

administraciones locales

y autonómicas por difundir este

rico patrimonio se concreta a

través de la futura Ruta Fenicia

y centros de interpretación

como Playa Fenicia y Cerro

del Villar

da a un lado por pequeñas estructuras porticadas abiertas a la calle destinadas a tiendas, en las que aparecieron ánforas con restos de pescado y productos agrícolas; a la segunda mitad del VII a. de C. pertenecen una serie de edificios cuadrangulares y de viviendas de planta rectangular, con numerosos materiales arqueológicos, algunas cerámicas etruscas y otras samias, que prueban el amplio ámbito de relaciones mediterráneas que sostuvo el Cerro del Villar.

Durante algún tiempo se pensó que los habitantes del Cerro del Villar cuando abandonaron la isla hacia el 580 a. de C. fundaron Malaka, la actual Málaga, pero los materiales cerámicos del VIII a. de $\mathrm{C}$. encontrados en ella obligan a pensar en una fundación más temprana; otros hallazgos en las laderas de la Alcazaba, el Teatro Romano, calle Cister y San Agustín, nos muestran numerosos testimonios de la fundación colonial arcaica. Son los restos aparecidos e integrados en la parte inferior del Museo Picasso (Málaga) los que tienen mayor interés como lugar a percibir: son visitables los restos de la muralla de casamatas con torreones de planta cuadrangular datada a partir del VI a. de C. En un solar contiguo, se han localizado restos de un lugar de culto, un ara en forma de piel de toro.

\section{PERCEPCIONES DEL VISITANTE}

El patrimonio cultural y el natural se ven afectados, en gran medida, por dinámicas propias del medio físico, pero, sobre todo, de las actividades humanas. Su conservación y transmisión a las siguientes generaciones se pueden realizar manteniendo y mejorando la calidad de vida de la población que usa el espacio, ofreciendo propuestas concretas para su desarrollo sostenible y plural. En la costa oriental de Málaga, las actividades humanas de los colonos fenicios han dejado en el paisaje improntas reconocibles en la actualidad, que han conformado, a lo largo del tiempo, el espacio que hoy es percibido por parte de la población residente y visitante. Estas improntas, la mayoria, materializadas en sitios arqueológicos de excepcional singularidad, son hoy día Bienes de Interés Cultural. En este sentido, se protegen legalmente, y se busca la colaboración pública y privada para su conservación y difusión. Los proyectos en los que se están trabajando relacionados con la ruta fenicia de la provincia de Málaga se exponen a continuación:

\section{Playa Fenicia}

Proyecto de iniciativa municipal en colaboración con otras instituciones como la Consejería de Cultura y la Consejería de Turismo de la Junta de Andalucia. Pretende llegar a ser un complejo que albergará los restos fenicios de la desembocadura del río Vélez y Algarrobo.

El proyecto turístico, cultural y medioambiental se ubicará en la desembocadura del río Vélez, lugar en el que se concentran los restos de las ciudades fenicias de Maenoba (Cerro del Mar) y Toscanos, las necrópolis del Jardín y Casa de la Viña, la muralla de Alarcón y un barrio industrial en el Cerro del Peñón. La mayoría de estos yacimientos fueron estudiados y excavados por el Instituto Arqueológico Alemán entre los años 60 y 80 del pasado siglo.

El proyecto de Playa Fenicia contempla la puesta en valor de los yacimientos, la realización de senderos peatonales para permitir las visitas y la construcción de un Centro de Interpretación.

\section{Cerro del Villar. Desembocadura del río Guadalhorce}

El Centro de Interpretación del yacimiento fenicio del Cerro del Villar en la desembocadura del río Guadalhorce es un proyecto intimamente ligado al Paraje Natural donde se ha llevado a cabo un proyecto de restauración hidrológica y ambiental para prevenir las inundaciones y avenidas en la ciudad malagueña, que ha permitido incrementar la avifauna de este humedal en número de ejemplares y especies. Para disfrutar de este paraje la Consejería de Medio Ambiente ha rehabilitado el antiguo puente ferroviario, que permite el acceso a la desembocadura del rio, se han construido cinco observatorios, se han habilitado más de 2 kilómetros de senderos y se ha instalado una completa red de señalizaciones en la que se ofrece al visitante información sobre los valores de este paraje y de las zonas sensibles y restringidas para evitar perjuicios a la flora y la avifauna. Para completar estos equipamientos está previsto abrir al público en un futuro el nuevo centro de interpretación del Cerro del Villar, a través del cual se difundirá el rico patrimonio natural y cultural de este espacio natural con la explicación sobre la importancia fenicia en el territorio y su modificación con las actividades y relaciones con los indigenas en el mismo.

Las obras realizadas por las antiguas Confederación Hidrográfica del Sur y Cuenca Mediterránea se han ejecutado siguiendo los criterios y medidas promovidas desde la Consejería de Cultura y de Medio Ambiente, para que esta actuación fuese más allá de la corrección hidrológica y de la mera intervención preventiva en el cauce, para convertirse al mismo tiempo en un proyecto de conservación y restitución de los grandes valores ambientales y culturales de este territorio. 


\section{La fábrica de azúcar de Torre del Mar, elemento de un paisaje histórico}

\section{LAS VEGAS DE LA AXAROUÍA, UN ORIGINAL PAISAJE AGRO-INDUSTRIAL}

El origen del cultivo de la caña y fabricación del azúcar data en La Axarquía desde la época nazarí, contando con su presencia en nuestro entorno hasta el siglo XXI. La instalación fabril más antigua de la que tenemos noticias concretas, ya en época cristiana, es la del Ingenio Alto de Torrox, que era propiedad de moriscos y cristianos viejos antes de la rebelión morisca de 1569 .

Durante mucho tiempo llegó a establecerse un paisaje industrial y agrario en torno al sector azucarero, basado en el cultivo de la caña en las vegas costeras mediterráneas, y en la fabricación de azúcar y sus derivados en los trapiches, ingenios y fábricas de la zona.

En La Axarquia aún hay testimonios que nos dan idea de aquel paisaje azucarero. La caña ha dejado de cultivarse definitivamente después del cierre reciente de la fábrica de Salobreña (costa de Granada), quedando aún algunas manchas residuales de este cultivo en algunas vegas. En el aspecto industrial todavía podemos contemplar bastantes elementos de interés: el ingenio de Frigiliana, fundado en el siglo $X V I I$, es el único que aún sigue en funcionamiento como fábrica de miel de caña. Respecto a otros edificios y artefactos, se conservan de diversas épocas. Destacan las ruinas de dos ingenios preindustriales del siglo XVI, milagrosamente en pie todavía: el de San Antonio Abad en Nerja y el de Armengol en Maro. De la época industrial quedan las ruinas de los edificios de las azucareras San Joaquín de Maro, San Rafael en Torrox, Nuestra Señora del Carmen en Torre del Mar y San José en Nerja, entre otros. Relacionado con el de San Joaquin está el impresionante y bello acueducto del Águila catalogado como BIC por la Junta de Andalucia.

\section{EL INGENIO DE TORRE DEL MAR, PRIMERA FÁBRICA INDUSTRIAL DE LA COMARCA}

La industria azucarera en Torre del Mar se inició en 1796, año en el que José García Navarrete solicitó autorización para la construcción de un ingenio. En 1799 ya se encontraba terminado el edificio y en 1810 el viajero William Jacob nos habla de él: el molino para moler cañas consiste en tres cilindros de hierro perpendiculares, movidos por mulas, que exprimen el jugo que se conduce desde aqui por trojes de madera a las calderas.

Ramón de la Sagra, filósofo y empresario -emprendedor, diríamos hoy-, impulsó en 1845 la creación de la "Sociedad Azucarera Peninsular" con objeto de introducir la industrialización en el sector, y en 1846 levantó una fábrica azucarera moderna en el anterior ingenio de Torre del Mar. El proyecto fracasó al no poder instalar en ella el nuevo procedimiento de Derosne: utilización del vapor para la cocción de los jugos y empleo de centrifugadoras para la separación de la sacarosa cristalizada y la melaza. Poco después, en 1852, la fábrica pasó a manos de Larios Hermanos y Cía., convirtiéndose en un avanzado establecimiento fabril denominado Nuestra Señora del Carmen.

Los Larios estarían dirigiendo 134 años la fábrica de Torre del Mar, a la vez que detentaban un gran poderío económico y político en la comarca. Durante décadas los agricultores recibian los préstamos necesarios para emprender las cosechas, pero después dependian de que la Compañia Larios les comprase la producción. Hacia 1879 se habian convertido en los más importantes azucareros de España con 7 fábricas en la costa mediterránea andaluza (entre ellas Torrox, Nerja y Torre del Mar), con una capacidad de molienda de unos 6 millones de arrobas al año (el $40 \%$ del potencial de Andalucia en el sector).

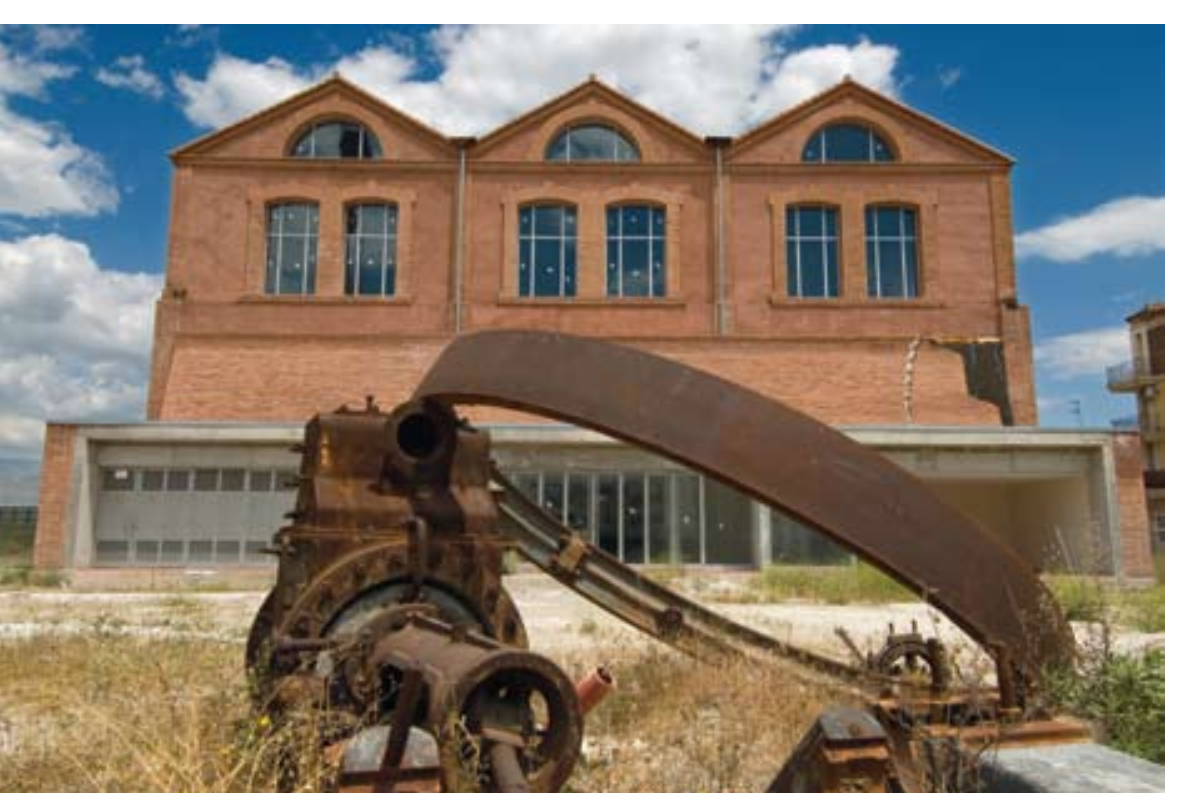

Fachada de la azucarera de Torre del Mar. Foto: Juan Carlos Cazalla, IAPH

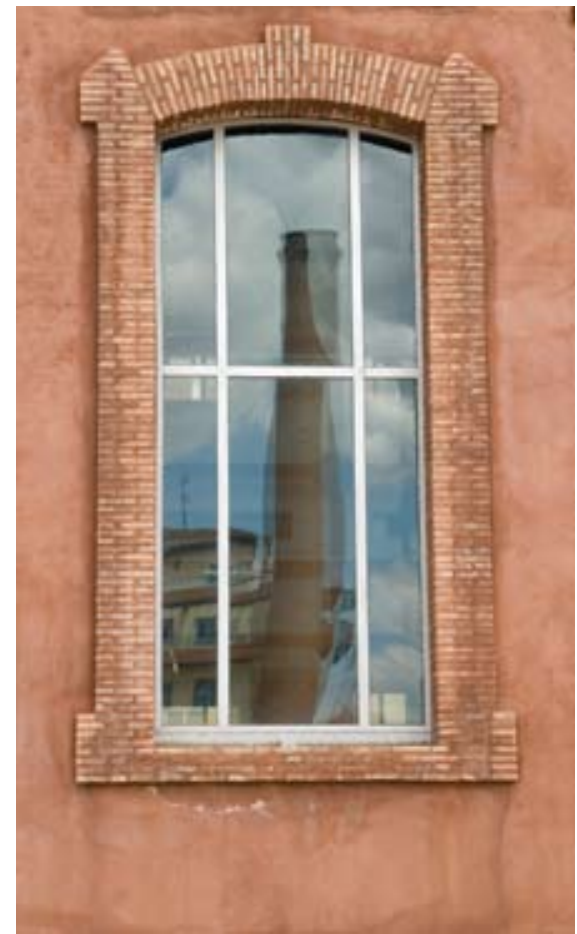

Ventanal de la azucarera de Torre del Mar. Foto: Juan Carlos Cazalla, IAPH

En 1903, se originó una crisis de sobreproducción motivada por la puesta en marcha de más de 20 nuevas fábricas de remolacha azucarera. Ante esta situación se constituyó la Sociedad General Azucarera de España, al objeto de reorganizar el sector. Durante el primer tercio del siglo XX se cerraron 36 instalaciones a instancias de la Sociedad General Azucarera, algunas de ellas con pocos años de antigüedad. Mientras tanto los Larios, que no participaron en la anterior Sociedad, continuaban en la comarca con su sistema de préstamos por adelantado a cuenta de las cosechas y se adueñaban de las fincas de pequeños propietarios y arrendatarios.

Al llegar la década de 1940 todavía quedaban funcionando en La Axarquía, sin contar algunos ingenios y trapiches menores, las fábricas de San Rafael en Torrox, San José en Nerja y Na. Sra. del Carmen en Torre del Mar. Después, en los años 70, se produce la liquidación de la caña como recurso productivo en la costa andaluza. En 1976 en Torre del Mar, única fábrica ya en funcionamiento de La Axarquia, ante la crisis empresarial, la Cooperativa Sindical Comarcal de Productores de Azúcar y Remolacha acordó la compra de la misma a la Sociedad Azucarera Larios.

En 1982, ante la prohibición de la importación de melazas, la compañia Ron Bacardí formó una sociedad con la Cooperativa Cañera para obtener ron de calidad: así surgió la Sociedad Azucarera del Mediterráneo S. A. (SAMESA). En 1986 Bacardí vendió sus acciones a la Azucarera del Guadalfeo, que pasó a controlar la fábrica como socio mayoritario. Desde 1988 la producción de caña empezó a disminuir de 


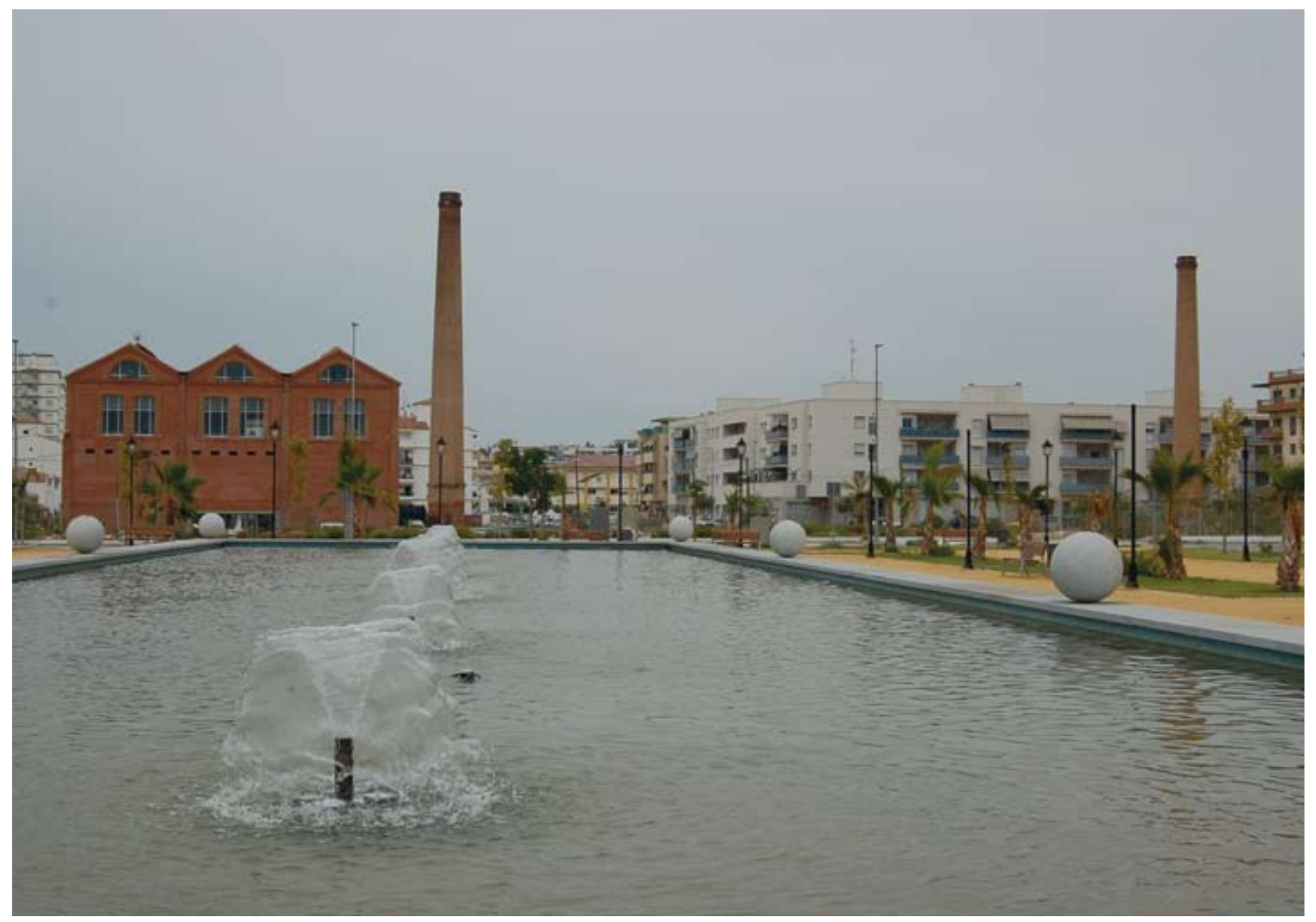

La azucarera de Torre del Mar está integrada en el casco urbano del municipio. Foto: Juan Carlos Cazalla, IAPH

forma drástica y en 1991 se dio la última campaña en Torre del Mar.

\section{EL EDIFICIO COMO ELEMENTO CULTURAL DE UN NUEVO PAISAJE URBANO}

En 1993, después que los chatarreros habian sacado las piezas más valiosas, se firmó un convenio entre el Ayuntamiento de Vélez-Málaga y la Sociedad Azucarera del Mediterráneo S. A. (SAMESA) por el que se acordaba la rehabilitación del edificio central de la fábrica, contemplando la demolición de los cuerpos añadidos, a fin de su conversión en Museo del Azúcar. El convenio quedó en letra muerta durante mucho tiempo respecto a los planes con el edificio de la fábrica. Sin embargo la denominada Casa del Ingeniero, edificada en 1888, fue rehabilitada para acoger la tenencia de alcaldia de Torre del Mar. En 1999 se restauró por la Consejería de Turismo una máquina de vapor fabricada en 1900 por la compañia Fives-Lille, y se emplazó como monumento delante de la citada Casa del Ingeniero.

En 2003 a través de la Consejería de Turismo se acometió de nuevo un plan de rehabilitación del edificio central de la fábrica al objeto de convertirlo en Centro de Difusión Turística. El proyecto, firmado por Francisco González, contempla los siguientes usos: en la planta inferior, museo del azúcar y salón de actos; en la planta primera, biblioteca, aulas y despachos; en la segunda y tercera, oficina de turismo y espacio expositivo. A la vez se prevé la integración de las tres

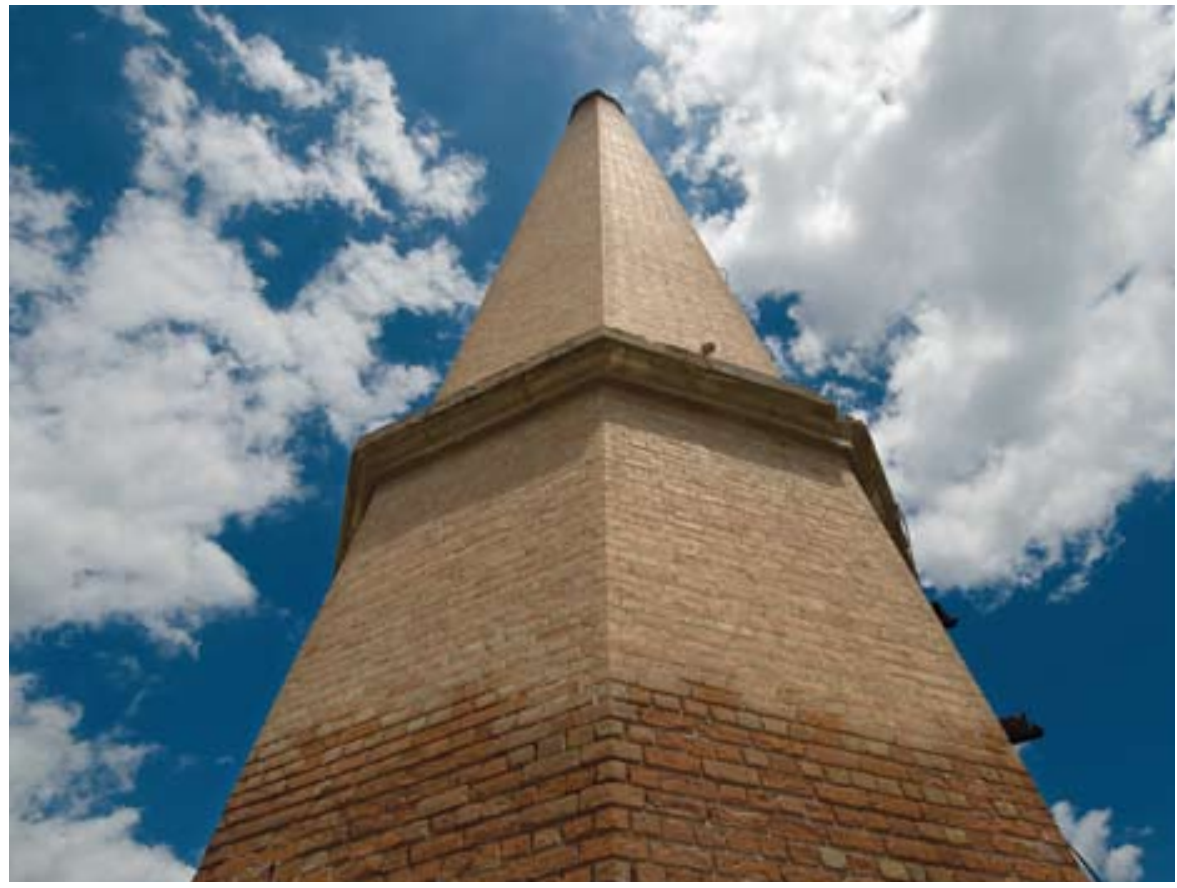

Perspectiva vertical de la antigua chimenea de la azucarera. Foto: Juan Carlos Cazalla, IAPH

chimeneas en el área urbana de la zona. El edificio industrial conservado pertenece a una ampliación realizada por Larios en torno a 1900.

Después de muchos años de abandono, la maquinaria que quedaba en estos momentos era escasísima, y se propuso la conservación de algunos compresores de carbono, malaxadores, tachas y piezas complementa- rias, que permanecian abandonadas entre las ruinas, para integrarlas como elementos decorativos. En la actualidad se siguen realizando las obras de rehabilitación del edificio.

Antonio Guzmán y Antonio Santiago

Investigadores del patrimonio industrial de Málaga 


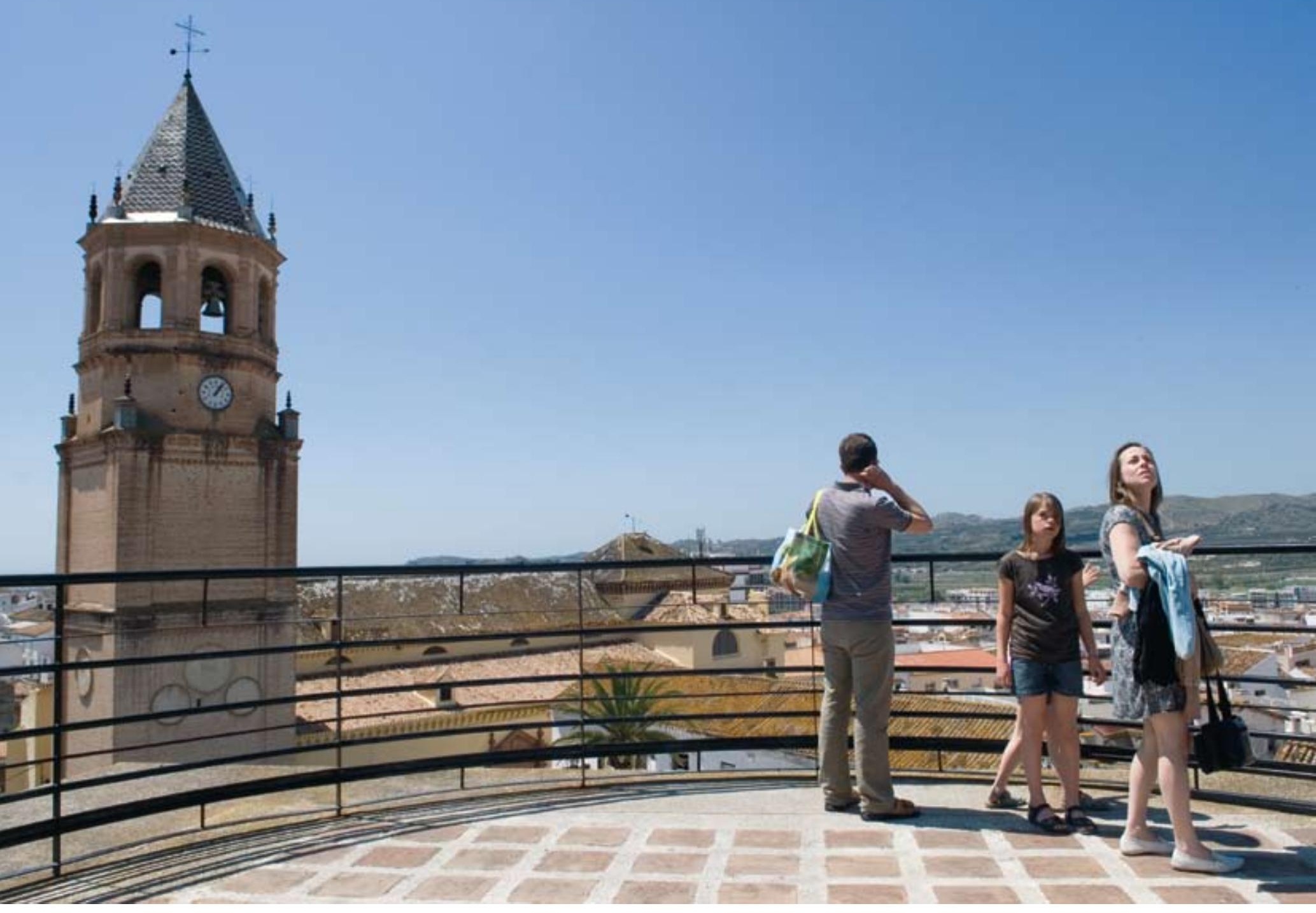

Entorno turístico de la iglesia de San Juan Bautista en Vélez-Málaga. Foto: Juan Carlos Cazalla, IAPH 


\section{Turismo y cultura}

Alfredo Rubio Díaz, Dpto. de Geografía, U. de Málaga
En la actualidad cualquier intento de comprensión de algo alcanza una cierta categoría de desmesura, ya sea por la sobreabundancia de información caracteristica de la sobremodernidad ya por la problemática implícita en las palabras. Determinar la calidad de la información y superar el vacío de las palabras se convierten casi en las labores previas, en la totalidad del ejercicio. Esa es la perspectiva de este breve artículo: el problema de abordar las relaciones entre cultura y turismo siendo ambas palabras problemáticas, siempre y cuando no nos arriesguemos a asumir su empleo vacío. Sin duda, una tercera dificultad procede de establecer la adecuada relación entre ambas y un territorio concreto: La Axarquía malagueña, las tierras del este geográfico de la provincia de Málaga.

En los países ribereños del Mediterráneo las actividades turísticas han desempeñado un importante papel en su crecimiento económico. Lentamente, tras transformar las costas, el fenómeno se ha ido expandiendo por las tierras interiores a la vez que la demanda turistica también experimentaba profundos procesos de cambio por segmentación. A partir de la década de los años noventa el "mare nostrum" se convirtió en el primer destino turístico internacional. El proceso ha sido complejo: primero estuvo reservado a una elite que actuó como prescriptora de los movimientos de masas que, tras la reconstrucción europea, iniciaron su despegue como consumidores turisticos.

El conocimiento de lo que podriamos Ilamar la fenomenología profunda del turismo de masas es esencial, es decir, cómo se ha construido un imaginario colectivo, cuyos antecedentes son diversos -desde los viajeros del siglo XVIII a los balnearios y "la invención de la playa"; desde el higienismo y la puesta a punto de los cuerpos para la producción del siglo XIX a los programas de vacaciones obreras de los fascismos europeos. Un imaginario que, en todas partes donde es posible, es construido con la ayuda de los creadores de sentido, ofreciendo un tiempo de estado de excepción en un lugar otro, que permite literalmente escapar de las condiciones de una vida insatisfactoria en los territorios de lo urbano.

En ese contexto, la mayoria de los espacios turisticos de masas del litoral de la provincia de Málaga, afectados por la produc- ción turística del territorio, han agotado su ciclo como productos turísticos e incluso sus suelos, dejando una herencia de difícil resolución. En algunos casos, hoy son territorios urbanos de la máxima complejidad. Crece en ellos el sector residencial inmobiliario sobre las cenizas de los antiguos territorios preturísticos y en la realidad de los paisajes banalizados del turismo de masas se expande la realidad de una región metropolitana (RUBIO SERRANO, 2007).

Si se entiende el turismo como una relación, aquella que ocure entre receptor y visitante, como cualquier otra requiere de una sede donde hacerla efectiva. Dicho de otro modo, será el territorio el suelo donde se haga acto. Viene todo esto al caso de La Anarquía puesto que, de algún modo, aquí la relación ha podido ser reflexionada como acondicionamiento previo de una sede a una demanda aún incipiente, al menos por comparación respecto de territorios sobre-desarrollados como la Costa del Sol Occidental. Podemos abordar esa reflexibilidad previa y preparatoria a través de un documento significativo: el Plan de Ordenación del Territorio de la Costa del Sol Occidental-Axarquía de Málaga (2006).

En su Memoria Informativa los procesos territoriales en curso se definen y diagnostican como reescritura actual de un paisaje heredado -denominado tradicional- apoyado por los procesos de crecimiento residencial tanto en el medio litoral como en el rural. Por tanto, el ámbito se encuentra en un extraordinario proceso de transformación con un buen potencial de crecimiento que requiere corregir sus principales disfuncionalidades (POT Litoral Oriental-Axarquía de Málaga, 2006: 13). Estas alcanzan un momento crítico debido a la colmatación y compactación de la franja litoral acompañado de un proceso de dispersión residencial extensiva en el interior, no reglado y en muchas ocasiones producto de parcelaciones ilegales.

Se entiende entonces que, de continuar así, podría agotar en las proximidades del litoral las posibilidades de un posible desarrollo turístico basado en el alojamiento hotelero, el cual es capaz de generar empleo y actividad de forma más intensa y durante un periodo estacional más largo (POT, 2006: 18). Este 


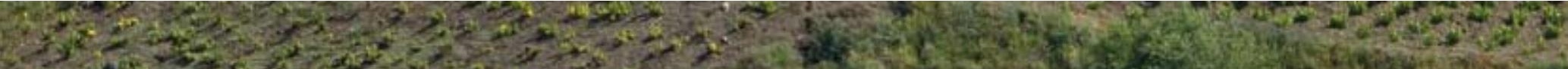

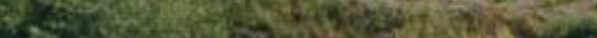

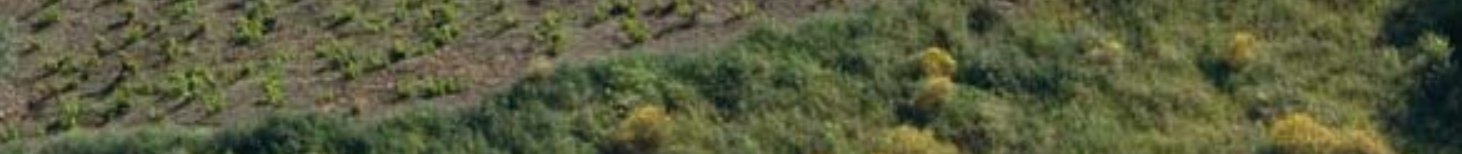

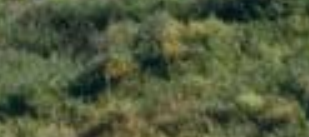

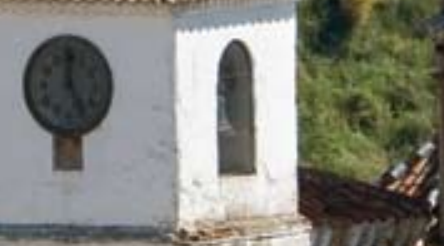

metas
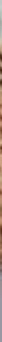


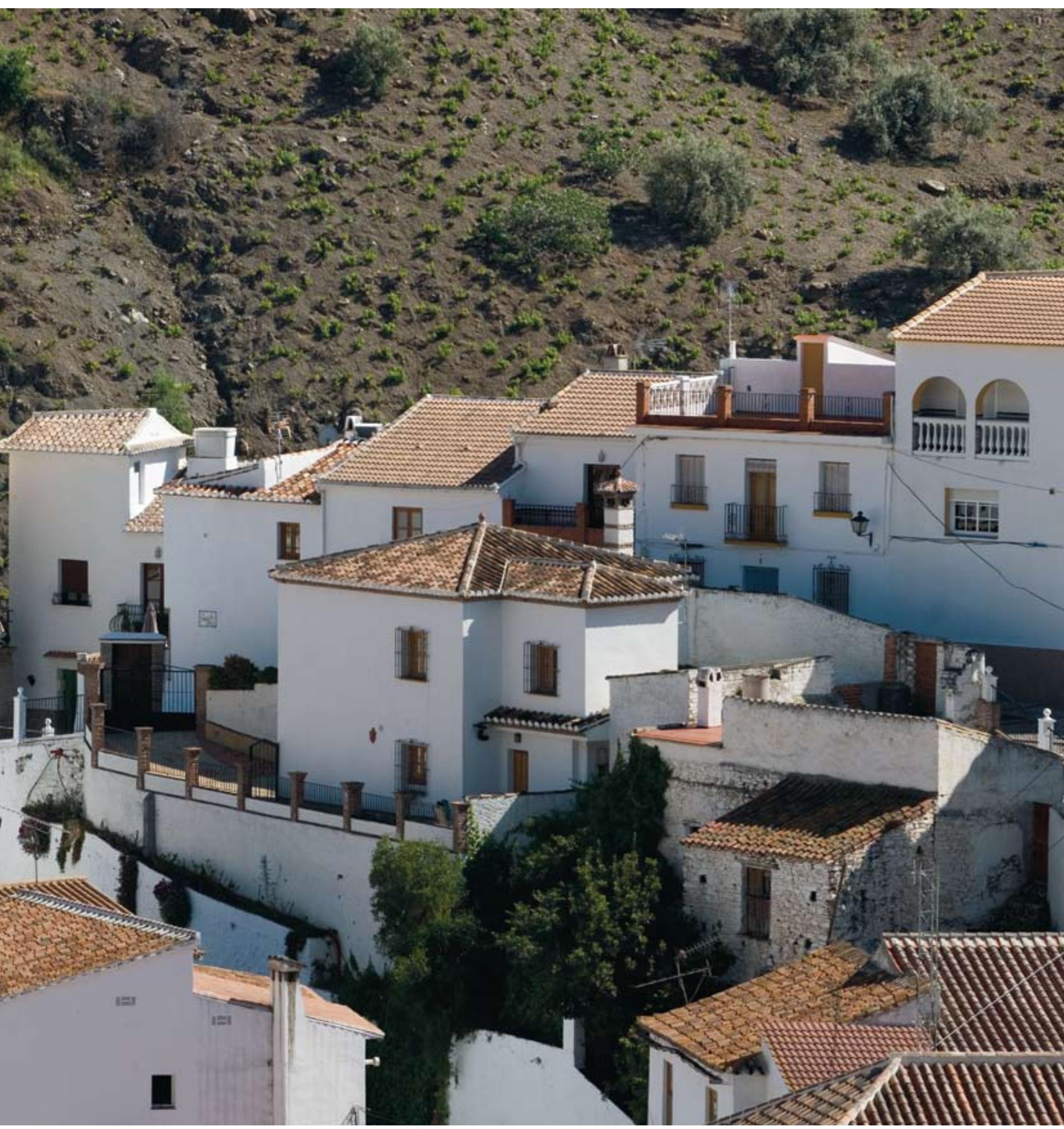


diagnóstico se completa con tres claves medioambientales: el deterioro del paisaje, el incremento de riesgos naturales y los límites del recurso agua en una cuenca deficitaria. En cierto modo, como hemos explicado en otro lugar, los costes derivados de la permanencia del "modelo" actual consisten finalmente en el deterioro de (...) los hitos paisajisticos y de formas y elementos constructivos que han dado lugar a la singularidad de su paisaje e identidad al territorio axárquico (POT, 2006: 66). Esta reducción de lo cultural a las señas de identidad paisajística (incluida la arquitectura) es lo que sirve a los redactores para justificar posteriormente las medidas de protección que se arbitran en las normas para proteger lo que denominan capital territorial (POT, 2006: 66-67).

Por tanto, la orientación del territorio serán las actividades turisticas, aunque descartando la urbanización masiva (con la excepción del litoral, como veremos), e inclinando la oferta hacia lo que denomina turismo productivo (fundamentalmente el hotelero, pero también todas aquellas actividades empresariales relacionadas con el ocio, comerciales, deportivas y recreativas, etc.), creando condiciones para que la ordenación urbanistica configure espacios bien ordenados y de calidad urbana y ambiental (POT, 2005: 80). Por otra parte, las referencias en el "Diagnóstico" a las economias productivas son muy reducidas, cuando no inexistentes $y_{1}$ por lo que se refiere a las logísticas e industriales se supone que crecerán vinculadas a la expansión de la aglomeración urbana de Málaga (POT, 2006: 33).

Esta orientación suscita una primera cuestión: la mirada planificadora no ha encontrado nada más que el paisaje en la potencia del territorio. Parece tanto una mirada cansada, que no es capaz de dar cuenta de la potencia, que se adscribe a las manifestaciones formales (de una sociedad y su cultura), como interferida por un a priori que hace imposible ver otra cosa. Según el Plan, en La Axarquía no parece existir otro impulso posible. Visto así, lo eficaz será transferir a la "valiosa identidad comarcal" el valor de dimensión competitiva (POT, 2005: 63) dado que, los productos turísticos basados en la "experiencia" -se enfatiza- y en los ingredientes singulares del destino tienen una aceptación creciente, y La Axarquia dispone ahi de un caudal potencial decisivo siempre y cuando, se reitera, se modulen las tendencias propias del mercado, aprovechando la energía que proporciona la demanda con el fin de lograr los objetivos fijados en este Plan de Ordenación del Territorio. El modelo que se propugna pretende que, junto a un aprovechamiento ordenado de la oportunidad de crecimiento, se conserve y se incremente el capital del territorio, tanto el de carácter natural, como el cultural e identitario (POT, 2006: 64).

Se hace un recuento exhaustivo de los diversos elementos que deben ordenarse de acuerdo con esa intención, que en conjunto integran lo que se define como espacio turístico comarcal (POT, 2006: 80). Todo esto supone la mayor parte de la extensión territorial de la comarca, pues sólo quedan al margen lo ocupado por la actividad industrial y logistica, las infraestructuras, las áreas de regadio y los asentamientos de primera residencia no afectados por protecciones de carácter histórico, cultural o paisajístico, es decir una superficie que no llega al 10\% del total. De todos los usos contemplados sólo se promueve el crecimiento de los turísticos; en concreto (...) la expansión de los alojamientos turisticos y la oferta de servicios empresariales (artículo 39.2 a), así como el (...) crecimiento ordenado de el sector turistico en el frente del litoral (artículo 39.2 c) y establecer las condiciones para el desarrollo del sector turistico en el interior de La Axarquía (artículo 39.2 d).

Además el Plan prevé las Zonas de Oportunidad para Actividades Comerciales y de Ocio (POT, 2005: 116), y con una intencionalidad más clara las Zonas de Dinamización Turistica destinadas al asiento de actividades del turismo "productivo" capaces de funcionar durante toda la anualidad. Estas proceden, en su mayor parte, de reservas territoriales que se realizaron a mediados de los años ochenta por protección paisajista del espacio productivo agrario y que en el momento presente han perdido su sentido y su justificación, por una parte, una vez desaparecido el cultivo de la caña de azúcar, que les dotaba de una identidad singular y, por otra, debido a las transformaciones acaecidas que, o bien ha dado lugar al abandono de las actividades agrícolas (regadíos tradicionales), su sustitución en ciertos casos (invernaderos) o permanecen improductivos, en todo caso, conformando espacios sin valores paisajísticos de interés.

De hecho estamos ante una operación de "clasificación urbanistica" (afín a la de "suelo urbanizable") directa por parte del Plan, la cual, por cierto, contribuye a una mayor colmatación urbana de la franja litoral. Pero las consecuencias no se limitan a esto: el hecho de que el POT juzgue estos terrenos como de escaso valor paisajístico no quiere decir que no puedan adquirirlo mediante su oportuna conversión en espacios libres, por ejemplo, y un tratamiento adecuado. Sin embargo esa posibilidad aparentemente ha cedido ante los intereses del mayor propietario de suelo en el litoral de la comarca, justificando la decisión adoptada por la necesidad de prever espacios concretos para cubrir ese déficit de oferta turística empresarial tantas veces esgrimido.

Con la perspectiva de los intereses generales esta elección es discutible, especialmente por lo que respecta a dos de estas zonas de dinamización turistica, las que ocupan los espacios litorales mayores que todavía permanecen relativamente libres: en la playa del Hornillo, al oeste de Torre del Mar, y el Playazo, a poniente del núcleo de Nerja. Estas dos operaciones reducirán los frentes de playa libres de la comarca, es decir, no ocupados por suelos urbanos o urbanizables al 5\% del total, con el argumento de su no identidad (RUBIO; SERRANO, 2007).

Suponiendo que lo anterior es una breve descripción transparente de lo que el POT supone podemos entrar ya más directamente en las cuestiones que nos ocupan. 

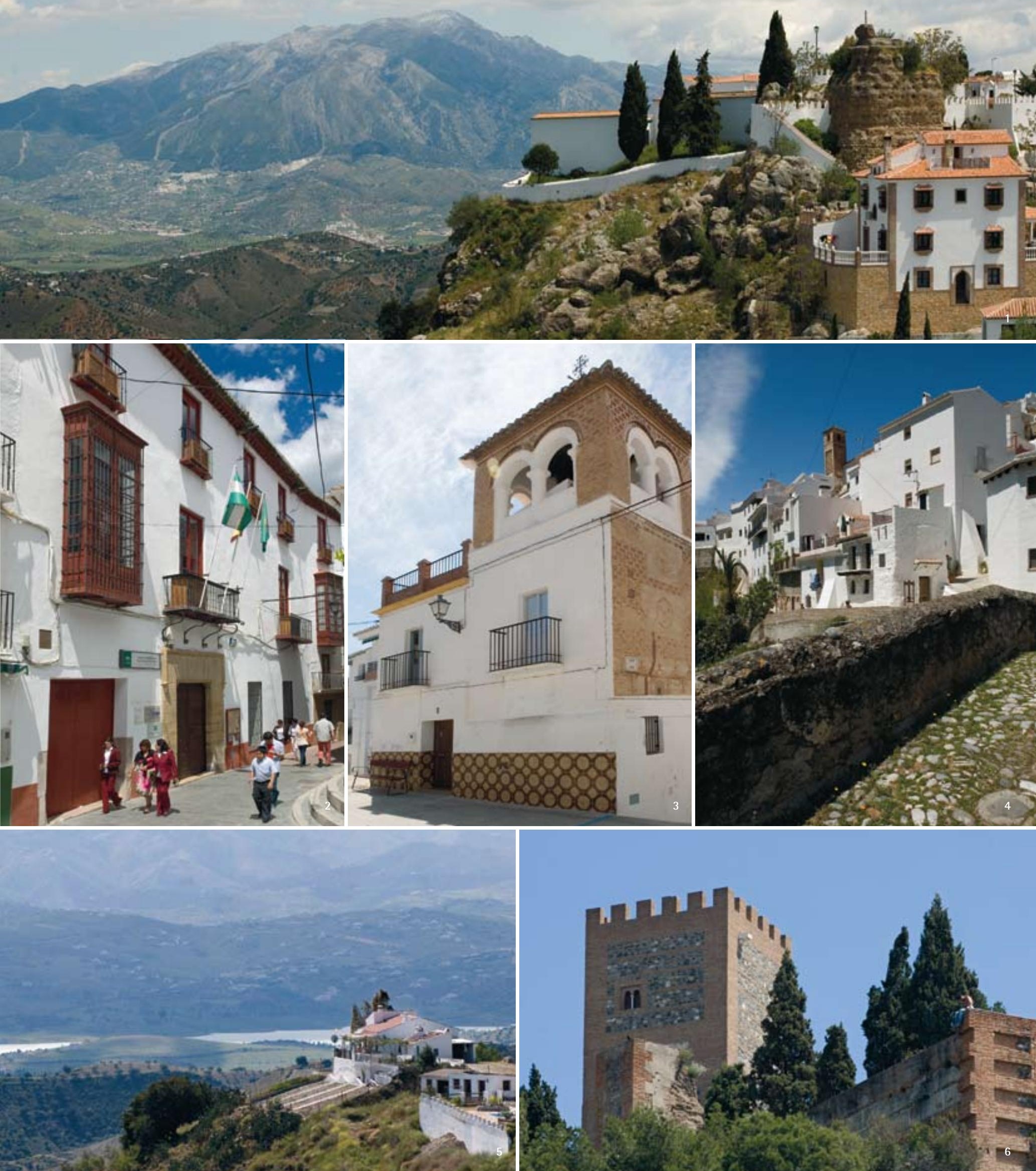

1. El castillo de Comares domina un paisaje de barrancos y montañas

2. Casa Cervantes en Vélez-Málaga

3. Arquitectura tradicional en Sedella

Fotos: Juan Carlos Cazalla, IAPH

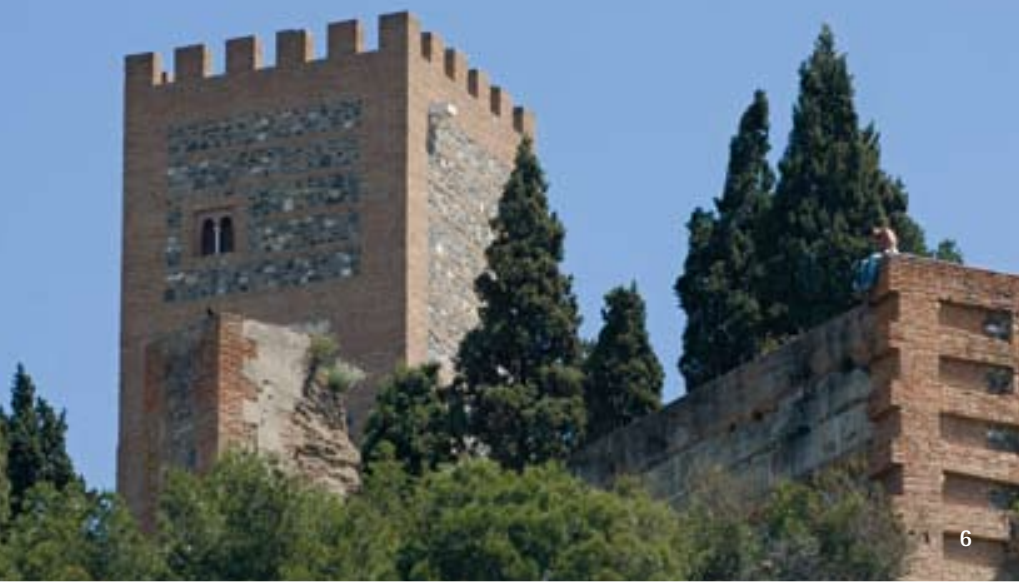

4. Vista de Salares desde el puente árabe

5. Paisaje desde Canillas de Aceituno

6. Castillo de Vélez-Málaga

Fotos: Juan Carlos Cazalla, IAPH 
El paisaje interior actual de La

Axarquía no es exactamente

un paisaje rural vivo, con una

población actuante como tal, puesto que la mayoría trabaja fuera

de La Axarquía interior

El territorio no puede ser explicado sin considerarlo también como proceso (y de ahi lo decisivo de comprender que la población es parte integrante del mismo), ni la cultura puede ser reducida a sus manifestaciones materiales, tampoco la belleza y la singularidad de un paisaje pueden ser mantenidas con simples disposiciones de un control puramente defensivo. El paisaje está vivo y tratar de congelarlo es prácticamente la misma operación que la tematización de ciertos espacios de la ciudad histórica. Pero, en este caso, al hacerse abstracción de los procesos culturales y sociales, ya no solamente acumulativos (y previsibles) sino también de los no previsibles (el cambio), lo único que se conseguirá es mantener el espejismo de un determinismo impuesto desde fuera y desde arriba.

El problema de fondo que aqui aparece es precisamente el de objetivar la transformación global de un territorio en un producto turístico "productivo" y que se habilita como "alternativo" cuando, y los estudios e investigaciones son muy abundantes, el turismo como actividad tiene la capacidad de readaptar la naturaleza y la cultura a sus propias necesidades (MACCANNELL, 2007: 11) y, lo que es peor, tiende a eliminar precisamente aqueIlo que lo desencadenó (HARVEY; SMITH, 2005: 32-33). Probablemente la mirada planificadora se ha enfrentado a las consecuencias acumuladas de los cercanos procesos (la Costa del Sol Occidental) buscando una salida alternativa. Sin embargo, no ha estudiado sus patrones: por ejemplo, los procesos posteriores a una fase inicial basada en la oferta hotelera de calidad, como sucedió en los casos de los municipios de Torremolinos, Benalmádena Costa y Marbella, se fundamentaron en un elemento de causalidad circular y acumulativa dando lugar a las actuales condiciones de hacinamiento constructivo. También parece ignorar que la construcción de un producto turístico, basado en la personalización del territorio como poseedor de una identidad, significa necesariamente su inserción en el ciclo de producto. En resumen, el territorio no se entiende en su singularidad irreducible, en su potencia propia de ser alguna otra cosa que sea distinta de lo heredado o de su degradación actual.

En este sentido, cabe preguntarse qué significa el concepto de "paisaje tradicional" en La Axarquía, cuando se pueden construir sin grandes dificultades cinco secuencias fundamentales en su proceso hasta llegar a la situación actual. El paisaje interior actual de La Axarquía no es exactamente un paisaje rural vivo, con una población rural actuante como tal, puesto que la mayoria trabaja fuera de La Axarquía interior. Donde, además, se insertan tanto el fenómeno de las urbanizaciones ilegales (unas veinte mil casas) que lentamente van transformando el paisaje que se desea conservar, pues (...) es precisamente la belleza de este paisaje el factor principal de su deterioro (POT, 2006: 12), como los distintos efectos de su pertenencia al área metropolitana de Málaga (suburbanización).

La preservación de las construcciones y demás elementos ligados al cultivo de secano tradicional, la función del cultivo del olivar como puro elemento (ornamento) constitutivo del paisaje para una economía, otra que la propia de lo rural, el férreo mantenimiento de la escala y extensión de los núcleos de población y toda una larga serie de medidas preservadoras significan la congelación del paisaje y con ello de la vida social y de la cultura implícita en la misma. Se propone una gigantesca escenografía donde una población está obligada a cumplir con una identidad construida desde un exterior para conseguir mantener inalterable un supuesto paisaje tradicional (una herencia dudosa como tarea). En realidad, lo que se perfila es un territorio donde el litoral actuará como receptor de un segmento turístico consumidor del binomio paisaje-cultura, alojado en hoteles acaso con encanto, y un interior cristalizado donde dichos turistas podrán vivir una experiencia a través de circuitos, rutas, sendas y "miradores".

El POT pretende evitar los más perniciosos efectos de una ocupación ahora descontrolada del medio rural; pero se trata de prohibiciones o limitaciones que no están acompañadas de otro tipo de soluciones, más profundas y capaces de articular otras opciones productivas, con el turismo como una actividad ponderada. Aplica medidas "formales" en los dos sentidos de la palabra: que atañen a la apariencia de lo que se construye y de la consecuente afectación del entorno territorial; y por otro lado formal, en el sentido de reglado, de lo que por su naturaleza jurídica sólo incide sobre los efectos de conductas sobre cuyas causas o motivaciones bien poco se informa.

Una complejidad fantástica caracteriza este territorio, lo que explica su singularidad. Preferimos esta palabra a la de identidad dado que esta remite a una condición de clausura y acabamiento, mientras que lo singular, en nuestra acepción, está siempre abierto y es creativo. Se debe recordar que, no siendo sujeto, el paisaje no puede encarnar exactamente una identidad. Con todo, el paisaje como exterioridad producida por una cultura, cristalizado como se pretende, y obligado indirectamente a repetirse a si mismo, pues sólo es producto y percepción de lo humano, excluye lo común. Dicha exclusión significa imposibilidad de uso tanto para habitantes como para turistas. 


\section{La Fundación María Zambrano}

\section{Desde su creación la fundación celebra diversas actividades culturales para difundir el pensamiento y la obra de María Zambrano}

La Fundación María Zambrano fue creada el 12 de junio de 1987 e inscrita en el Registro de Fundaciones Culturales Privadas de Carácter Cultural y Artístico por orden del Consejero de Cultura de la Junta de Andalucia del 23 de mayo de 1988.

Ello fue la culminación de un largo proceso que comenzaba en el año 1974 en que yo me hice cargo del Departamento de Filosofía de la recién creada Universidad de Málaga y me propuse dar a conocer los filósofos malagueños de relevancia en la Historia. El 9 de noviembre de 1977 dictaba yo una conferencia sobre el pensamiento de Maria Zambrano en el Ateneo de Málaga que despertó un gran interés. Dirigi una tesis de licenciatura sobre ella que fue defendida el 11 de diciembre de 1978. De acuerdo con el director del Departamento de Literatura, Cristóbal Cuevas García, propusimos a la Junta de Gobierno de la Universidad la concesión del Doctorado Honoris Causa conjuntamente a Jorge Guillén y Maria Zambrano. La intervención desafortunada de un profesor que gozaba entonces de poder en la Universidad hizo ver al Rector que María Zambrano no tenía méritos suficientes para tal distinción, lo que motivó que éste decidiera excluirla. El argumento que esgrimia tal profesor es que no aparecía en ninguna Historia de la Filosofía, lo cual era cierto e indicaba el desconocimiento que existía en nuestro pais, por aquel entonces, de la filósofa veleña. Se dio la coincidencia de que el mismo dia que se otorgaba el doctorado a Jorge Guillén se anunciaba la concesión del Premio Príncipe de Asturias a Maria Zambrano (3 de julio de 1981). Tras reiterados esfuerzos posteriores el título le fue concedido el 25 de abril de 1985

No comprendia yo cómo mis colegas estaban tan ciegos para no ver la grandeza y la originalidad genial de pensamiento de Maria Zambrano. Escribi en la prensa local un artículo titulado Indignación y esperanza (Sur, 3 de junio de 1981) y me decidi a buscar apoyos en ámbitos no académicos. Entre éstos estaba el Ayuntamiento de su ciudad natal, VélezMálaga. Hablé con el primer alcalde de la democracia en aquella ciudad, Juan Gámez Ruiz, y le hice ver la grandeza de aquella paisana suya que por aquel entonces se encontraba en el más absoluto olvido y la más lamentable miseria. El filósofo Ciorán habia preguntado por aquellas fechas a Fernando Savater: "Pero ¿se acuerdan en España de María Zambrano, el más original y creador de los discípulos de Ortega?" (El País, 21 de enero de 1981). Y Savater comenta- ba: "Este país tan misero filosóficamente hablando no puede permitirse el lujo de olvidar a uno de sus pensadores de mayor talento". Desde su exilio Maria Zambrano escribe desilusionada: "el exiliado ha dejado de existir ya, vuelva o no vuelva. Si le conceden un instante de atención ha de ser para extrañarse que siga habiendo exiliados" (Carta sobre el exilio, 1961). Una comisión del Ayuntamiento, presidida por su alcalde, fue a visitarla a Ginebra y nos propusimos recuperarla para nuestro país.

En la sesión de la Corporación Municipal del 30 de junio de 1981 se acordó por unanimidad "arbitrar los medios que fuesen necesarios para conseguir que María Zambrano vuelva a España", para lo que se propone concederle "unos recursos económicos

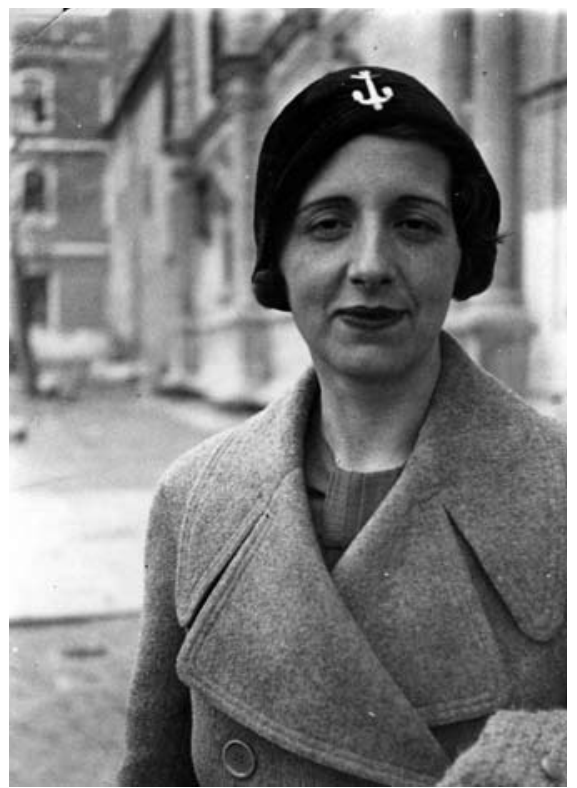

María Zambrano en Madrid durante la II República Fuente: Archivo Fundación María Zambrano

que (le) permitieran (...) pasar los últimos años de su vida en la ciudad que le vio nacer". Como jurídicamente no era posible concederle directamente esta subvención se decidió crear la Fundación que lleva su nombre y de la que fue su primera Presidenta. La Fundación se creó por un acuerdo entre la Consejería de Cultura de la Junta de Andalucia, la Diputación Provincial y el Ayuntamiento de VélezMálaga. Posteriormente se incorporó Unicaja y Salsa Inmobiliaria. Como contrapartida María Zambrano cedia a la Fundación la propiedad de su patrimonio cultural y el cuidado y difusión de su obra.

Desde su creación, y en cumplimiento de sus objetivos estatutarios, la Fundación ha venido realizando diversas actividades culturales tales como seminarios, exposiciones, premios de ensayo, becas, ciclos de conferencias y congresos. La Fundación ha celebrado cinco congresos internacionales sobre la vida y obra de María Zambrano. El primero, aun en vida de la fi-

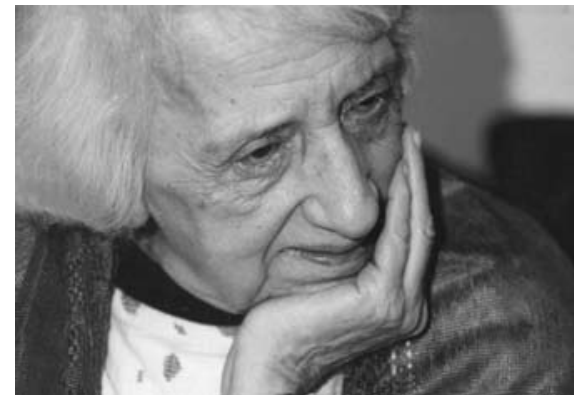

La pensadora de Vélez-Málaga a su regreso del exilio. Fuente: Archivo Fundación María Zambrano

lósofa, del 23 al 26 de abril de 1980. Le siguieron el segundo, que se celebró del 1 al 4 de noviembre de 1984, y el tercero que tuvo lugar del 2 al 5 de diciembre de 1998. El cuarto congreso, en el año 2004, centenario de su nacimiento, tuvo dos partes, en VélezMálaga y en Madrid, lugar en que lo presidió S. A. R. la Infanta Dña. Elena. En ese año tenemos constancia de que tuvieron lugar más de 40 congresos sobre el pensamiento de Zambrano en el mundo occidental desde Rumanía a EE. UU., pasando por México, Italia, Francia, etc. El último congreso internacional organizado por la Fundación ha tenido lugar del 22 al 25 de abril de 2008, como de costumbre en el Palacio de Beniel de Vélez-Málaga, sede de la Fundación.

Además, hemos celebrado Encuentros Internacionales en La Habana, del 11 al 15 de noviembre de 1994, en Morelia (México), del 24 al 27 de febrero de 1996 en Roma del 20 al 22 de septiembre del 2000, en Santiago de Chile, del 14 al 16 de octubre de 2002, y en San Juan de Puerto Rico en 2007.

A finales de 1991, tras el fallecimiento de Maria Zambrano, ocurrido el 6 de febrero de ese mismo año, y por voluntad testamentaria de la misma, todo su legado documental y bibliográfico pasa a conformar el Archivo y la Biblioteca de la Fundación. Estos fondos desde la primavera de 1992 están abiertos a la consulta de los investigadores y estudiosos de la obra zambraniana que han consultado sus archivos en estos años en número superior a 20000.

Desde 2008 la Fundación tiene abierto además un Centro de Estudios sobre el Exilio, que preside José Luis Abellán, dedicado al estudio de todos los exiliados españoles. También publica la revista Antigona, de la que ya han aparecido cuatro números.

Sin esta Fundación sería otra, sin duda, la imagen y la difusión que hoy tendriamos de María Zambrano. Como ella misma reconocía, la ayuda económica y la protección que le brindó la Fundación los últimos años de su vida le permitió alargar y difundir su pensamiento $y$, tras su muerte, proteger y dar a conocer su legado.

\section{Juan Fernando Ortega Muñoz}

Director de la Fundación Maria Zambrano 


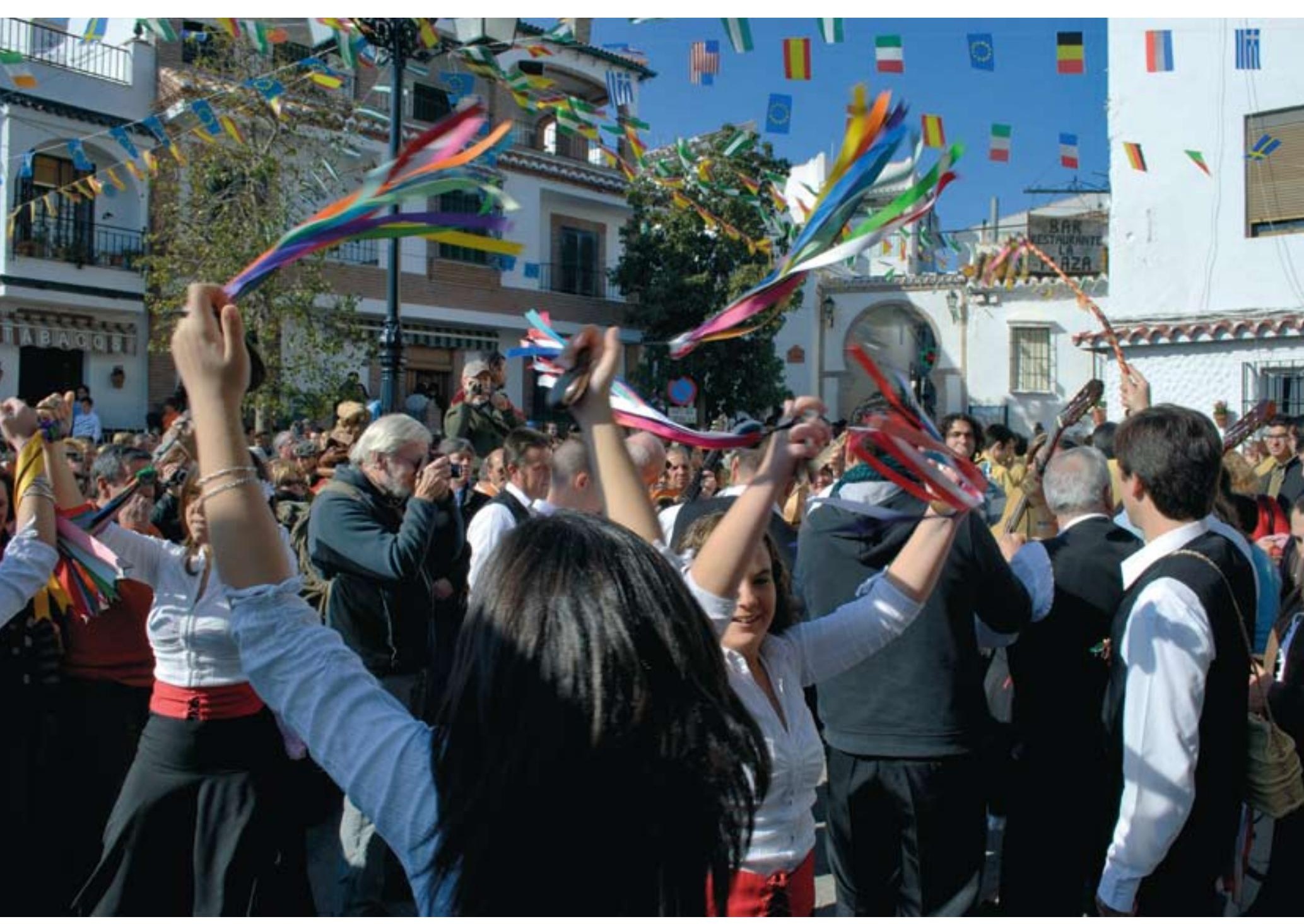

Baile en parejas en la plaza del Balcón de La Axarquía en Comares durante la celebración de San Hilario, con la panda y el alcalde dirigiendo. Panda Arroyo

Conca. Foto: Marc Ballester Torrents, IAPH 


\section{Fiesteros, fandangos, verdiales. Oralidad en transición en La Axarquía}

Marc Ballester Torrents, antropólogo

En un pasado cercano, en La Axarquia, creadores de coplas y contadores de historias al ritmo del pandero, platillos y cuerdas punteadas de laúd, bandurrias y violines jugaban y danzaban mientras se divertian y cortejaban a la moza pretendida. Danzas y cortejos que no entendian ni de partituras ni de escuelas, fiesteros que por puro formalismo y algo más aceptaron el nombre de verdiales.

Sin embargo, no toda la oralidad de La Axarquía se reconoce dentro del marco de los verdiales. A pesar de quedar camuflados entre los desniveles del paisaje, encontramos dispersas por la comarca expresiones orales y formas de hacer fiesta similares bajo el nombre genérico de fandangos. Fandangos de Comares, Fandangos de Cómpeta, Fandangos de Güi, Maragatas, hermanos diseminados en el espacio que debemos tener en cuenta para comprender la oralidad y la musicalidad de la comarca.

De todos ellos serán los Fandangos de Comares, que tanto por sus caracteristicas como por su ubicación en el oriente de los Montes de Málaga, los que tomarán protagonismo y serán conocidos como verdiales $y$, de apellido, estilo Comares.

Al hablar de verdiales y fandangos, debemos referirnos a su elemento característico, esto es, su naturaleza oral, porque en todo su conjunto esta expresión fiestera es un elemento representativo de la oralidad de la comarca, tanto por su forma de transmisión y representación, como por su incidencia en la cultura de la comarca pasada y presente.

La oralidad ha sido una estrategia clave en la transmisión de valores, pautas, pertenencia, conocimiento, identidad y también de sentimientos. A raiz de ella, se han desarrollado herramientas diversas, concretadas en juegos, danzas, rimas, ritmos o melodias. Herramientas que permitian a la vez disfrutar, cortejar, evadirse, en definitiva, expresar sentimientos, definir comportamientos y relaciones sociales.

Será la escritura junto a nuevos contextos socio-económicos la que mermará y pondrá en tela de juicio la oralidad y con ello sus herramientas. Esto ha conllevado no solo su desprestigio sino también el de los sujetos que hoy continúan practicándola sin ha- berse sometido por completo a la escritura. Aquellos que aún hoy nos atrevemos a llamar con su beneplácito incultos.

Este proceso de transición incide en cada uno de los ámbitos de la sociedad reflejándose en el abandono paulatino de expresiones orales que definian las relaciones sociales y sus espacios. Si acercamos la mirada a La Axarquía y en concreto a los verdiales, los fandangos, las transformaciones se hacen más evidentes, a pesar de mostrarnos caminos diferentes. Veamos, pues, a qué nos referimos cuando hablamos de verdiales y fandangos para introducirnos en el proceso de transformación de la oralidad y las respuestas que genera.

Los fandangos y con ello los verdiales son expresiones orales musicalizadas que se reproducen cuando se pretende quebrar el tiempo productivo estipulado por el sistema agrario. Este contexto estipula formas de conducta y ocio a la vez que define una forma de oralidad. Sin embargo hoy estas expresiones orales se han alejado de su contexto y hablar de verdiales o fandangos es referirse exclusivamente a un estilo musical.

Existia un esquema común, coplas de seis versos octosilabos que acompañadas de percusión y cuerda eran danzadas en cortijos y lagares a la luz del candil creando un contexto ritual reconocido como fiesta. Dirigida por hombres, estos improvisaban coplas que hacian referencia generalmente al contexto territorial y a la mujer. Este esquema común se desarrollaba localmente determinado por su contexto territorial, mostrando variantes que es lo que nos lleva a hablar de Fandangos de Comares, Güi, Cómpeta o Alfarnate.

Para comprender las diferencias que existen entre las distintas producciones orales hay que observar el paisaje en el que se ubican. La Axarquia, a pesar del reconocimiento como ente geográfico común, no es uniforme y por ello tampoco establece relaciones similares internas ni externas. Por ello, las diferencias son palpables no solo en los nombres sino en su desarrollo y expresión.

Con este punto de partida, podemos hablar de dos marcos: el musical y el antropológico, que están estrechamente ligados uno con el otro. 

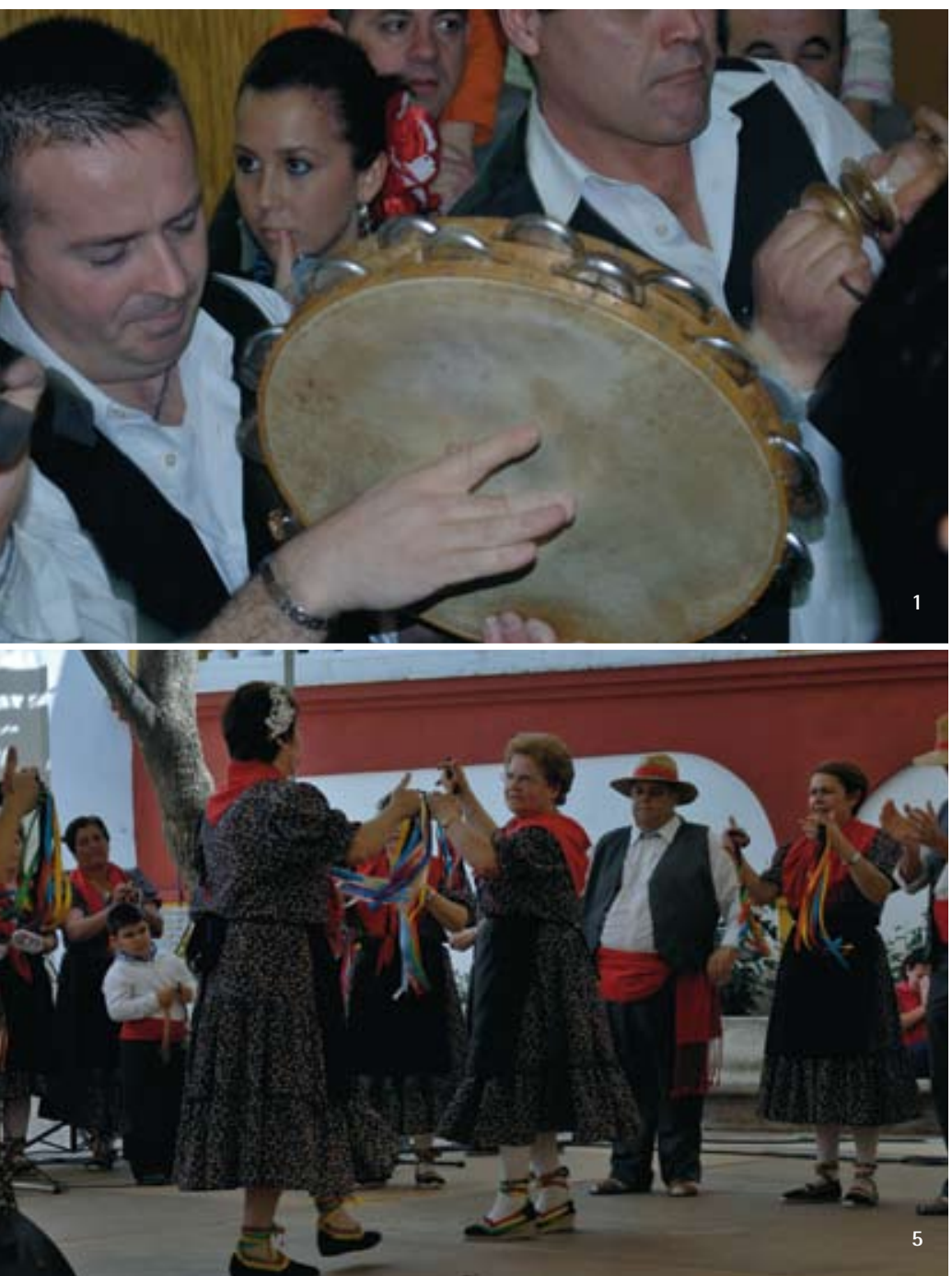

1. En Comares un pandero con platillos en el borde sustituyen a la botella de anís y al almirez a la hora de realizar la percusión, lo que lo acerca a los verdiales de Montes y Almogía. Foto: Marc Ballester Torrents, IAPH

5. El único grupo que hoy toca y baila los fandangos de Güi está en El Morche. Representación en la Fiesta del Nispero de Sayaolonga. Foto: Marc Ballester Torrents, IAPH

En el ámbito musical la incidencia de unos u otros instrumentos de percusión, el ritmo o los golpes en el baile nos permiten desgranar las ya anunciadas diferencias. En el caso de los verdiales del estilo Comares -o como los mismos intérpretes los llaman, fandangos de Comares- son los que le dan más relevancia a la cuerda tanto por puntearla como por la presencia del laúd y el violín. Este es uno de los elementos más significativos que diferencia a los fandangos de Güi o a los fandangos de Alfarnate a la vez que a los otros dos estilos de verdiales -Montes y Almogía. Paralelamente es común a todos ellos el uso de la percusión, palillos y platillos, mientras que la botella de anis y el almirez desaparecen en Comares para dar protagonismo a un pandero con platillos en el borde que lo acercan a los verdiales de los Montes y Almogía. Estos elementos inciden en el ritmo y donde en el Rio Güi son de cuatro rías y el pitá en Comares son tres rías y el pitá -lo que musicalmente se entiende como compás de tres por cuatro. El ritmo trasladado al baile lo hace más o menos frenético entre golpes y saltos adornados con las cintas de colores que cuelgan de los palillos. Sin embargo, el baile en pareja
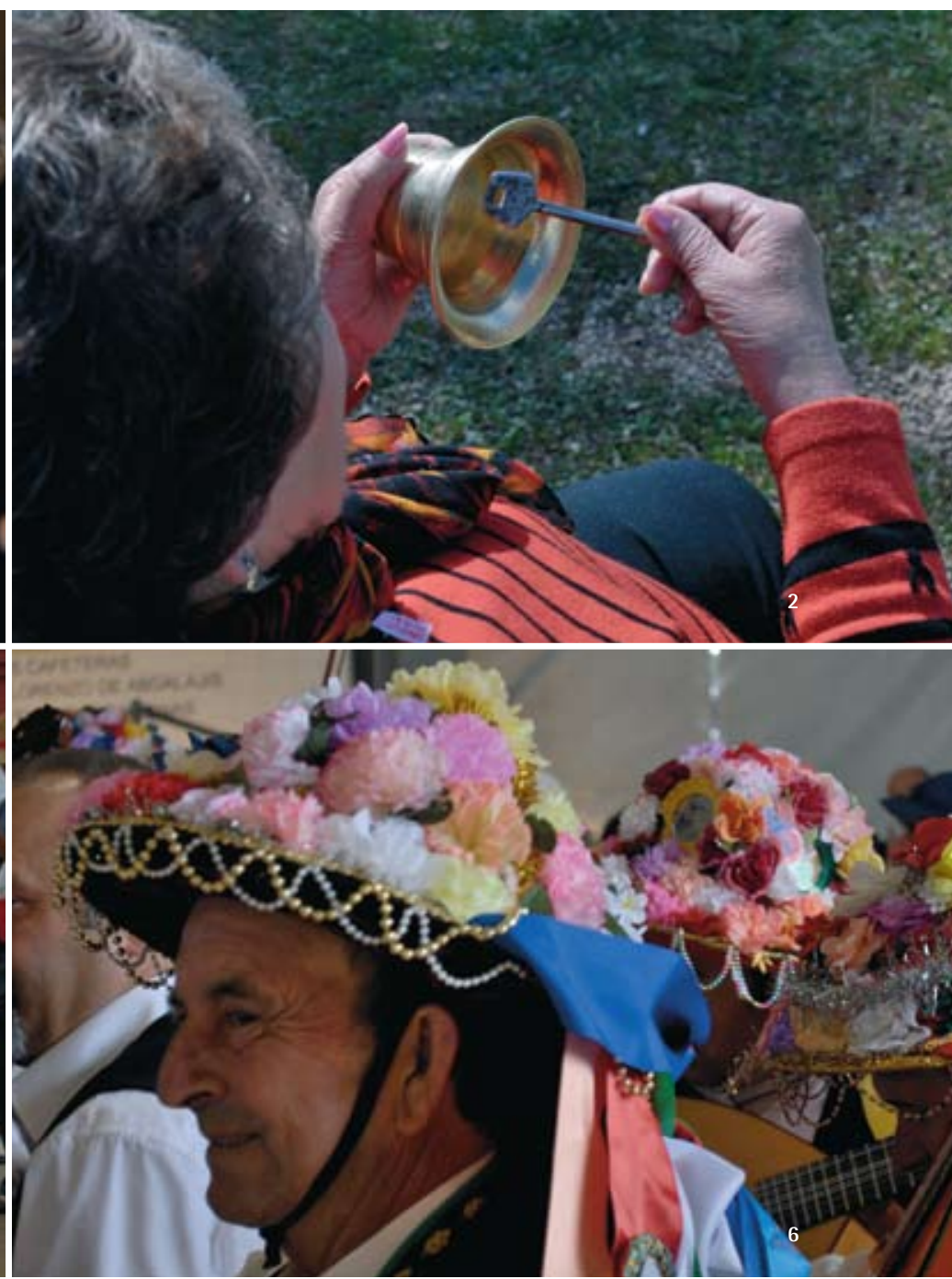

2 Almirez. Es un instrumento común en la comarca que se toca tanto en los fandangos de Güi como en Alfarnate y en otras expresiones musicales de la comarca, Maragatas o Pastorales. Foto: Marc Ballester Torrents, IAPH

6. El gorro con flores de plástico y espejos es un elemento representativo de los verdiales que se usa en el caso del estilo Comares exclusivamente el día de la fiesta mayor (28 de diciembre). Foto: Marc Ballester Torrents, IAPH

y trenzaillo -dos mujeres y un hombre- son comunes entre los diferentes estilos aunque varía el ritmo y con ello el golpe. Es por lo tanto el ritmo y con ello la incidencia de uno u otro instrumento el elemento diferenciador, aunque no por ello cambia el esquema melódico de los fandangos, que es el mismo.

En el marco antropológico conceptos como discurso, territorialidad, productividad nos permiten dar un paso más hacia la comprensión de sus similitudes y diferencias.

Si nos remitimos al análisis del discurso encontramos rasgos comunes tales como la identidad, la pertenencia, la exaltación y la evasión. El reconocimiento de lo territorial se expresa en coplas que remiten a Comares, Periana o al Rio Güi. Porque el "Balcón de La Axarquía" no es solo el lema publicitario de Comares sino que corre toda la comarca a voz de un fiestero de la Panda $1^{\circ}$ de Comares. 0 como cantaban en el oriente axarqueño cortejando a una mozuela: 

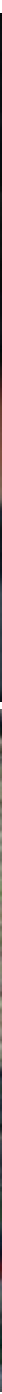

3. Actuación en un bar de la panda $1^{\circ}$ de Comares. Los músicos crean un círculo y dentro bailan quedando el público alrededor.

Foto: Marc Ballester Torrents, IAPH

7. Las cintas de colores son omnipresentes tanto en los verdiales como en los otros fandangos de La Axarquía. Con un sentido decorativo se cuelgan de palillos, panderos y platillos y complementan la estética fiestera.

Foto: Marc Ballester Torrents, IAPH

4. Laúd, violín y bandurria punteados son una de las características que definen el estilo Comares. Foto: Marc Ballester Torrents, IAPH

8. Hoy los fandangos de Alfarnate son exclusivamente representados por mujeres que los han pretendido recuperar a partir de una asociación. Foto: Marc Ballester Torrents, IAPH

De lo alto el rio Güi,

mira si vengo de lejos

de lo alto el rio Güi

por el Cortijo Pandela

hasta el arroyo Corchin

para ver a esta mozuela

Las coplas transmiten y definen el espacio en el que se ubican. Tómese como ejemplo, el caso de los fandangos de Güi. Estos fandangos, localizados al oriente de la comarca, se conocian antiguamente como Fandangos de Bentomiz por abarcar los campos que colindaban el castillo de Bentomiz -Sayalonga, Algarrobo, Lagos- y que hoy se han concentrado en el barranco del Rio Güi. Esta territorialidad define productos y en el caso de los verdiales está intrínseco el nombre. Al cantar De Verdiales vengo se definen no sólo un área territorial, los Montes de Málaga y La Axarquía oriental, sino también el producto que de ella se obtiene: la aceituna verdial.

Esta relación intrínseca entre expresión oral, territorialidad y productividad nos remite por lo tanto a la relación con el ámbito agrario que tenía la fiesta. Esta se desarrollaba principalmente en cortijos y lagares dentro de la temporalidad que marcaba el campo y siendo hasta no hace más de treinta años algo que extrañamente se acercaba a los núcleos urbanos. Los catetos habitan las aldeas, cortijos y montes donde las mismas condiciones de vida una vez más se vuelven ironía durante la fiesta:

Se me olvido la chaqueta

en lo hondo el rio Güi

se me olvido la chaqueta

tantos piojos tenia

que cuando por ella fui

iba ya por la Caleta"

Omnipresente en las coplas está el tema de la exaltación de la mujer. Ello no es extraño puesto que los fiesteros eran jóvenes que se juntaban para hacer fiesta y con ello cortejar a las mozuelas. 


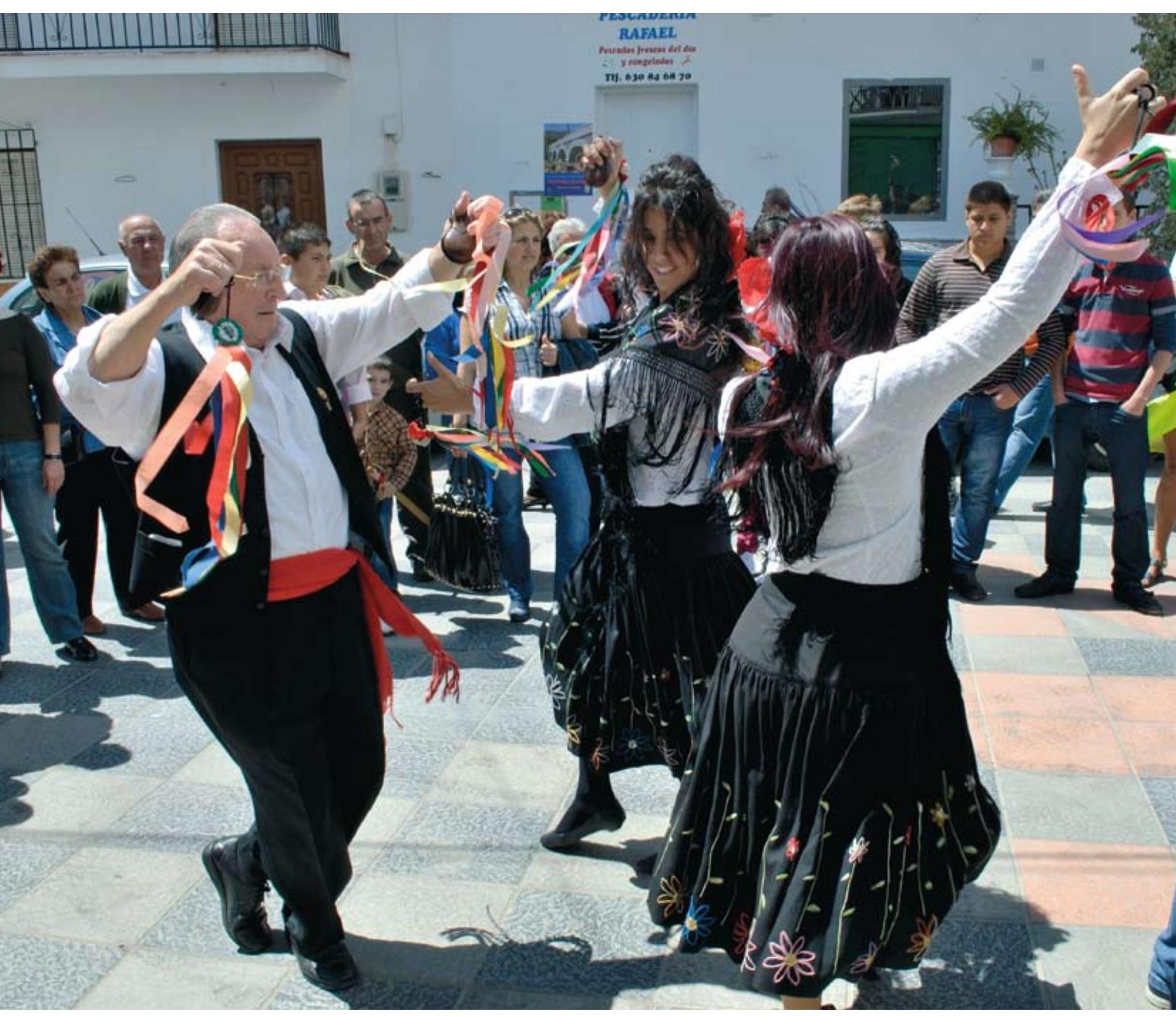

El trenzaíllo es una de las mudanzas de los verdiales donde bailan dos mujeres y un hombre. Foto: Marc Ballester Torrents, IAPH

El elemento más relevante en los fandangos de La Axarquía es la definición de una pertenencia que permite diferenciar uno de otro

Exaltaciones que a menudo remiten al territorio, definiendo con ello pertenencia y belleza.

Por lo tanto vemos cómo desde una percepción antropológica de los fandangos en La Axarquía, el elemento más relevante es la definición de una pertenencia que permite junto con lo musical diferenciar uno de otro. Sin embargo también nos permiten observar cómo el contexto en el que se desarrollan se define por un elemento común: están estrechamente ligados al ámbito agrario. Una vez definidos, la problemática se presenta cuando observamos el desarrollo que han tenido tanto los verdiales como los fandangos y su situación actual. Así como en la zona de Comares los verdiales están en un proceso de auge y reconocimiento, paralelamente en Cómpeta o el Güi estamos presenciando su desaparición. Veamos qué ha ocurrido con los verdiales, pretendiendo con ello comprender estos dos destinos tan opuestos, a pesar de ser expresiones que han tenido parte de desarrollo común.

Como punto de partida cabe dejar constancia que el territorio no entiende de jurisdicciones y que por ello los Montes de Málaga, cuna de los verdiales, se inmiscuyen en la comarca dibujando un territorio de contrastes delimitado por la vega del Vélez. Es pre- 
cisamente su presencia en los Montes lo que clasifica y define a los fiesteros de los cortijos de Comares, Cútar o el Borge como pandas de verdiales.

Pero es esta asimilación del concepto verdiales ha implicado que adquieran características que no son propias de los fiesteros del oriente del monte Santo Pítar. Al igual que con las características musicales, se ha dado un proceso de institucionalización y asentamiento de cada uno de los estilos, estética y contextualmente se ha creado un discurso unificador. El laúd y la bandurria punteados con un violín protagonista y con voz propia le dan su idiosincrasia que se acompaña de un ritmo más rápido marcado por el pandero. Un recuerdo, en algunas voces, de los tiempos en los que los campanarios eran minaretes.

La fijación de los tres estilos ha partido de las características de cada uno, sin embargo en lo estético, organizativo y con ello el imaginario colectivo de los verdiales ha tendido a homogenizar. Un primer elemento es su sistema organizativo. Presentados con el nombre de pandas - grupos de unas veinte personas donde diez tocan y el resto canta y danza-, tiene la figura del alcalde que dirige con una vara decorada con cintas de colores. Este sistema establecido hoy en todos los grupos surge de cuando era uno el que se encargaba de recoger a toda la panda para ir por los cortijos de fiesta y hacer rifas. Este sistema desconocido en La Axarquia hoy regula todas las pandas. Fiesteros igual, las fuentes orales reconocen haber adaptado esta opción al igual que la de ponerse el día de la Fiesta Mayor (28 de diciembre) el gorro bordado con flores de colores de plástico y pequeños espejos, sin el cual perderian puntos en la votación y que hoy se ha vuelto un elemento representativo de los fiesteros el día de su fiesta mayor.

Estos elementos han permitido que los fandangos de los montes de La Axarquía puedan reconocerse por completo como verdiales. Por lo tanto, a diferencia de los otros fandangos de la comarca, vemos cómo ha existido un proceso de adaptación y reglamentación.

Dentro del marco general de los verdiales, eventos como la Fiesta mayor -hoy aún en el Puerto la Torre (Málaga ciudad), antes en la Venta del Túnel (Montes de Málaga)- los diferentes festivales (Benagalbón, Comares) o encuentros como el del solsticio de verano en la Venta Cárdenas, han ayudado a afianzar no solo el estilo Comares sino el conjunto de los verdiales. Estos encuentros junto con las actuaciones pagadas en las diferentes fiestas patronales a lo largo de año nos empiezan a mostrar un poco el camino que han seguido.

Este camino viene definido por los cambios que han sufrido las zonas agrarias frente las urbanas: el cambio en el sistema productivo (y recientemente la cuestionable Politica Agraria Común de la Unión Europea y la incidencia del turismo y la construcción) los procesos migratorios (de la sierra al litoral, del ámbito rural al urbano -Málaga y Vélez- y estatal -Barcelona, Madrid-), las

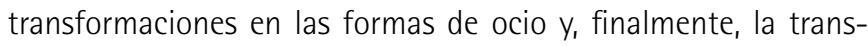
formación de la transmisión de saberes (el paso de una cultura principalmente oral a la implantación de un sistema educativo basado en la escritura). Al contrario que otros casos, los verdiales se han adaptado a este nuevo contexto, acercándose a las dinámicas urbanas (creación de escuelas, concursos, asociaciones, subvenciones, participación en la Feria o haciendo la Fiesta Mayor en el Puerto de la Torre). Esto ha favorecido al fortalecimiento de los verdiales como estilo musical pero ha ido en detrimento de todo el contexto que los definía, primando en casos concretos lo estético antes que el contexto fiestero.

Así pues, se observa cómo, a pesar de partir de una situación común, las respuestas han sido diversas. Los verdiales de Comares así como los fandangos de Güi, eran expresiones que se reproducian en el ámbito agrario, entre cortijos y lagares. Su abandono ha implicado transformaciones no sólo en el sistema productivo sino en la transmisión oral transgeneracional, tanto por el cambio en los núcleos familiares como por las formas de ocio o el sistema educativo. Arrimados a los verdiales, Comares llega a la ciudad (Comares hasta hace 15 años al no tener carretera directa a Vélez habia mirado siempre a Málaga) y se lleva a cabo un proceso de esencialización que se refleja en una clara definición de los tres estilos y de una estética común con variantes estilisticas teóricamente propias de cada zona (Almogía, Montes, Comares). Mientras, en el Güi (Algarrobo, el Morche, Sayalonga), las escuelas de baile enseñan sevillanas o malagueñas y la desaparición del contexto aqui si se vuelve una pieza clave.

El cambio del contexto obliga a modificar sus estrategias. La oralidad se vuelve escritura, las coplas extrañamente se improvisan, los maestros definen estilos que antes definían los ríos y partidos, las pandas llevan nombres de personas y no de pueblos (existe un caso en el estilo Almogía) y los verdiales abandonan los cortijos para ocupar escenarios o calles urbanas y permitir que aparezcan fiesteros a las puertas de una oficina. En este proceso de transformación -concepto clave para comprender la cultura- la oralidad, sus herramientas y sus estrategias, es la que se pone en entredicho.

Fandangos que ya quedan en la memoria de los supervivientes de un tiempo no tan lejano o verdiales en un escenario. Las transformaciones, característica inerte en la cultura, pueden llevarnos a veces a no comprender lo que vivimos. En la sociedad de lo efímero, lo caduco, se escriben coplas atrapándolas y congelándolas pretendiendo hacerlas eternas y contradiciendo unos fandangos, que surgen jugando con la ironía, lo sutil, la destreza del intérprete, acompañada de danzantes que se esquivan. Oralidad que provocaba riñas ficticias, o no tan ficticias, entre fiesteros por el amor pretendido, oralidad que marca códigos relacionales que hoy se pierden entre las paredes de una escuela y las tablas de un escenario.

Por ello en la sociedad de la escritura los verdiales se escriben hoy alejándose de un contexto sin saber aún si acabarán formando parte de una fotografía en el escenario del pasado folclorizado o continuarán transmitiendo y definiendo pertenecía y valores, hoy en la urbe, a ritmo de tres rías y el pitá. 


\section{Los alminares almohades de La Axarquía}

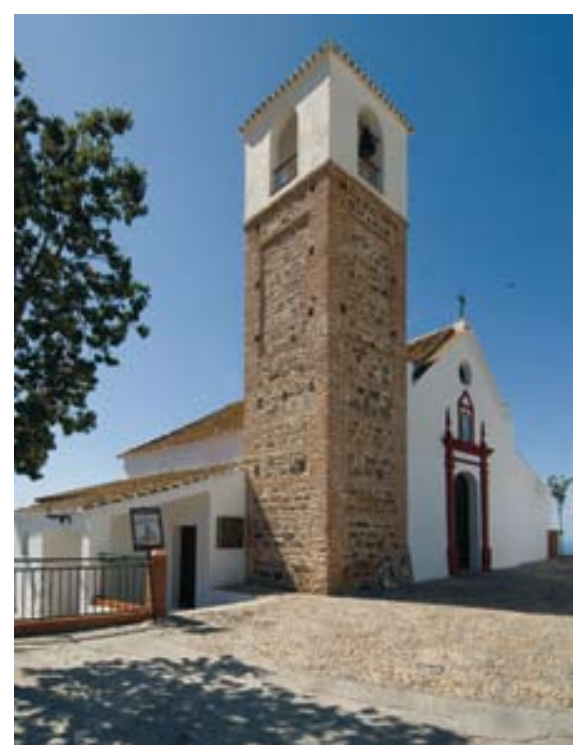

Corumbela. Foto: Juan Carlos Cazalla, IAPH

\section{Los alminares de La Axarquía, de inspiración merini y construidos en los siglos XIII-XIV, son únicos en toda Andalucía}

Los Almohades (literalmente, "los partidarios de la unicidad") surgieron como un movimiento religioso reformista, que aglutinó a diversas tribus montañesas del atlas norteafricano. Tras la muerte de su fundador emprendieron una rápida expansión y en el 1147 ocuparon Marrakech y Sevilla, a las que convirtieron en capitales de su imperio. Su dominio en la Peninsula Ibérica acabaria en la decisiva batalla de las Navas de Tolosa en 1212.

En La Axarquía, durante el siglo XII se había producido un despoblamiento generalizado de las poblaciones mozárabes autóctonas de las sierras de Bentomiz y Tejeda-Almijara, debido a que fueron expulsados o trasladados. Tal situación fue aprovechada para introducirse grupos beréberes norteafricanos, como fueron los Masmudas, llegados con los ejércitos almohades, que se establecieron desde Canillas de Aceituno hasta Nerja. También en otras áreas de La Axarquia se instalaron otros grupos como los Gomeres que tuvieron una cierta implantación en la ciudad de Vélez.

La influencia de estos grupos durante los siglos XIII y

$\mathrm{XV}$ fue importante en esta zona cuya huella se puede rastrear en los singulares alminares, hoy dia torrescampanarios, de las localidades de Vélez-Málaga, Daimalos, Corumbela, Árchez y Salares, lo mismo que Arenas que fue destruido. Estos alminares son típicos minaretes de los siglos XIII-XIV, de inspiración merini, únicos en toda La Axarquia y Andalucia. La ascendiente africana es determinante, donde la práctica totalidad de sus fachadas se decoran, dejando libres las esquinas, según modelos similares de los alminares meriníes de Tremencén, edificado en 1231, y de Túnez, de 1353. Son de proporciones armoniosas, su altura es cuatro veces la de uno de sus lados, y su plan decorativo se desarrolla a partir del segundo cuerpo, con rectángulos rehundidos en los que suelen aparecer los llamados paños de sebka, cintas horizontes de azulejos, franja de arcos apuntados, etc.

La mezquita ocupa el lugar central en la arquitectura islámica y representa el símbolo de la fe a la que se sirve. Este elemento simbólico fue comprendido por los musulmanes en una etapa temprana, y desempeñó un papel importante en la creación de adecuados signos visibles para el edificio: el alminar, la quibla y el Mihrab. Desde lo alto del alminar (torre de la mezquita) el muecin llama a los musulmanes a la oración, es el signo más prominente de la mezquita. Los alminares españoles y norteafricanos, que comparten la torre cuadrada tradicional de los sirios, están decorados con paneles de motivos ornamentales dispuestos en torno a ventanas geminadas.

Por las fuentes castellanas sabemos que en la zona meridional de la ciudad medieval de Vélez existía un amplio barrio conocido como el Arrabal de Los Gomeres, donde se habia instalado este grupo beréber norteafricano. Este sector urbano quedaba com-

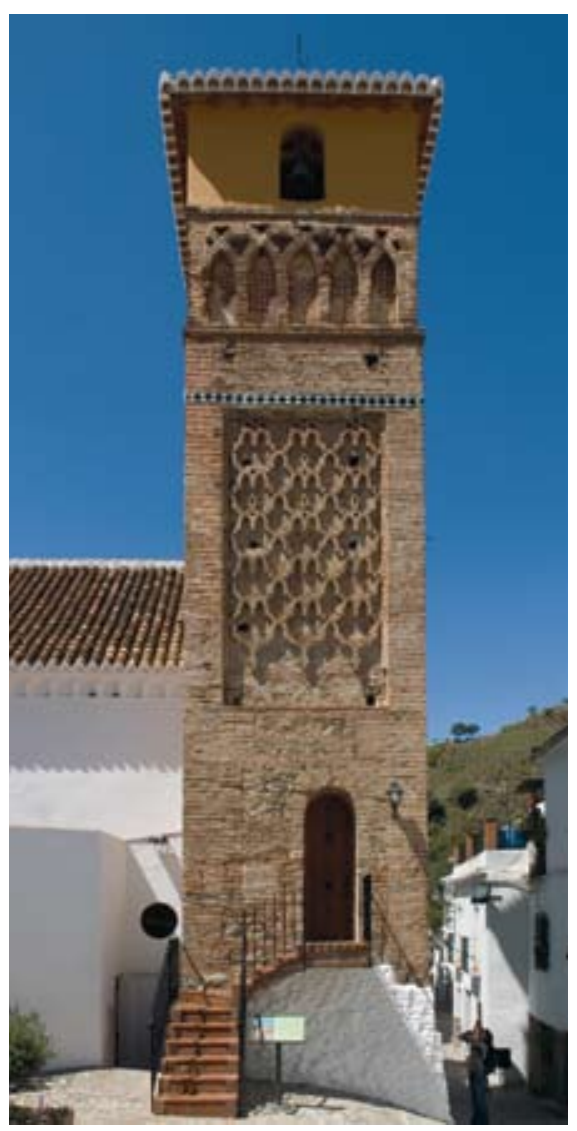

Árchez. Foto: Juan Carlos Cazalla, IAPH prendido por los actuales barrios de San Francisco y La Gloria, y estaba vinculado especialmente con distintos espacios de carácter cultual, caso de un ribat (que se ubicaba donde se encuentra la actual Ermita de Ntra. Sra. de Los Remedios) y el cementerio de la ciudad musulmana que tenía próximo una mezquita (que se corresponderia con la iglesia del convento franciscano de Santiago), y otras mezquitas menores.

El cementerio musulmán se extendia desde el convento franciscano hasta las plazas de la Concepción y Capuchinos del actual casco urbano veleño. La mezquita más importante de este barrio, que estaba próxima a la necrópolis, se encontraba en la actual iglesia del Convento de Santiago, de la que ha quedado como testimonio su antiguo alminar que fue convertido en torre-campanario y que se encuentra a los pies de iglesia. En los recientes trabajos de rehabilitación del convento se han descubierto diferentes sectores del alminar con la típica decoración de paños de sebka, destacando una amplia zona de la cara norte y pequeños segmentos en los lados sur y oeste, que estaban muy dañados por las obras del convento en el siglo XVI. Al norte se pudo constatar la presencia de la parte media y alta de un gran rectángulo rehundido, decorado con paño de sebka que se realiza por medio de ladrillos recortados, que forman rombos mixtilineos y rematados en su parte superior por piezas circulares, conservándose restos de pintura mural de color rojo almagra con temas vegetales. Ha sido una novedad descubrir que los huecos de las piezas circulares se rellenaban con azulejos de color verde y negro, como también ha sido una sorpresa documentar que todo el rectángulo quedaba delimitado al exterior por una línea de piezas rectangulares de azulejos de color verde.

También ha sido descubierto con las obras de rehabilitación el acceso al alminar, que se encontraba en su lado oeste. Su interior cuenta con un machón central en torno al cual se desarrolla una escalera.

Este alminar guarda estrecha relación con los de Árchez y Salares, pero habrá que esperar a la definitiva rehabilitación del campanario para poder descubrir más zonas de este antiguo alminar y tener un mejor conocimiento del mismo. Para poder contemplar los paños de sebka, que se encuentran en un pequeño patio interior de la primera planta, deberán solicitar a los franciscanos del convento permiso para su acceso.

Inmersos en los dominios de la Sierra de Bentomiz, al noroeste de Vélez, encontramos Daimalos donde haIlaremos un magnífico alminar, convertido en el siglo $\mathrm{XVI}$ en torre-campanario de su Iglesia Ntra. Sra. de la Concepción, y que está considerado como el más arcaico de todos. Consta de cuatro cuerpos, si bien el último es añadido como cuerpo de campanas. Su primer cuerpo es el más ancho y alto, carece de decoración y tiene unos pequeños huecos para permitir una mínima iluminación. El segundo cuerpo, que está 


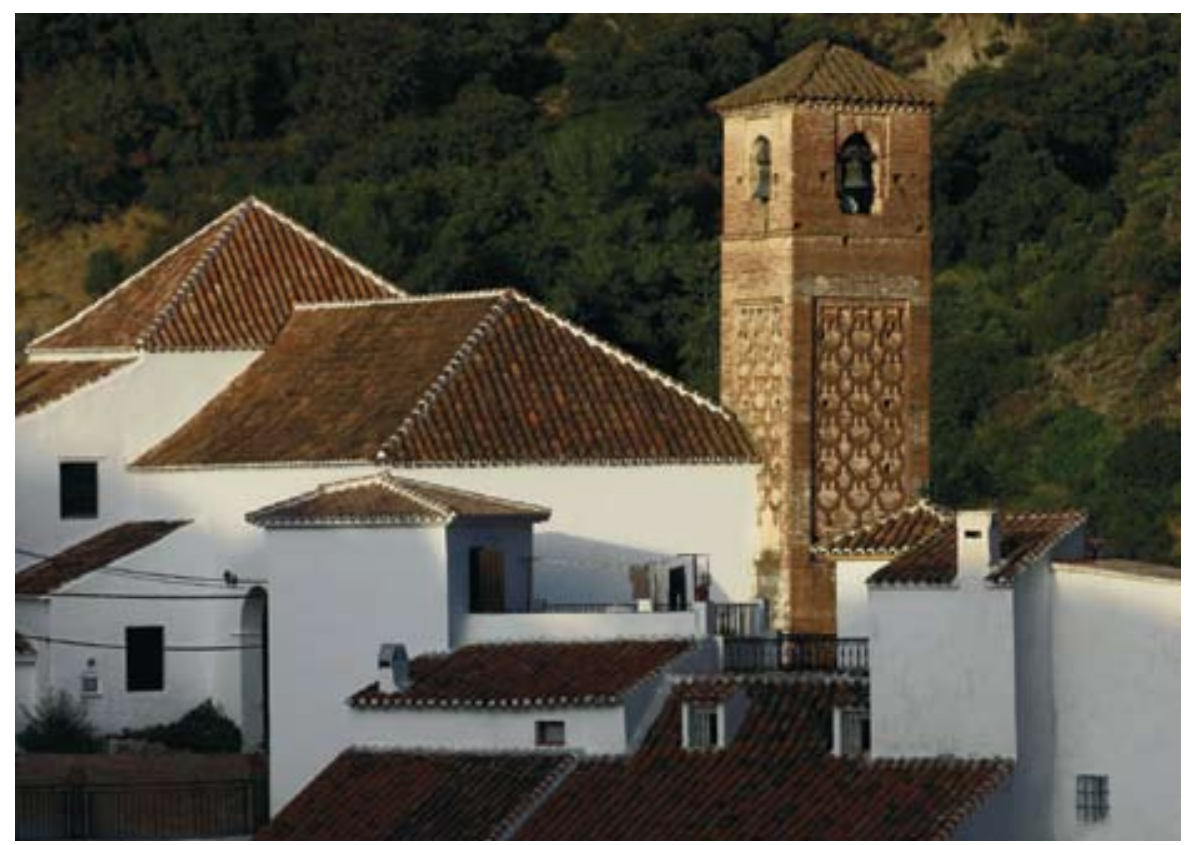

Salares. Foto: Miguel Ángel Blanco de la Rubia

separado del anterior por una linea de imposta, es el único que presenta decoración en su fachada mediante cuatro arcos ciegos apuntados. El tercer cuerpo, igualmente separado por otra línea de imposta, es liso y carece de ornato. En el interior encontramos una angosta escalera, que se dispone de forma radial sobre un machón central macizo, que solo permite el paso a una persona.

A varios kilómetros de Daimalos se encuentra Corumbela, cuya iglesia esta consagrada a la advocación de San Pedro y que se encuentra a la salida del pueblo en dirección a Árchez. En el exterior, en el lateral derecho del templo, se alza el alminar realizado en mampostería de gruesas piedras alternadas por hiladas de ladrillo, con estructura de prisma rectangular. Este se relaciona con el de Árchez, aunque es de menor importancia. Ha llegado hasta nosotros muy mutilado debido a una notable transformación externa al adaptarse como torre-campanario. En el cuerpo central aparece, en cada lado del alminar, un rectángulo rehundido que debió albergar los paños de sebka con sus rombos mixtilíneos, no conservándose ninguno. El siguiente cuerpo queda separado por una línea de imposta, modificado para la realización del campanario, presenta una corta franja horizontal donde se destaca la presencia de una serie de arcos apuntados, que se cegaron en época cristiana, que también pueden observarse en su lado interno. En el interior de la torre encontramos las escaleras alrededor de un machón central con bóvedas de medio cañón escalonadas, ubicándose el ladrillo de modo radial y horizontalmente, aunque se encuentran tramos muy mal conservados, incluso se pueden encontrar vigas y cañas con yeso.

A unos $4 \mathrm{~km}$ al noroeste de Corumbela encontramos el pueblo de Árchez, donde descubriremos un hermoso alminar muy bien conservado, que se localiza en la cabecera de la Iglesia de Ntra. Sra. de la Encarnación al que se accede desde el exterior, desde una pequeña puerta que está a unos 1,7 m del suelo, quedando por encima del original. Tiene unas proporciones bastante armónicas, con una altura de $15 \mathrm{~m}$ y 3,64 m de lado. En el interior se dispone un cuadrado macizo o machón de 1,07 m de lado en torno al cual se desarrolla una escalera cubierta con bóveda escalonada de medio cañón.

Se realiza en mamposteria y ladrillo, y se compone de cuatro cuerpos. En el segundo de ellos, que es el más amplio, se decoran sus cuatro lados con rectángulos rehundidos adornos (¿adornados?) con paños de sebka, por medio de ladrillos recortados que forman rombos mixtilíneos, entre los que se conservan restos de pinturas originales de color rojo almagra. Comenzaba la parte inferior de los paños con unas pequeñas columnas o arcos, hoy dia desaparecidas, mientras que su parte superior queda rematada por piezas circulares. Por encima de los rectángulos se crea una franja horizontal de azulejos policromos en blanco con rombos azules que recorre todo los lados de la torre. El tercer cuerpo está caracterizado por una franja horizontal de cinco arcos ciegos de herradura apuntados entrelazados, donde también se conservan

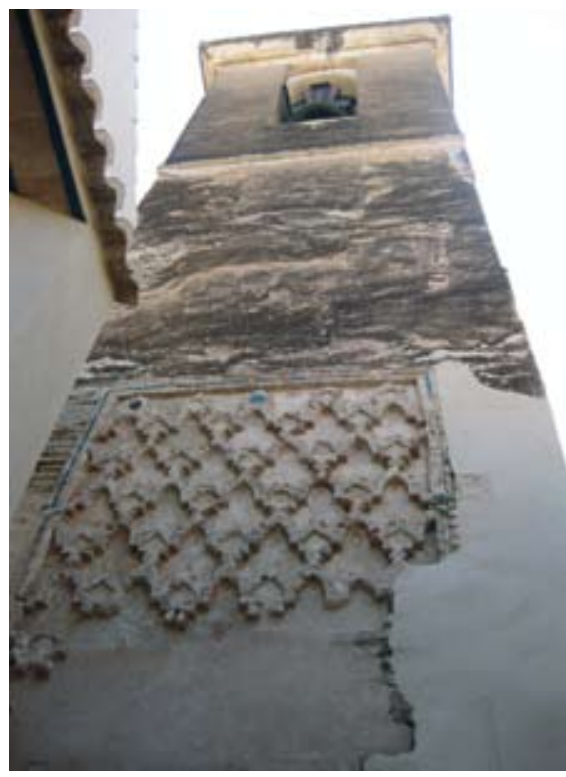

Vélez-Málaga. Convento de San Francisco. Foto: Emilio Martín Córdoba

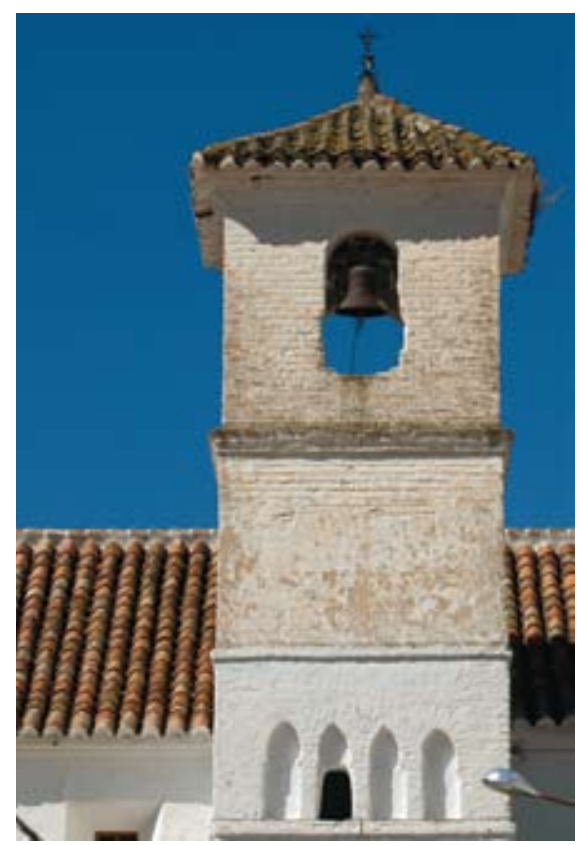

Daimalos. Foto: Juan Carlos Cazalla, IAPH

restos de pintura original relacionados con rombos, cuadrados y dameros. El último cuerpo, donde estaba la terraza del alminar, fue eliminado para albergar las campanas y cubierto con tejado a cuatro aguas.

La localidad de Salares, que es uno de los pocos pueblos de La Axarquia que ha conservado parte de su caserio tradicional, presenta un alminar que domina el paisaje urbano, localizado en el lado derecho de la actual Iglesia de Santa Ana, definido por una estructura de prisma rectangular. Mantiene una estrecha relación con el de Árchez, aunque con unas dimensiones algo menores, pues su altura es de unos $12 \mathrm{~m}$ y su lado es de 3,5m. A igual que éste, su acceso se realiza desde el exterior con una entrada que queda más elevada que la original. Al igual que los anteriores, el interior cuenta con un pilar macizo central, de unos 0,9 $\mathrm{m}$ de ancho, sobre el que se dispone una escalera con bóveda de medio cañón escalonada con aristas en los extremos.

Está realizado en ladrillo y mampostería, componiéndose de tres cuerpos, el primero no presenta ningún tipo de decoración, si bien queda rematado por un rectángulo horizontal de azulejos donde se disponen dos filas de rombos azules sobre fondo blanco. El segundo cuerpo, más amplio en longitud, se compone de rectángulos rehundidos con paños de sebka en los cuatro lados, compuestos por rombos mixtilíneos realizados por ladrillos recortados, que dejan las esquinas libres sin decoración. En la parte inferior de los rombos mixtilíneos han desaparecido unas pequeñas columnas, igual que ocurre en Árchez, y no ha quedado ningún rastro de pintura mural. El último cuerpo, añadido en época cristiana para albergar las campanas, comienza a partir de una imposta y queda cubierto por un tejado a cuatro aguas. Adentrándonos en el patio oeste de la iglesia nos encontraremos con los restos de pilares y arcos apuntados, que se corresponden con la antigua mezquita.

Emilio Martín Córdoba

Arqueólogo 
AGUILAR GARCíA, María Dolores. Málaga mudéjar : arquitectura religiosa y civil. Málaga : Universidad, 1979

AUBET, María Eugenia. Los fenicios en Málaga. Málaga : Servicio de publicaciones de la Universidad de Málaga, [1998]

AUBET, María Eugenia. Tiro y las colonias fenicias de Occidente. Barcelona : Crítica, 1994 (1997 reimp.)

AUBET, María Eugenia... [et al.]. Cerro de/ Villar : el asentamiento fenicio en la desembocadura del rio Guadalhorce y su interacción con el hinterland. [Sevilla] : Junta de Andalucia, Consejería de Cultura, Empresa Pública de Gestión de Programas Culturales, 1999*

BERLANGA FERNÁNDEZ, Miguel Ángel. Bailes de candil andaluces y "fiesta" de los verdiales otra visión de los fandangos. Málaga : Centro de Ediciones de la Diputación de Málaga, 2000

CAMACHO MARTÍNEZ, Rosario (dirección). Guía artística de Málaga y su provincia. Sevilla : Fundación José Manuel Lara, 2006, 2 vol*

HARVEY, D.; SMITH, N. Capital financiero, propiedad inmobiliaria y cultura. Bellaterra (Barcelona) : Universitat Autònoma de Barcelona ; Barcelona : Museu d'Art Contemporani, 2005 [citado por el autor en el artículo "Turismo y cultura"]

\section{JORNADAS EUROPEAS DE PATRIMONIO (10.}

2000. Andalucía). El mudéjar en Andalucía. Sevilla : Junta de Andalucia, Consejeria de Cultura : Empresa Pública de Gestión de Programas Culturales, 2000*

LÓPEZ GUZMÁN, Rafael. Arquitectura mudéjar : del sincretismo medieval a las alternativas hispanoamericanas. Madrid : Cátedra, 2005*
LÓPEZ SANFELIÚ, M.J.; LÓPEZ INFANTE, M.I.; CANALEJO RAYA, J.E. [et al.]. La pasa moscatel en la comarca de la Axarquía. Alimentación, equipos y tecnología, Año 18, n 5, 1999, p. 95-100

MACCANNELL, Dean. Lugares de encuentro vacios. Barcelona : Melusina, 2007 [citado por el autor en el artículo "Turismo y cultura"]

MANDLY ROBLES, Antonio. "Echar un revezo" : cultura, razón común en Andalucía. Málaga : Servicio de Publicaciones, Diputación Provincial, [1996]

MARTín CÓRDOBA, Emilio; RECIO RUIZ, Ángel. Los fenicios en la costa de Vélez-Málaga. VélezMálaga : Axarmedia, 2002

MEDINA GUERRA, Antonia M; AYALA CASTRO, Marta C. Él léxico de las pasas en la Axarquia malagueña. En : Lingüística para el siglo XXI : III Congreso de Lingüística general, Salamanca, 1998. Salamanca : Ediciones de la Universidad de Salamanca, 1999, 2 vol., p. 209-216

EI PATRIMONIO histórico como recurso para el conocimiento de la Historia. Vol.8, Itinerarios por el conjunto histórico de Vélez-Málaga. [Sevilla] : Consejería de Educación y Ciencia : Consejería de Cultura : Fundación El Monte, D.L. 1999*

PLAN de Ordenación del Territorio Costa del Sol oriental-Axarquía / Consejería de Obras Públicas y Transportes, Secretaría General de Ordenación del Territorio y Urbanismo. Sevilla : Consejeria de Obras Públicas y Transportes, 2006

PRADOS MARTÍNEZ, Fernando. Los fenicios : del monte Libano a las columnas de Hércules. Madrid : Marcial Pons Historia, 2007

RODRÍGUEZ MARÍN, Francisco. Patrimonio y ciudad : patrimonio industrial azucarero en la Axarquia : entre el olvido y la puesta en valor. Isla de Arriarán : revista cultural y cientifica, no 28, 2006, p. 7-38
ROMERO ESTEO, Miguel. Los verdiales : raíces del folklore andaluz. Málaga : Sarriá, 2002

ROMERO ESTEO, Miguel. Una reliquia demasiado arcaica : Ios verdiales malagueños. Narria : estudios de artes y costumbres populares, n 73-74, 1996*

RUBIO DÍAZ, A.; SERRANO MUÑOZ, E. La

ordenación del territorio en la provincia de Málaga. En : Aurioles, J. y Parejo, A. La economía de la provincia de Málaga. Málaga : Fundación Cajamar, 2007, p. 261-353

RUEDA, Fernando. Por los caminos de la Axarquía : 15 itinerarios para recorrer pueblos y parajes de la comarca de la Axarquía. Málaga : Airón, 2006

RUIZ GARCÍA, P. La Axarquía, tierra de azúcar : cincuenta y dos documentos históricos. VélezMálaga : Asukaria Mediterránea, 2000

SAGRA, Ramón de la. Informe sobre el cultivo de la caña y la fabricación del azúcar en las costas de Andalucía , presentando la empresa azucarera peninsular. Granada : Asukaria Mediterránea, 1999 Reprod. facs. de la ed. de: Madrid: Imprenta del Colegio de sordo-mudos y ciegos, 1845

\section{SANTIAGO RAMOS, A.; GUZMÁN VALDIVIA, A.} Axarquía, patrimonio industrial. En : Descubre la Axarquía. Materiales para el estudio de la Axarquía, vol. VI. Benamocarra (Málaga) : Centro de Desarrollo Rural de la Axarquía. CEDER-Axarquía, D.L. 2007

TIEMPOS de púrpura. Málaga antigua y antigüedades hispanas. Mainake, n XXVIII, 2006, Tomo I

Nota: Bibliografia resumida de la sección. Para una mayor informació puede consultar el catálogo online (http: www.juntadeandalucia. es/cultura/iaph/absys/abwebp.exe/) de la Biblioteca del IAPH. Las publicaciones marcadas con asterisco $\left.{ }^{*}\right)$ se encuentran disponibles para su consulta en la Biblioteca del IAPH

\section{En la web}

\section{DIPUTACIÓN PROVINCIAL DE} MÁLAGA

\section{www.malaga.es}

La web oficial de la Diputación Provincial de Málaga ofrece fichas descriptivas de los municipios de la comarca de La Axarquía con información geográfica, demográfica, artesanía, fiestas, imágenes, rutas, mapas de localización y monumentos.

CENTRO DE DESARROLLO RURAL DE LA AXAROUÍA (CEDER - AXAROUÍA) www.cederaxarquia.org

Asociación cuya finalidad principal es el desarrollo local y rural de la comarca de La Axarquía. La web ofrece datos generales de la comarca y los municipios que la conforman a través de un mapa interactivo. Rutas por la comarca, proyectos de cooperación en el ámbito del turismo cultural, un interesante vuelo virtual por La Axarquía en $3 \mathrm{D}$ son algunas de las opciones que se puede visitar en este sitio web.

\section{FEDERACIÓN DE PANDAS DE VERDIALES}

www.fiestadeverdiales.com

Organización sin ánimo de lucro dedicada a fomentar, entre otros fines, la enseñanza y difusión de los verdiales. El sitio web ofrece una gran variedad de recursos sobre esta tipología de cante y baile: aproximación a sus orígenes, pandas y estilos, concursos y festivales, escuelas de verdiales, ermitas verdialeras, letras y coplas, asociaciones y peñas, además de noticias relacionadas.

\section{MUSEO DE LA PASA (ALMÁCHAR)} www.almachar.es

La web oficial del Ayuntamiento de Almáchar presenta en el apartado $\mathrm{Mu}$ seos información sobre el Museo de la Pasa, con datos de su localización, historia, colección e imágenes.

\section{VERDIALES DE MÁLAGA}

\section{www.verdiales.org}

Este sitio web permite la descarga en MP3 de los diferentes estilos de verdiales así como una descripción de sus características principales. Además presenta videos de festivales que se celebran en municipios de la comarca.

\section{FUNDACIÓN MARÍA ZAMBRANO}

www. fundacionmariazambrano.org

Todas las actividades culturales relacionadas con la pensadora Maria Zambrano están disponibles en la web de esta fundación cultural privada: congresos, seminarios, actos conmemorativos junto a los recursos que ofrece la biblioteca de la Fundación entre los que destaca la publicación Antígona. 
AGUILAR GARCíA, María Dolores. Málaga mudéjar : arquitectura religiosa y civil. Málaga : Universidad, 1979

AUBET, María Eugenia. Los fenicios en Málaga. Málaga : Servicio de publicaciones de la Universidad de Málaga, [1998]

AUBET, María Eugenia. Tiro y las colonias fenicias de Occidente. Barcelona : Crítica, 1994 (1997 reimp.)

AUBET, María Eugenia... [et al.]. Cerro de/ Villar : el asentamiento fenicio en la desembocadura del rio Guadalhorce y su interacción con el hinterland. [Sevilla] : Junta de Andalucia, Consejería de Cultura, Empresa Pública de Gestión de Programas Culturales, 1999*

BERLANGA FERNÁNDEZ, Miguel Ángel. Bailes de candil andaluces y "fiesta" de los verdiales otra visión de los fandangos. Málaga : Centro de Ediciones de la Diputación de Málaga, 2000

CAMACHO MARTÍNEZ, Rosario (dirección). Guía artística de Málaga y su provincia. Sevilla : Fundación José Manuel Lara, 2006, 2 vol*

HARVEY, D.; SMITH, N. Capital financiero, propiedad inmobiliaria y cultura. Bellaterra (Barcelona) : Universitat Autònoma de Barcelona ; Barcelona : Museu d'Art Contemporani, 2005 [citado por el autor en el artículo "Turismo y cultura"]

\section{JORNADAS EUROPEAS DE PATRIMONIO (10.}

2000. Andalucía). El mudéjar en Andalucía. Sevilla : Junta de Andalucia, Consejeria de Cultura : Empresa Pública de Gestión de Programas Culturales, 2000*

LÓPEZ GUZMÁN, Rafael. Arquitectura mudéjar : del sincretismo medieval a las alternativas hispanoamericanas. Madrid : Cátedra, 2005*
LÓPEZ SANFELIÚ, M.J.; LÓPEZ INFANTE, M.I.; CANALEJO RAYA, J.E. [et al.]. La pasa moscatel en la comarca de la Axarquía. Alimentación, equipos y tecnología, Año 18, n 5, 1999, p. 95-100

MACCANNELL, Dean. Lugares de encuentro vacios. Barcelona : Melusina, 2007 [citado por el autor en el artículo "Turismo y cultura"]

MANDLY ROBLES, Antonio. "Echar un revezo" : cultura, razón común en Andalucía. Málaga : Servicio de Publicaciones, Diputación Provincial, [1996]

MARTín CÓRDOBA, Emilio; RECIO RUIZ, Ángel. Los fenicios en la costa de Vélez-Málaga. VélezMálaga : Axarmedia, 2002

MEDINA GUERRA, Antonia M; AYALA CASTRO, Marta C. Él léxico de las pasas en la Axarquia malagueña. En : Lingüística para el siglo XXI : III Congreso de Lingüística general, Salamanca, 1998. Salamanca : Ediciones de la Universidad de Salamanca, 1999, 2 vol., p. 209-216

EI PATRIMONIO histórico como recurso para el conocimiento de la Historia. Vol.8, Itinerarios por el conjunto histórico de Vélez-Málaga. [Sevilla] : Consejería de Educación y Ciencia : Consejería de Cultura : Fundación El Monte, D.L. 1999*

PLAN de Ordenación del Territorio Costa del Sol oriental-Axarquía / Consejería de Obras Públicas y Transportes, Secretaría General de Ordenación del Territorio y Urbanismo. Sevilla : Consejeria de Obras Públicas y Transportes, 2006

PRADOS MARTÍNEZ, Fernando. Los fenicios : del monte Libano a las columnas de Hércules. Madrid : Marcial Pons Historia, 2007

RODRÍGUEZ MARÍN, Francisco. Patrimonio y ciudad : patrimonio industrial azucarero en la Axarquia : entre el olvido y la puesta en valor. Isla de Arriarán : revista cultural y cientifica, no 28, 2006, p. 7-38
ROMERO ESTEO, Miguel. Los verdiales : raíces del folklore andaluz. Málaga : Sarriá, 2002

ROMERO ESTEO, Miguel. Una reliquia demasiado arcaica : Ios verdiales malagueños. Narria : estudios de artes y costumbres populares, n 73-74, 1996*

RUBIO DÍAZ, A.; SERRANO MUÑOZ, E. La

ordenación del territorio en la provincia de Málaga. En : Aurioles, J. y Parejo, A. La economía de la provincia de Málaga. Málaga : Fundación Cajamar, 2007, p. 261-353

RUEDA, Fernando. Por los caminos de la Axarquía : 15 itinerarios para recorrer pueblos y parajes de la comarca de la Axarquía. Málaga : Airón, 2006

RUIZ GARCÍA, P. La Axarquía, tierra de azúcar : cincuenta y dos documentos históricos. VélezMálaga : Asukaria Mediterránea, 2000

SAGRA, Ramón de la. Informe sobre el cultivo de la caña y la fabricación del azúcar en las costas de Andalucía , presentando la empresa azucarera peninsular. Granada : Asukaria Mediterránea, 1999 Reprod. facs. de la ed. de: Madrid: Imprenta del Colegio de sordo-mudos y ciegos, 1845

\section{SANTIAGO RAMOS, A.; GUZMÁN VALDIVIA, A.} Axarquía, patrimonio industrial. En : Descubre la Axarquía. Materiales para el estudio de la Axarquía, vol. VI. Benamocarra (Málaga) : Centro de Desarrollo Rural de la Axarquía. CEDER-Axarquía, D.L. 2007

TIEMPOS de púrpura. Málaga antigua y antigüedades hispanas. Mainake, n XXVIII, 2006, Tomo I

Nota: Bibliografia resumida de la sección. Para una mayor informació puede consultar el catálogo online (http: www.juntadeandalucia. es/cultura/iaph/absys/abwebp.exe/) de la Biblioteca del IAPH. Las publicaciones marcadas con asterisco $\left.{ }^{*}\right)$ se encuentran disponibles para su consulta en la Biblioteca del IAPH

\section{En la web}

\section{DIPUTACIÓN PROVINCIAL DE} MÁLAGA

\section{www.malaga.es}

La web oficial de la Diputación Provincial de Málaga ofrece fichas descriptivas de los municipios de la comarca de La Axarquía con información geográfica, demográfica, artesanía, fiestas, imágenes, rutas, mapas de localización y monumentos.

CENTRO DE DESARROLLO RURAL DE LA AXAROUÍA (CEDER - AXAROUÍA) www.cederaxarquia.org

Asociación cuya finalidad principal es el desarrollo local y rural de la comarca de La Axarquía. La web ofrece datos generales de la comarca y los municipios que la conforman a través de un mapa interactivo. Rutas por la comarca, proyectos de cooperación en el ámbito del turismo cultural, un interesante vuelo virtual por La Axarquía en $3 \mathrm{D}$ son algunas de las opciones que se puede visitar en este sitio web.

\section{FEDERACIÓN DE PANDAS DE VERDIALES}

www.fiestadeverdiales.com

Organización sin ánimo de lucro dedicada a fomentar, entre otros fines, la enseñanza y difusión de los verdiales. El sitio web ofrece una gran variedad de recursos sobre esta tipología de cante y baile: aproximación a sus orígenes, pandas y estilos, concursos y festivales, escuelas de verdiales, ermitas verdialeras, letras y coplas, asociaciones y peñas, además de noticias relacionadas.

\section{MUSEO DE LA PASA (ALMÁCHAR)} www.almachar.es

La web oficial del Ayuntamiento de Almáchar presenta en el apartado $\mathrm{Mu}$ seos información sobre el Museo de la Pasa, con datos de su localización, historia, colección e imágenes.

\section{VERDIALES DE MÁLAGA}

\section{www.verdiales.org}

Este sitio web permite la descarga en MP3 de los diferentes estilos de verdiales así como una descripción de sus características principales. Además presenta videos de festivales que se celebran en municipios de la comarca.

\section{FUNDACIÓN MARÍA ZAMBRANO}

www. fundacionmariazambrano.org

Todas las actividades culturales relacionadas con la pensadora Maria Zambrano están disponibles en la web de esta fundación cultural privada: congresos, seminarios, actos conmemorativos junto a los recursos que ofrece la biblioteca de la Fundación entre los que destaca la publicación Antígona. 